ISSN 2215-227X

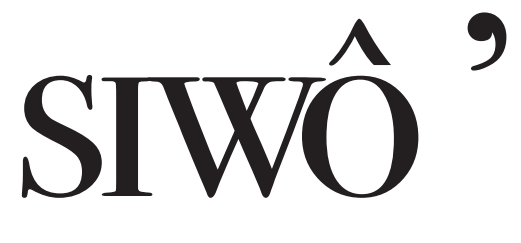

\title{
Revista de Teología
}

Volumen 10, Número 2

2016 


\section{ESCUELA ECUMÉNICA}

MET. Diego Soto (Director)

MET. Auxiliadora Montoya (Directora Esc. Ecum.)

Dr. Juan Manuel Fajardo Andrade

Dr. Jonathan Pimentel (Editor)

\section{EDITORIAL SEBILA}

M.Sc. Ruth Mooney (Directora)

M.Sc. Mireya Baltodano Arroliga

Dr. José Enrique Ramírez

\title{
CONSEJO ASESOR INTERNACIONAL
}

Dr. Raúl Fornet-Betancourt, Missionswissenschaftliches Institut Missio, Aachen, Alemania.

Dr. Luis Rivera-Pagán, Princeton Theological Seminary, Princeton, New Jersey, Estados Unidos.

Dr. Jung Mo Sung, Universidade Metodista, Sao Paulo, Brasil.

Dr. Amando Robles Robles, Centro Dominico de Investigaciones, Costa Rica.

Lic. Helio Gallardo, Universidad de Costa Rica, Costa Rica.

Dra. Maricel Mena, Universidad Santo Tomás, Bogotá, Colombia.

Dr. Juan José Tamayo, Universidad Carlos III, Madrid, España.

M.Sc. Silvia Regina Da Lima, Departamento Ecuménico de Investigaciones, Costa Rica.

Dr. Héctor Samour, UCA, El Salvador.

Dra. Cristina Conti, Ejército de Salvación, Buenos Aires, Argentina.

Dr. Xabier Pikaza, consultor-investigador en Ciencias de la Religión, Salamanca, España.

Dr. Neusa Vaz e Silva, Associação Sul Americana de Filosofia e Teologia Interculturais, Brasil M.Sc. Lilian Conceição da Silva Pessoa de Lira, Escuela Superior de Teología, São Leopoldo, Rio Grande do Sul, Brasil

CORRECCIÓN FILOLÓGICA: M.L. José Marco Segura Jaubert


\author{
Auspiciada por \\ Editorial SEBILA \\ Universidad Bíblica Latinoamericana \\ Convenio UNA-UBL \\ Maestría en Estudios Teológicos
}

Dirección: Escuela Ecuménica de Ciencias de la Religión

Universidad Nacional

Apartado 86-3000. Heredia, Costa Rica

Teléfonos: 2562-4061 / 2562-4063 (fax)

Correo electrónico: revistasiwo@una.cr

Diseño de portada: Érick Quirós Gutiérrez

Diagramación e impresión: Programa de Publicaciones e Impresiones de la Universidad Nacional

Todos los derechos reservados. Esta publicación no puede ser reproducida en forma parcial ni total. La reproducción electrónica debe contar con la autorización de los comités editoriales. 
Siwô'. Revista de Teología es una publicación semestral de la Escuela Ecuménica de Ciencias de la Religión, Facultad de Filosofía y Letras, Universidad Nacional de Costa Rica.

La Revista Ecuménica, Servicio de Información Teológica apareció por primera vez en el 2004, pero a partir del 2008 se cambió el nombre por Siwố: Revista de Teología.

Esta publicación tiene como objetivo promover el desarrollo de la investigación teológica realizada en la Escuela Ecuménica de Ciencias de la Religión y fuera de esta; los artículos son originales e inéditos y discuten temas de la realidad social que integra las problemáticas costarricenses y latinoamericanas.

Siwô’: Revista de Teología está inscrita en Latindex: http://latindex.org/ (Sistema Regional de Información en Línea para Revistas Científicas de América Latina, El Caribe, España y Portugal) y también ofrece su versión en línea a través de la siguiente dirección: http://www.revistas.una.ac.cr/siwo 

Siwồ 10.2 

UNIVERSIDAD ESTATAL A DISTANCIA

\author{
VICERRECTORÍA ACADÉMICA \\ ESCUELA DE CIENCIAS SOCIALES \\ Y HUMANIDADES
}

PROGRAMA DE TEOLOGÍA

UNIVERSIDAD NACIONAL

LA ESPIRITUALIDAD DE LAS DROGAS ENTEOGÉNICAS DEL MUNDO PRECO. LOMBINO ESTUDIADA POR QUIRCE-BALMA: UN ACERCAMIENTO DESDE LA TEOLOGÍA INTERCULTURAL.

TESIS PARA OPTAR POR EL GRADO DE LICENCIATURA EN TEOLOGÍA

ESTUDIANTE:

ALEJANDRO VARGAS CARRANZA

TUTOR: DIEGO SOTO MORERA SAN JOSÉ, 22 DE FEBRERO DE 2017 



\title{
La espiritualidad de las drogas en- teogénicas del mundo precolom- bino estudiada por Quirce-Balma: un acercamiento desde la Teología Intercultural
}

\begin{abstract}
The spirituality of the entheogenic drugs of the pre-Columbian world has been neglected in Latin American theology, even condemned from the most traditional theological lines. In this sense, the contributions of the pre-Columbian entheogenic spirituality studied by Quirce-Balma for the theological reflection in Latin America from an intercultural perspective are determined, for it is given a dialogical approach between the ethnopsychofarmacology of QuirceBalma, the intercultural theology, the theology of Liberation and traditional theology. It also recognizes the spirituality of the entheogenic drugs of the preColumbian world as cultural memory, which enriches intercultural theology and constitutes a means for the dignification of the world.
\end{abstract}

Keywords: Quirce-Balma, pre-Columbian world, entheogens, ethnopsypharmacology, altered states of consciousness, ontopraxis, theological milieu, Teilhard de Chardin, intercultural theology, dialogue and pluralism, cultural memories and dignification of the world.

\section{Resumen}

La espiritualidad de las drogas enteogénicas del mundo precolombino ha sido un aspecto descuidado en la teológica latinoamericana, incluso ha sido condenada desde las líneas teológicas más tradicionales. En este sentido, se determinan los aportes de la espiritualidad enteogénica precolombina estudiada por Quirce-Balma, para la reflexión teológica en América Latina desde una 
perspectiva intercultural, para ello se da un acercamiento dialógico entre la etnopsicofarmacología de Quirce-Balma, la teología intercultural, la teología de la liberación y la teología tradicional. Así mismo se reconoce la espiritualidad de las drogas enteogénicas del mundo precolombino como memoria cultural, que enriquece la teología intercultural y constituye un medio para la dignificación del mundo.

Palabras claves: Quirce-Balma, mundo precolombino, enteógenos, etnopsicofarmacología, Estados Alterados de conciencia, ontopraxis, milieu teológico, Teilhard de Chardin, teología intercultural, diálogo y pluralismo, memorias culturales y dignificación del mundo. 


\section{ÍNDICE}

INDEX

\section{ÍNDICE}

13 Capítulo I. Introducción

i. Planteamiento del problema

ii. Justificación del problema

iii. Antecendentes

I. Directos

II. Indirectos

b) Antecendentes internacionales

iv. Objetivos

Objetivo General

Objetivos Específicos

v. Hipótesis

41 Capítulo II. Marco Teórico

I. Quirce-Balma

II. Estados Alterados de Conciencia

a. Definición

b. Clasificación de los Estados Alterados de Conciencia

c. Estados Alterados de Conciencia con valor espiritual

III. Etnopsicofarmacología

IV. Drogas Enteogénicas

V. Ontopraxis

VI. El Milieu teológico

VII. Teología intercultural

VIII. Teología tradicional y teología de la liberación 
67 Capítulo III: Metodología

1. Fuentes

2. Recopilación y sistematización de la información documental

3. Procedimientos de análisis de la información

73 Primer Capítulo

La etnopsicofarcología desde la reflexión teológica

A. Un diálogo desde la teología intercultural

B. El uso farmacológico desde la teología tradicional y la teología de la liberación

C. La etnopisicofarmacología de Quirce-Balma

D. Espiritualidad de las drogas enteogénicas del mundo precolombino

E. La espiritualidad enteogénica desde la teología intercultural

91 Segundo Capítulo

La memoria cultural de la espiritualidad enteogénica y la ontopraxis

1. La historia del cristianismo contra la historia de las espiritualidades enteogénicas precolombinas

2. La ontopraxis y las espiritualidades enteogénicas precolombinas

101 Tercer Capítulo

El Milieu teológico. Una dignificación del mundo

105 Capítulo IV. Conclusiones

109 Referencias bibliográficas

115 Anexo 


\section{Capítulo I}

\section{INTRODUCCIÓN}

\section{i. Planteamiento del problema.}

La espiritualidad de las drogas enteogénicas del mundo precolombino ha sido un aspecto descuidado en la teológica latinoamericana, incluso ha sido condenada desde las líneas teológicas más tradicionales. En este marco se realiza un acercamiento a los estudios etnopsicofarmacológicos de Quirce-Balma sobre esta espiritualidad, que permitiría ampliar los horizontes de reflexión teológica en América Latina desde una perspectiva intercultural.

\section{ii. Justificación del problema.}

Tanto artística como académicamente el acto poético se conduce por el deseo. Es imposible en ausencia de una motivación conducirse a una meta, sea esta lúdica, cotidiana o trascendente. Ese deseo puede advenir desde la inspiración religiosa, la necesidad orgánica, la curiosidad científica o el impulso artístico. Por 


\section{SIWÔ ? volumen 10, Número 2, 2016}

esto es ineludible hacer referencia a las motivaciones que llevan al esfuerzo académico cuando se elige un tema de investigación.

En América Latina los ordenamientos jurídicos y la religión institucionalizada, principalmente la católica, han censurado, condenado y hasta perseguido la espiritualidad "farmacológica", desde el tiempo de la conquista española. Si bien los conquistadores españoles admiraron en principio las riquezas botánicas y médicas de América, la admiración y el deseo topó con el perjuicio racial y otros clichés etnocéntricos; toda vez que las drogas medicinales, también, eran psicoactivas y, generalmente, se empleaban en contextos religiosos o análogos. Esto derivó en una pesquisa inquisitorial exhaustiva contra los amerindios (Escohotado, 2002).

Esta censura y persecución se tradujo en olvido o descuido del valor espiritual psicofarmacológico por parte de la producción teológica latinoamericana desde sus líneas más tradicionales. Incluso, salvo escasas valoraciones teológicas, como las de Boff (2016) respecto a la eucaristía y la ayahuasca en la Doctrina de Santo Daime, llama la atención que la Teología Latinoamericana de la Liberación, que aspira a una crítica y superación de las teologías tradicionales, no haya discurrido suficientemente sobre este núcleo que atañe, entre otros procederes místicos y religiosos, a prácticas espirituales precolombinas, avasalladas por la conquista y colonización, siendo que algunas de estas aún perviven en pueblos indígenas de América.

Ciertamente la Teología Latinoamericana de la Liberación consiste en un proceso que engloba experiencias disímiles: producción teológica, prácticas pastorales, movimientos extraeclesiales, movimientos intraeclesiales (v.gr. de la Iglesia católica), movilizaciones políticas (incluidas organizaciones político-militares), Comunidades Eclesiales de Base y otros movimientos 
liberadores (Gallardo, 2009). Tampoco resulta ser un paradigma sin conflictos y diferencias en sus planteamientos, por ejemplo, salta a la vista una considerable diferencia metodológica entre una misa guerrilla con Ernesto Cardenal y la propuesta económica de Franz Hinkelammert.

En este sentido, la propuesta de Quirce-Balma puede implicar una divergencia de la metodología tradicional en teología y un aporte a la Teología Latinoamericana de la Liberación, pues se permitiría ampliar los horizontes de reflexión teológica en América Latina desde una perspectiva intercultural. Esto último en el marco de los retos que la filosofía intercultural plantea a la teología, específicamente a las teologías latinoamericanas de la liberación, a manera de representar un desafío y una tarea por cumplir, con el fin de no ignorar la validez de otras perspectivas teológicas (Madrigal, 2008).

Una perspectiva teológica puede darse en valoración de la propuesta de Quirce-Balma, quien sobre el trasfondo etnopsicorfarmacológico elabora, con estudios de la dinámica neurocerebral, una sustentación de la ontopraxis, consistente en "una vivencia total del individuo en favor de una evolución global de su cultura", en donde se suscita "una dialéctica en la vida humana entre lo familiar y lo no-familiar, con finalidad de transformación de orden ontológica, compréndase a su vez como una dialéctica de cambio individual como expresión de la dialéctica histórica de evolución social" (Quirce-Balma, 1976, pp. 23-24). Por lo tanto, es en su finalidad una propuesta al cambio social a partir del sujeto.

La relación Biología-Psicología-Sociedad fue constante en los trabajos de Quirce-Balma, promotor del desarrollo de las neurociencias en el país, miembro distinguido y fundador del Colegio de Psicólogos de Costa Rica, y ante todo químico 


\section{SIWÔ ? volumen 10, Número 2, 2016}

destacado. Es a través de sus estudios en etnopsicofarmacología que obtenemos las aproximaciones hacia esa relación desde un campo interdisciplinario.

La etnopsicofarmacología tiene, desde ese lugar, el privilegio de aportar a la discusión teológica una nueva perspectiva que va más allá del marco religioso para remitir a lo espiritual. Esto último implica un reto a la reflexión teológica, puesto que más que un fenómeno religioso, la teología trata de ver cómo la religión expresa u opaca la espiritualidad (Avendaño-Herrera, 2005).

Así mismo la etnopsicofarmacología adquiere un matiz pneumocientífico, pues vincula la espiritualidad con el rigor científico para convertirse de algún modo en una ciencia de la religión. En este caso, para los intereses que atañen a esta investigación, la etnopsicofarmacología aborda la espiritualidad originada por enteógenos, estudiando los Estados Alterados de Conciencia derivados del consumo de estas sustancias psicoactivas.

Quirce-Balma se dio la difícil tarea de establecer conexiones entre la psicofarmacología, la antropología y la religión, entre otros temas (Quirce-Balma, 2009). La vinculación de estos temas a través del estudio de culturas actuales y precolombinas en su relación con plantas psicodélicas, sugiere una concepción de que el sujeto debe alcanzar la experiencia mística para poder vincularse con los demás seres planetarios y lograr así plenitud y felicidad. Esta visión de las experiencias chamánicas como parte fundamental de la sociedad primitiva, íntimamente ligada a la herbología enteogénica, y ante todo como una experiencia con la realidad, pero con un vínculo más fuerte con la naturaleza, son parte de su pensamiento (Quirce-Balma, 2010a). La promoción de la reflexión teológica e investigación en esta área para lograr una visión más sistémica y menos limitada por la 
construcción lógico-material del pensamiento occidental, resulta de máxima prioridad.

$Y$ es que cabe destacar que Latinoamérica sufre como señalaba Quirce-Balma una "brecha en la investigación científica existente entre América Latina y el resto del mundo" (QuirceBalma, 2009, p. 86) que no es justificable siendo América Latina, como describiría Hofman respecto a México en específico, "un santuario de las drogas alucinógenas" (Guerin \& de Sedouy; \& Roumette, 1993).

Quirce-Balma (2009) señaló la necesidad de aprovechar la amplia variedad de fuentes culturales, botánicas y herencias espirituales que en hay en Latinoamérica. Sin embargo, el fuerte de la investigación en etnopsicofarmacología no proviene de investigadores de la región sino de personas del exterior que trabajan en la zona.

Acusa Quirce-Balma (2010) al referirse al estado de la investigación sobre estos temas que en Costa Rica: "no se ha hecho aún nada por identificar la botánica enteogénica del país” (p. 13).

Se han reanudado de este modo desde los años 60 y la llamada "era californiana" de los psicodélicos, los círculos de dependencia exterior que caracterizan otros procesos macro en Latinoamérica, como la economía, la política y la producción. Quirce-Balma (2010a) señala la riqueza relativa de esta región cuando destaca, por ejemplo:

Los indígenas del norte del continente americano no tenían, quizás por el clima, la variedad de opciones enteogénicas de sus hermanos mexicanos o centroamericanos o suramericanos. (p. 5)

Perspectiva que debería justificar con mayor medida la necesidad de aprovechar esa posición de privilegio y promover la 


\section{SIXÓ ? Volumen 10, Número 2, 2016}

evolución de Latinoamérica como potencia en este campo de estudio etnopsicofarmacológico. Siendo además destacada la región por una vasta herencia espiritual, que ha estado en muchos casos ligada a las plantas enteógenas. La relevancia de la relación entre religión y botánica se encuentra desde Pokorny (1970), citado por Quirce-Balma y Maickel (2009), donde se resalta un antiguo vínculo entre el quehacer religioso y el chamánico, que data desde épocas paleolíticas.

La etnopsicofarmacología en Quirce-Balma, con su orientación hacia la experiencia individual desde la ontopraxis y su proposición de un Milieu teológico, que conduzca a una sociedad latinoamericana más próspera, pretenden ser los primeros pasos de una teología latinoamericana liberadora que considere la espiritualidad originada por psicofármacos.

En este sentido, se propone una reflexión teológica que se distancia de líneas tradicionales teológicas y de las ciencias de la religión. Se trata así de una investigación documental entendida como aquella que destaca la búsqueda de documentos y bibliografías, su caracterización, cuestionamiento, crítica, verificación e identificación en pro de la determinación de su pertinencia, veracidad, función, y rango de alcance (Gallardo, 2013).

Meta coherente con el Milieu teológico propuesto por Quirce-Balma:

El punto fundamental de todo esto es que una época materialista está siempre orientada a afectar el cuestionamiento de la validez de la vida y una época teológica no lo está. El nihilismo fraguado en la época empresarial intenta reducir los tiempos y espacios teológicos del ser humano, al establecer lo mudo en sustitución a la conversación viva del hombre para con Dios. El milieu materialista de una forma o de la otra llevará siempre a las personas a una soledad tremenda." "El milieu teológico permite conversar sobre 
nuestra existencia y su propósito y no meramente aceptar lo existente como lo irreversible sin cuestionamiento o trascendencia." Si el milieu materialista nos aísla con soledad, el milieu teológico nos une en esperanza. El milieu teológico como época que glorifica al hombre y a su relación con Dios, crea personas más sanas y equilibradas que las épocas materialistas. (Quirce-Balma, 2 de agosto de 2011)

\section{iii. Antecedentes}

En el caso de la presente investigación es sencillo hacer un seguimiento que lleve al antecedente de su concepción. Consiste en el trabajo que se coordinara con el Doctor Quirce-Balma en años anteriores, culminando en la publicación de un artículo en el año 2012. Artículo donde se comparan los aportes de Teilhard de Chardin y Quirce-Balma. Se Resaltan sus propuestas teóricas para solucionar los problemas de la cultura actual (Vargas-Carranza, 2013).

Seguidamente, se abordan los estudios nacionales e internacionales sobre el tema en estudio. Las investigaciones presentadas aquí se refieren en su mayoría a aspectos en relación con la teología, los Estados Alterados de Conciencia (EAC) y la espiritualidad; así como la etnopsicofarmacología, la psicología y la religión. Se pretende responder a las preguntas: ¿qué se ha hecho en teología y qué se ha hecho en otras disciplinas?, y ¿qué se ha hecho en teología y qué no se ha hecho?

\section{Directos.}

De forma directa, cabe destacar una entrevista Sobre el pensamiento de Teilhard de Chardin, que realizó el proponente a Quirce-Balma el 11 de setiembre de 2011 en el Laboratorio de Estrés y Neuropsicofarmacología de la Facultad de Farmacia de la Universidad de Costa Rica, en la que destaca el papel de los estados propiciados por la meditación y la farmacología para 


\section{SIXÔ ’ volumen 10, Número 2, 2016}

establecer una conexión con lo trascendente, ello desde un diálogo entre la ciencia y la religión. En esta línea se encuentra el indicado artículo, también del proponente, con el título Los aportes de la pneumociencia de Teilhard de Chardin y de QuirceBalma para el actual problema de desespiritualización vivido en Occidente (2012), publicado en la Revista Siwô de la Escuela de Teología de la Universidad Nacional, en el que se sostiene, desde la continuidad del pensamiento teilhardiano en la obra de Quirce-Balma, la necesidad histórica de llegar a un Milieu teológico caracterizado por los EAC.

También destaca un artículo del investigador José Manuel Rodríguez Arce, asistente de Quirce-Balma, que inicia un estudio que culmina en la publicación de Las plantas y los hongos alucinógenos: Reflexiones preliminares sobre su rol en la evolución humana (2012), artículo publicado luego del fallecimiento de Quirce-Balma en la Revista Reflexiones de la Facultad de Ciencias Sociales de la Universidad de Costa Rica.

\section{Indirectos.}

De forma indirecta se ha aludido al objeto de estudio de Quirce-Balma por parte de Armando Robles Robles (2010) en su libro Hombre y mujer de conocimiento. La propuesta de Juan Matus y Carlos Castañeda, que presenta una espiritualidad laica que privilegia el espíritu vivido de forma experiencial. Ello de conformidad con los escritos de Carlos Castañeda, a través de los cuales el estudio se acerca al chamanismo de Juan Matus, en el que están presentes el consumo de fármacos botánicos y experiencias místicas. En la propuesta que hace Carlos Castaneda se descubre que todo el legado cultural que siempre se buscó en Oriente, también se encuentra en Occidente.

El autor empieza por indicar que la propuesta de Castaneda es totalmente laica, y la define como la espiritualidad que 
se puede hacer hoy; una espiritualidad laica, pero no religiosa; y aunque la propuesta de Robles (2010) es amplia y profunda, es en su capítulo dos, acerca de la espiritualidad, donde se encuentra una relación de importancia con el tema tratado en la presente investigación.

La espiritualidad, según Robles (2010), retomando la propuesta desde Castaneda, implica la capacidad del humano de ser desinteresado y una desengocentración total del ser, esta espiritualidad no se confunde nunca con espiritualidades similares, “...es un fin en sí misma, nunca un medio..." (p. 43).

Para Robles (2010) dos características importantes de este tipo de espiritualidad son lo inexpresable y lo laica. Además, justifica el interés en la propuesta de Castaneda por ser una propuesta acorde con las necesidades del ser humano de hoy, una propuesta de conocimiento.

Si bien es cierto que se aborda el mismo objeto de QuirceBalma, resulta en una aproximación que pondera una experiencia subjetiva enteogénica, distinta a la de Quirce-Balma que recurre a una instrumentalización de las ciencias exactas para estudiar y explicar la experiencia enteogénica en el cerebro.

También existe un acercamiento al fenómeno religioso desde una perspectiva psicológica por parte de Tapia (1993), en su tesis de grado Psicología de la religión: aproximación teórica-reconstructiva a un modelo de investigación desde Costa Rica, trabajo en el que el objeto es lo psicoreligioso desde las dimensiones numinosatrascendente y sociopersonal. Particularmente la dimensión numinosa-trascendente no es concebida como un discurso sobre Dios (papel de la teología) o un discurso sobre la fundamentación última de la posibilidad de Dios (papel de la filosofía), sino como la vivencia psíquica de los sujetos en relación a Dios, a lo numinoso-trascendente, lo numinoso entendido como lo santo y 


\section{SIWÔ ${ }_{\text {Volumen 10, Número 2, } 2016}$}

lo sagrado, que supone una estructura fenómenica conformadora del psiquismo del sujeto. Si bien este último particular mantiene relación con el objeto de estudio de Quirce-Balma, lo cierto es que el análisis no entra en las particularidades biológicas del fenómeno desde la que Quirce-Balma extrae sus resultados.

En el campo de las ciencias cognitivas, en Costa Rica destaca el trabajo de Arce Arenales (2010), que en el artículo Algunos principios de la Teoría de Dinámica de Tropas, alude desde esta teoría gestada por él a la religión y al idioma como características subsecuentes de una Hiper Tropa, en donde grandes poblaciones tuvieron que recurrir a formas simbólicas cargadas afectivamente (emocionalmente) para sustituir la vida en tropa. También, este mismo autor abordara el fenómeno de la religión en La Esfinge y el espejo, Occidente y sus orígenes (2010), como una visión interpretativa desde Centroamérica sobre la cultura euroasiática occidental traslapada a América, especialmente en la península ibérica y la británica.

La etnopsicofarmacología de Quirce-Balma comparte con Arce-Arenales (2008) el hecho de ser un pensamiento situado, en el contexto en que se desarrolla, aunque el abordaje de Quirce-Balma es diferente en cuanto a la interpretación del fenómeno espiritual, que responde a la ontopraxis; mientras que Arce-Arenales, lo vincula a la Teoría Dinámica de Tropas o lo considera repensando la historia.

Expuestos los antecedentes nacionales directos e indirectos, que recopilan la poca, pero importante información sobre el presente trabajo de investigación, se presentan a continuación los antecedentes internacionales. 


\section{b. Antecedentes internacionales}

A nivel internacional, la teología tradicional no ahonda en el carácter espiritual de las sustancias psicoactivas, a principios del s. XXI la posición teológica respecto a las drogas es mayoritariamente negativa, asociada a la adicción y al narcotráfico, tal es el caso del Manual católico Iglesia, Droga y Toxicomanía del Pontificio Consejo para la Pastoral de la Salud (2001), que salvo escasas valoraciones teológicas, como la de Boff (2016), respecto a la eucaristía y la ayahuasca en la Doctrina de Santo Daime, indica lo siguiente:

Santo Daime es un camino espiritual nacido en Brasil a partir de los pueblos de la foresta amazónica. Es una creación en la cual confluyen muchos aportes, sea del cristianismo oficial, del cristianismo popular, de las creencias indígenas y de los pueblos mestizos de la región amazónica. En sus celebraciones toman Santo Daime. Lo toman ritualmente como nosotros cristianos tomamos el vino-sangre y el pan-cuerpo del Señor. No se trata de forma alguna de una droga, sino de una bevanda ritual. Y así debe de ser entendida. (s.p.)

Sin embargo, más allá de la teología, se encuentran numerosos estudios que guardan relación con la presente investigación, entre ellos:

Winkelman (2004) propone que la neuroteología proporciona un importante enlace entre las perspectivas religiosas y científicas. Sin embargo, destaca que en esta práctica no se han valorado lo suficiente las implicaciones de una forma de sanación primordial, como lo es la espiritual-chamánica.

Señala que el papel de las funciones cerebrales en las experiencias espirituales se ha puesto, cada vez más, en evidencia en diferentes estudios alrededor del mundo. Los principios universales del chamanismo han puesto en la mira una serie de 


\section{SIWÔ ${ }_{\text {Volumen 10, Número 2, } 2016}$}

procesos neurológicos subyacentes y proporcionan una base para una teología evolutiva; además revelan que enfoques del chamanismo como el animismo, el totemismo, el vuelo del alma, los espíritus animales, y la muerte-y-renacimiento, son todas experiencias que contienen operaciones cerebrales fundamentales (Winkelman, 2004).

Las terapias chamánicas implican mecanismos biológicos para la transformación de la salud de la persona, mejorando el placebo y otros efectos psicosomáticos; el chamanismo coloca las circunstancias del paciente dentro del más amplio contexto de la mitología cultural y manipula ritualmente las relaciones, que transforman emocionalmente al paciente; estos rituales en los que se manipulan las estructuras psicológicas y fisiológicas inconscientes, permiten a los curanderos chamánicos evocar respuestas cognitivas y emocionales que pueden llevar a cambios fisiológicos en la persona (Winkelman, 2004).

El autor describe el paradigma chamánico de la neuroteología y el chamanismo en las bases de la evolución cognitiva humana y la experiencia espiritual. Las practicas chamánicas intensifican las conexiones entre el sistema límbico y las estructuras cerebrales más bajas. Estas dinámicas mejoran la atención, la conciencia de sí mismo, el aprendizaje, la memoria y los mecanismos internos de cada quien (Winkelman, 2004).

Quirce-Balma (2010) comparte con Winkelman (2004) las premisas sobre el chamanismo y el recurrir al estudio de la espiritualidad con rigor científico, lo que para Winkelman vendría a ser la neuroteología. Esta posición de diálogo interdisciplinario es sobre la que versa el trabajo de Quirce-Balma, objeto de esta investigación.

Los alcances de Winkelman (2004) en cuanto a la espiritualidad chamánica y el valor medicinal son puntos que destaca Quirce-Balma (2011), dicho autor mira en la facilidad de 
sincronización ínter hemisférica y el desarrollo de rituales exitosos, así como en el encuentro con plantas que producen estados superiores de conciencia que denominaríamos enteogénicos y estados alterados de conciencia que se necesitan enteogenizar, como las causas fundamentales de las capacidades chamánicas.

Por otra parte, Newberg \& Newberg (2005) estudian la neuropsicología de la religiosidad y las experiencias espirituales, e indican que la religiosidad, la espiritualidad, la oración y los rituales dentro de la meditación, han sido ampliamente descritos desde los campos de la biomedicina, psicología, antropología y literatura religiosa, desde hace muchos miles de años.

Sostienen que recientemente han aumentado los estudios de la neuropsicología y psicología que investigan la correlación entre las experiencias de religiosidad y espiritualidad, con experiencias como las mencionadas anteriormente. En este sentido han sido un campo temático de la neurobiología y la neuropsicología (Newberg \& Newberg, 2005).

Los autores exponen que existe una relación entre lo cognitivo, el sistema nervioso autónomo y el endocrino. En esta relación se dan estados inspiradores e intensamente místicos, donde el rango de las experiencias religiosas y espirituales va desde algo que simplemente inspira a una persona, hasta el extremo de creer en algo místico (Newberg \& Newberg, 2005).

Respecto al desarrollo del cerebro y la experiencia espiritual, señalan que esta última ha repercutido en la evolución, pues ha permitido una red de conexiones importantes en el cerebro, donde las estructuras más evolucionadas se han conectado a las estructuras más primitivas como el sistema límbico (Newberg \& Newberg, 2005). 
Sobre esta línea, el cerebro puede ser dividido funcionalmente en funciones cognitivas del cerebro, con "operadores cognitivos" y experiencias terrenales, que se estudian por medio de los "operadores causales". El operador causal provee una secuencia de eventos de la realidad, en cuanto a tiempo o espacio, abstrayendo las percepciones de los sentidos, ordenando los eventos en "bandas", pero si el evento que se encuentra tratando de organizar no tiene una causa lógica, el operador causal automáticamente va a generar un inicio o una causa asociado a dioses, poderes o espíritus (Newberg \& Newberg, 2005).

Además, se da que el operador holístico, que se encuentra en el lado derecho del cerebro (lóbulo parietal), permite que la realidad sea vista como un todo o "gestalt", sus funciones generan el entendimiento del todo, la percepción sensorial y la abstracción de conceptos (Newberg \& Newberg, 2005).

Quirce-Balma (2010) con respecto a Newberg \& Newberg (2005) mantiene una cercanía de forma similar a Winkelman (2004), en tanto a la interdisciplinariedad entre ciencias como neurobiología y neuropsicología en el estudio del fenómeno religioso, aunque en las categorías de análisis de Quirce-Balma (2009) no aparecen los conceptos de operadores causales y cognitivos, pues Quirce-Balma como se ha indicado, utiliza el concepto de EAC.

En cuanto a las fuentes de los estados superiores de conciencia, se encuentra el estudio de Taylor (2005), quien toma como punto de partida la cuestión del cómo y el porqué de los estados superiores de conciencia, que nunca han tenido una respuesta clara; dándose intentos de explicación desde la neurología y la neuropsicología. Taylor remite a Fischer (1971), quien proponía que existían estados "ergotrópicos" o estados superiores de conciencia o "alta activación" y "trofotrópico" o estados de 
"experiencias pasivas y serenas de activación". Los estados de alta excitación se encuentran relacionadas con factores desencadenantes tales como las drogas, el baile, el ayuno y el control de la respiración, mientras que los estados de baja excitación se relacionan con factores desencadenantes como la meditación y la relajación.

Ahora bien, Taylor (2005) viene a sugerir que estos dos tipos de experiencia mística (de alta activación y de baja activación) se desprenden de dos fuentes distintas. Eruditos, místicos y guías espirituales en general, están de acuerdo en que la experiencia mística/espiritual tiene una serie de características fundamentales, como una percepción intensificada del mundo fenomenológico, una sensación de paz y plenitud interior, una sensación de unidad con el mundo manifiesto (o un sentido de trascender límites) y un sentido de lograr un sí mismo más profundo y más verdadero. Sin embargo, no todas estas características son comunes en ambos tipos de altos estados alterados de concienca.

Argumenta que las denominadas "experiencias místicas" pueden tener su causa en dos aspectos: una alteración de la homeostasis normal del organismo humano (HD) o una intensificación de la "conciencia-energía" (ICE) que constituye el ser (Taylor, 2005).

La homeostasis vendría a ser la condición óptima de funcionamiento biológico del cuerpo, que incluye factores como temperatura corporal, sangre, azúcar, concentración de sal, entre otros. El mantenimiento de todas estas condiciones es a la vez voluntaria e involuntaria; y cuando no se logra este equilibrio, se está expuesto a enfermedad o muerte; aunque la interrupción de la homeóstasis puede también, ser utilizada como una "tecnología de la experiencia espiritual"; ya que menores niveles de glucosa en sangre, altos niveles de insulina y un cuerpo con 
temperatura inferior, parecen abrir la puerta de estados superiores a la conciencia ordinaria (Taylor, 2005).

La “conciencia-energía” o "energía psíquica” constituiría el principio activo de la conciencia, la energía que se usa para ser consciente en el acto de percibir el mundo fenomenal, es parte de la experiencia y del pensar lógica y discursivamente. Taylor (2005) afirma que casi cualquier actividad que implique cierto grado de concentración y tranquilidad, puede resultar en una intensificación y movilización de esta energía vital y podría dar lugar a una experiencia espiritual.

A esta razón se investigan ambos tipos de experiencia y se comparan y contrastan entre ellos, concluyendo que la intensificación de la "conciencia-energía” es el único estado realmente positivo y que puede ser convertido en un integrado y permanente estado de conciencia superior (Taylor, 2005).

Si bien Taylor (2005) guarda un acercamiento con QuirceBalma (1976) en el abordaje del fenómeno místico, no entra en el nivel de clasificación de los EAC, ni mucho menos alcanza el detalle en el abordaje de la experiencia religiosa psicoactiva a la luz del estudio de dichos EAC (Quirce-Balma, 2009).

Por otra parte, Hood (2005) realiza un estudio sobre espiritualidad, misticismo y experiencias religiosas, analiza el debate entre religión y espiritualidad desde la psicología de la religión. Considera necesario identificar cuándo cada uno de estos conceptos van diferenciados; indica que estas dos significaciones comparten tres aspectos: "sentido de", "creencia en" y "búsqueda de lo transcendente".

Lo anterior porque, aunque la mayor parte de las personas religiosas se definen como espirituales, en la actualidad se encuentra un grupo emergente que se define como espiritual, pero 
no religioso, lo que lleva a que el concepto de espiritualidad siga aún difuso. Por esta razón, indica que estudios previos han identificado que las experiencias religiosas tienen una utilidad en la restricción normativa y en el apoyo social (Hood, 2005).

Hood (2005) realiza un apartado especial sobre psicotrópicos y enteógenos, indica que es un área controversial, ya que algunos argumentan que las drogas pueden facilitar las experiencias religiosas y espirituales y que las sustancias naturales son utilizadas por diferentes religiones para llegar a estados alterados de conciencia. Nace entonces la arquiopsicofarmacología que estudia tantos textos antiguos y arcaicos utensilios como grupos contemporáneos, que usan naturalmente sustancias psicodélicas, dando así una especulación sobre el origen de la religión.

Râtach (1990), citado por Hood (2005), indica que desde los años '70 existe poca investigación en el campo de las sustancias psicodélicas, pero en la actualidad se encuentran en desarrollo estudios de importancia por parte de antropólogos y etnobotánicos, con sustancias naturales y enteógenos, en países europeos donde hay mayor flexibilidad en la legislación.

Para finalizar, el autor hace mención a que dentro del llamado movimiento psicodélico se ha fallado en la aceptación de las drogas dentro del marco religioso para uso sacramental, pero se pueden encontrar dos excepciones, la iglesia nativa americana en Estados Unidos y la iglesia de Santo Daime en Brazil (Hood, 2005).

Por otra parte, realiza un análisis y presentación de las principales tesis comunes en el estudio de la mística, menciona que existen dos polos que han definido la psicología de la religión desde sus inicios. En un polo se encuentran los psicólogos como Freud, convencidos de la falsedad de las creencias religiosas, que dan una interpretación reduccionista-naturalista de los fenómenos religiosos; en el otro polo están aquellos psicólogos 


\section{SIXÔ ’ volumen 10, Número 2, 2016}

comprometidos con una cosmovisión religiosa, quienes buscan defender los reclamos ontológicos de la religión (Hood, 2006).

Hood (2006) identifica seis supuestos focos del debate filosófico acerca del núcleo común del misticismo, el primero refiere a la experiencia religiosa como personal, que tiene "su raíz y centro en los estados místicos" (James, 1902, p. 301, citado en Hood, 2006). El segundo se desglosa del anterior y se refiere a las ortodoxias, que se desprenden de una interpretación de una experiencia más que en la propia experiencia. El tercer supuesto versa sobre lo inefable de las experiencias místicas, aunque irónicamente los místicos escriben grandes tesis acerca del tema, por lo que estos escritos no deberían tomarse como descripciones literarias de la experiencia. El cuarto supuesto propone que las experiencias místicas no son simplemente estados emotivos, ni recuerdos cognitivos de verdades que se encuentran a disposición del intelecto. Mientras el quinto supuesto plantea que, para la exploración adecuada de la experiencia mística, se deben incluir métodos fenomenológicos. El sexto y último supuesto se denomina "indiferencia causal", y lo que trata es de incluir todas las experiencias místicas independientemente del contexto o condiciones en las que se da. La polémica surge en el hecho de que los llamados psicodélicos pueden llevar a experiencias místicas (Hood, 2006).

Hood (2006) concluye que este análisis permite un acercamiento a una tesis básica común, donde las religiones son mucho más que esfuerzos por hacer frente a la experiencia mística. Las experiencias místicas comparten un núcleo común, estas pueden provocar un sentido de miedo que lleve de cierta forma a una explicación religiosa; es allí donde los místicos presentan indiferencia u hostilidad hacia las religiones, y se identifican únicamente con la espiritualidad (Hood, 2006). 
El punto de encuentro en Quirce-Balma (2009) y Hood (2006) se inscribe en el análisis del fenómeno enteogénico, fuera de ello las categorías de análisis son bastantes distintas, pues como se ha indicado, los EAC constituyen un tema central del estudio etnopsicofarmacológico (Quirce-Balma, 1976; QuirceBalma, 2009).

Otro de los estudiosos que se refiere al uso de sustancias con carácter sagrado es Ochoa (2010), quien destaca el uso de sustancias con capacidad de curar y dañar, siendo, las mismas, parte fundamental de las prendas-ngangas-enquisos, medio fundamental en ritos del Palo, que es una espiritualidad ligada a la muerte y a la comunicación con los muertos en Cuba. Sin embargo, no existe mayor detalle respecto a la composición química de tales sustancias, pues el estudio se centra en la experiencia de los rituales, de este modo se da una diferencia considerable con QuirceBalma, quien se centra más en dicha composición y sus efectos.

Por otra parte, en 2006, Nichols \& Chemel estudian la neurofarmacología de la experiencia religiosa, realizan un análisis de los alucinógenos y la experiencia divina, e inician una exposición acerca de la ciencia y la religión, indican que estas dos tienen su punto de encuentro en la mente humana, ya que la neurociencia actual considera que todo el espectro de la conciencia humana es el resultado de una complejidad de acontecimientos dentro del sistema nervioso.

En este marco se comienza a definir lo que se entiende por agente psicodélico/alucinógeno, el cual se caracteriza por producir estados de percepción, pensamiento y sensación alterados. Ahora bien, acerca del impacto de los agentes psicodélicos sobre el pensamiento religioso, resaltan que, a lo largo de la historia el ser humano ha ingerido materiales psicoactivos, principalmente en forma 


\section{SIWÔ ? volumen 10, Número 2, 2016}

de plantas y extractos de éstas, por medio de los cuales han tenido estados alterados de conciencia (Nichols \& Chemel, 2006).

En cuanto a la neurofarmacología de los alucinógenos, la investigación destaca que los mismos pueden clasificarse en tres grupos estructurales: triptaminas, fenetilaminas y ergolinas. Sin embargo, los alucinógenos no pueden ser utilizados fácilmente en la investigación y por ellos la base neuroquímica de la conciencia aún no ha sido aclarada (Nichols \& Chemel, 2006).

Nichols \& Chemel (2006) concluyen que el uso de sustancias no debe ser basado en miedos e intimidaciones irracionales; sino más bien, que se debe apreciar su valor por medio de información veraz y libre de distorsiones, aceptando que estas sustancias tienen sus orígenes en la Antigüedad y que tienen mucho por enseñar a la humanidad.

Nichols \& Chemel (2006) mantienen cercanía con QuirceBalma (2009), en tanto el estudio de los alucinógenos a nivel del neurológico es una de los fuertes de la Teoría del Gating de Quirce-Balma. Incluso Nichols es considerado con otra investigación en el estudio de los alucinógenos (Quirce-Balma, 2009). Sin embargo, el concepto de EAC Nichols \& Chemel (2006) no conforma la base de sus categorías de análisis, como en QuirceBalma (1976) y Quirce-Balma (2009).

En 2006, Winkelman resume estudios transculturales sobre el carácter intercultural del chamanismo y la distribución universal de los curanderos chamánicos, en la búsqueda de las raíces biológicas del chamanismo; tomando en cuenta que la definición del término "chamán" ha sido difícil y se ha utilizado para indicar diferentes practicas mágico-religiosas en general.

Menciona así las bases biológicas universales del chamanismo; cuyos aspectos centrales implican raíces biogenéticas y 
funcionales del ritual como parte de una comunicación y un sistema de coordinación social; también indica los estados alterados de conciencia que producen un modo de integración de las potencialidades del cerebro, la manipulación de módulos de representación innatos u operados cognitivos, que se encuentran relacionados con la auto-conciencia y la identidad social, así como formas de pensamiento integradoras basadas en un sistema de representación análoga (Winkelman, 2006).

Ahora bien, se concluye que, si bien no todas las religiones se basan en el chamanismo y los estados alterados de conciencia, la mayor parte de las sociedades han basado las prácticas religiosas en la curación chamánica, y las raíces biológicas del chamanismo muestran el uso de los estados alterados de conciencia para la curación, ello para obtener un contacto con el mundo espiritual (Winkelman, 2006).

Para Quirce-Balma (2010), considerando a Winkelman (2006) y otras investigaciones posteriores de este mismo autor, las personas que desarrollan rasgos chamánicos han tenido largos periodos de una tecnología de la conciencia de tipo meditativo, contemplativo, de oración, ayunos y dietas inteligentemente diseñadas, repetición de mantras, uso de mándalas, lecturas de tipo enaltecedor, reflexiones filosóficas y teológicas, uso inteligente de la herbología y uso igualmente inteligente de sustancias alucinatorias, entre otras. Dichas personas son más sensibles, mas, el uso de dichas metodologías aumenta la sincronización entre el hemisferio izquierdo y el derecho del cerebro. Para Winkelman, dicha sincronización eventualmente llega a establecer nuevos rasgos entre los cuales está la capacidad de curar a otras personas (Quirce-Balma, 2010).

Por otro lado, Rogers \& Paloutzian (2006) presentan un análisis de la neurología de la esquizofrenia y la religión, tratan 


\section{SIWÔ ' volumen 10, Número 2, 2016}

de responder a la pregunta acerca de qué es lo que distingue las experiencias religiosas de quienes tienen esquizofrenia de las experiencias de quienes no la tienen. Indican que las personas con este trastorno tienen la capacidad de experimentar alucinaciones, delirios y experiencias perceptuales diferentes, sería esta la contribución social única de la esquizofrenia.

La tesis de Rogers \& Paloutzian (2006) se podría dividir en tres fases. La primera referida a los aspectos biológicos, neurológicos y sustratos clínicos de la esquizofrenia. La segunda sobre la relación entre la esquizofrenia y la religión, donde analizan el papel de los sistemas frontales y las estructurales temporolímbicas en los delirios religiosos. La tercera es sobre las implicaciones para la biología de los delirios religiosos y la esquizofrenia, desde la evolución y la psicología de la religión.

La esquizofrenia y la religión abren un importante debate en la actualidad, ya que quienes creen en los puntos de vista de Sigmund Freud o Albert Ellis consideran que las creencias religiosas son innecesarias, cuando hay una buena salud mental y perjudicial cuando no la hay. Sin embargo, las personas con esquizofrenia, en muchas ocasiones, ven la religión y la espiritualidad como aspectos de importancia destacada en su afrontamiento y funcionamiento cotidiano, la religión representa para ellos un recurso importante para hacer frente a su condición (Rogers \& Paloutzian, 2006).

Dada esta importancia que se le atribuye por los pacientes a la religión, no es tan sorprendente que mucha de la sintomatología, como alucinaciones y delirios, tengan un contenido o significado religioso; mientras que las investigaciones han revelado que los delirios religiosos en la esquizofrenia tienen sustratos neurales; donde la persona experimenta un aumento en la captación de las regiones temporales frontal e izquierda, así como 
una reducción en la actividad occipital. Se concluye entonces, que la esquizofrenia y la religión se encuentran mediadas por sustratos neurológicos que pueden haber contribuido a una ventaja evolutiva de la esquizofrenia (Rogers \& Paloutzian, 2006).

La distinción entre la esquizofrenia y la religión de Rogers $\&$ Paloutzian (2006), mantiene grandes similitudes con QuirceBalma (1976). De forma similar, los autores comparten la indagación en la dinámica del neurocerebro (Quirce-Balma, 2010).

Por otra parte, Roberts (2006) realiza un estudio acerca de las entradas químicas, y salidas religiosas y enteógenos. Recoge trabajos de farmateología y destaca los importantes efectos que los enteógenos tienen sobre las ideas acerca de la religión, al incluir estudios sobre el cerebro y la religión.

Destaca que los estudios del cerebro religioso son en la mayor parte de las ocasiones descriptivos y caracterizan las actividades que se desarrollan en el sistema nervioso durante las experiencias religiosas; mientras que existen estudios correlacionales que establecen relaciones entre actividades religiosas, variables demográficas, sociales y morales, así como posiciones políticas (Roberts, 2006).

Propone una serie de cuestiones a ser investigadas y hace mención acerca de que en los últimos 40 años se han visto importantes avances en los estudios enteogénicos. La reanudación de estos estudios hará que se exploren campos que antes se encontraban "dormidos" (Roberts, 2006).

Quirce-Balma (2010) guarda con Roberts (2006) una cercanía en la consideración central de la experiencia enteogénica. Sin embargo, este último no presenta la particularidad de Quirce-Balma (1976), de estudiar esta experiencia en vinculación con los EAC, considerados en sus diferencias cualitativas y 


\section{SIXỐ ? Volumen 10, Número 2, 2016}

cuantitativas, aunque sí comparte la alusión a la dinámica cerebral, descrita en la teoría del Gating (Quirce-Balma, 2010).

Mohandas (2008) estudia las bases de la neurobiología de la espiritualidad, desde la propuesta de que las practicas espirituales tienen beneficios sobre la salud mental e indica que la espiritualidad implica la conexión con algo más grande que el ser mismo; además, de que religión y espiritualidad no son términos o acciones que siempre se encuentren juntas.

El autor rescata que, en la mayor parte de los estudios sobre estas temáticas, se ha concluido que la participación religiosa y la espiritualidad se encuentran relacionados con mejores resultados en términos de salud. Por ejemplo, un análisis reciente que resumió los resultados de 147 estudios, con una población total de 98975 sujetos, encontró que la religiosidad se encuentra mayormente asociada con menores niveles de síntomas depresivos (Mohandas, 2008).

Toda esta evidencia apunta a la existencia de una clara asociación, tanto positiva como negativa entre espiritualidad/religión y la salud mental. Sin embargo, existe una escasez respecto a los correlatos neurales de la práctica espiritual, ya que la mayoría de estudios existentes se han concentrado en actividades meditativas (Mohandas, 2008).

Las investigaciones apuntan a que en la meditación espiritual y las prácticas religiosas existe un papel importante de la corteza prefrontal; a la vez cuando ésta se activa, a través de las proyecciones glutamatérgicas, puede activar el tálamo, en especial su núcleo reticular, y con ello activar una especie de red atencional global (Mohandas, 2008).

El autor concluye que los pocos estudios que se han realizado demuestran que existen cambios neuroanatómicos y químicos 
en las prácticas espirituales. Sin embargo, la evidencia se ha obtenido de estudios que examinan principalmente la meditación, los mismos son pequeñas investigaciones, con muestras limitadas, y cuyos resultados no han sido replicados; por lo que existe la necesidad de más investigación de las prácticas espirituales (Mohandas, 2008).

La investigación de Fingelkurts \& Fingelkurts (2009) realiza una revisión sistemática sobre la función del cerebro en la mediación de la experiencia religiosa, revisa argumentos, posiciones y controversias que se han dado en el debate de dicho tema; ven al humano como una entidad psico-somática, con múltiples niveles y dimensiones. En dicho estudio se exponen, además, los niveles de funcionamiento cerebral y el papel de los procesos cognitivos en la experiencia religiosa estudiados desde la neurociencia.

Los autores exponen lo que se entiende por experiencia religiosa, salvaguardan que esta es una de las tres partes de la actividad religiosa (las otras dos son la creencia y la práctica), y que su definición ha sido difícil entre los diferentes estudiosos del tema. Se dice que es una experiencia subjetiva, un fenómeno mundo dentro del cerebro (llamado "mundo-para-mî"); lo que define la experiencia religiosa como el momento de experimentar la realidad divina última, un evento trascendente, que incluye un bienestar y/o unión divina, con una sensación inolvidable, acompañada de emociones y pensamientos religiosos (Fingelkurts \& Fingelkurts, 2009).

Se concluye que un nivel apropiado de análisis del fenómeno de la experiencia religiosa a nivel cerebral, debe tomar en cuenta la experiencia subjetiva, los procesos cognitivos y la actividad cerebral, que a gran escala se relaciona con el nivel fenomenológico de la experiencia subjetiva que tiene el individuo. 


\section{SIWÔ 'volumen 10, Número 2, 2016}

Sin embargo, la teología y la neurociencia son dos formas diferentes de ver y describir el mundo, por lo que el análisis de un fenómeno desde ambos puntos de vista requiere el desarrollo de un marco conceptual común (Fingelkurts \& Fingelkurts, 2009).

La investigación finaliza al indicar que el estudio de la experiencia religiosa tiene una importancia significativa no solo para la teología y la filosofía, sino también para la ciencia y la práctica clínica; por ser el estado en que una persona rompe sus propios límites humanos y podría ser la manera de resolver el problema de la mente subjetiva. Su estudio puede dar luz sobre la mente, la conciencia, el yo y la realidad; así como la relación entre las características fenomenológicas, estados cerebrales, fisiología corporal y comportamiento (Fingelkurts \& Fingelkurts, 2009).

La cercanía con respecto a Mohandas (2006) y Fingelkurts y Fingelkurts (2009), las indica Quirce-Balma (2010), al decir que el primero establece una correlación entre diversas áreas neurocerebrales estimuladas por distintos métodos de oración, meditación y otros métodos utilizados para alcanzar la conciencia más elevada. Mientras que Fingelkurts y Fingelkurts (2009) indican que, toda experiencia religiosa sea alucinatoria o no lo sea, involucra diversas reacciones neurocerebrales y busca distinguir entre el hecho de "manufacturar" a Dios neurológicamente versus la de tener la experiencia directa de "percibir" a Dios.

\section{iv. Objetivos:}

\section{Objetivo general:}

Determinar los aportes de la espiritualidad enteogénica precolombina estudiada por Quirce-Balma para la reflexión teológica en América Latina desde una perspectiva intercultural.

\section{Objetivos específicos:}


Establecer un primer acercamiento dialógico entre la etnofarmacología de Quirce-Balma, la teología intercultural, la teología de la liberación y la teología tradicional.

Distinguir la espiritualidad de las drogas enteogénicas del mundo precolombino como memoria cultural.

Reconocer los aportes teológicos de la espiritualidad de las drogas enteogénicas del mundo precolombino estudiada por Quirce-Balma.

\section{v. Hipótesis.}

"Hipótesis, palabra muy mal escogida para designar el acto espiritual supremo a través del cual el polvo de las experiencias cobra forma y se anima al fuego del conocimiento..." P. Teilhard de Chardin. Epílogo a La activación de la Energía

Se estima como hipótesis de este trabajo el descuido de la espiritualidad de las drogas enteogénicas del mundo precolombino, por parte de la teología latinoamericana, incluso su condena por las líneas teológicas más tradiciones. En este marco, un acercamiento a los estudios etnopsicofarmacológicos de QuirceBalma sobre esta espiritualidad permitiría ampliar los horizontes de reflexión teológica en América Latina desde una perspectiva intercultural. 



\section{Capítulo II}

\section{MARCO TEÓRICO}

\section{Quirce-Balma}

Sobre el Dr. Carlos Manuel Quirce-Balma cabe mencionar su amplísima formación académica, en los campos de química, bioquímica, farmacología, psicología, filosofía y teología, estudios que realizó en el Instituto Químico de Sarriá en Barcelona, España, en la Universidad de Fordham, en Nueva York, en la Universidad de Indiana y en la Universidad de Purdue, Estados Unidos (Guerrero, 2012). En general su formación estuvo influida por la Orden de los Jesuitas, al respeto indicaba:

La educación mía es jesuita, son un montón de años de "jesuitos", desde la Orden. Estudié con la Orden cuatro años del College y tres años graduado: siete años. Y un año antes en España, jocho años con la Orden!, en el Instituto Químico de Sarriá. Yo estoy muy acostumbrado a los jesuitas. (Vargas, 2013) 


\section{SIWÔ ' volumen 10, Número 2, 2016}

En su estancia en el Instituto Químico de Sarriá, aparte de estudiar química y biología, estuvo en contacto con el arte clásico y barroco, así como con las obras de Dalí y presenció la persecución política por el catalanismo. En la Universidad de Fordham estudió ciencia, filosofía, literatura rusa, teología existencial, fenomenología y las obras de Teilhard de Chardin, Rollo May, Martin Heidegger y Erich Fromm. También en Fordham se replantea estudiar química y opta por la psicología clínica, luego de una experiencia "kundalini", adentrándose de este modo en el psicoanálisis, el análisis jungiano y el existencialismo (QuirceBalma, 1988).

Destaca su trabajo con el Dr. Roger P. Maickel, director de la Escuela de Farmacología y Toxicología de la Universidad de Purdue y con el Dr. Varro Tyler, decano de la Facultad de Farmacia de esa misma universidad, con quienes publicó muchos artículos científicos en revistas de prestigio mundial, todas relacionadas con la interacción de diferentes drogas y los efectos del estrés en ratas de laboratorio. Un ejemplo de este trabajo conjunto es el artículo "Concepciones Culturales de los Estados Alterados de Conciencia” (1988). Su tesis doctoral abordó la parte bioquímica del estrés. El Dr. Quirce-Balma fue miembro de la Sociedad Americana de Investigación (Guerrero, 2012).

Paralelamente al estudio de la psicofarmacología con el Dr. Roger P. Maickel mantuvo contacto con el movimiento de la Meditación Transpersonal, llegando a tener cercanía al número uno de los precursores de ese movimiento, el maestro Maharishi Mahesh Yogi (Quirce-Balma, 1988) ${ }^{1}$.

El Dr. Carlos Manuel Quirce-Balma en la Universidad de Costa Rica fue el primer coordinador de la unidad de Psicología entre los años 1974-1976, fue profesor de la Escuela de

1 Documento anexo. 
Psicología y fundador del Colegio de Psicólogos. También fundó y fue el primer director de los Laboratorios de Investigación en Neurociencias, en la Facultad de Farmacia, en 1978 y se mantuvo hasta 1987, cuando se pensionó. Posteriormente se dedicó a hacer varios estudios científicos sobre esquizofrenia (Guerrero, 2012).

En 1977 participó en Panamá en la ALAMOC (Asociación Latinoamericana de Análisis y Modificación de la Conducta). También escribió en revistas ciencias exactas como Neuroeje e Interciencia y de ciencias sociales como Estudios Sociales Centroamericano y Ciencias Sociales (Quirce-Balma, 1988).

Quirce-Balma recibió muchos reconocimientos y premios, incluso fue candidato en 1980 al Premio Príncipe de Asturias, promovido por el Consejo Nacional de Investigaciones Científcas y Tecnológicas (Conicit) (Guerrero, 2012). Desde este mismo Consejo pudo dar a conocer su trabajo en Europa y Estados Unidos (Quirce-Balma, 1988).

Su gran inquietud por investigar y publicar lo llevaron a su regreso a la UCR a desarrollar diferentes proyectos, entre ellos uno sobre los efectos de los hongos alucinógenos taca-taca en ratas, otros sobre el estrés y la nutrición, la nutrición y la conducta locomotora de campo abierto en ratas inyectadas con diversos tipos de anfetaminas (Guerrero, 2012).

Sus investigaciones sobre el estrés fueron las últimas que desarrolló, al respecto mencionaba:

Yo he estado tratando de juntar la neurotomografía, con el grado de los experimentos de Hackman, de Hanson y de otra gente más reciente. Y de un chino muy inteligente llamado Mann, que ha demostrado básicamente que, si usted le produce estrés a un ser humano, el estrés disminuye la capacidad que tienen las áreas superiores frontales el cerebro 
de poder modificar y llevar a cabo un cierto control de las áreas amigdalarias. Por lo tanto, con cierto tipo de drogas, con cierto tipo de forma vida, usted llega a perder el control sobre sus áreas de la amígdala. Por esta falta de control puede producirse esquizofrenia, como dice Grace, incapacidad de controlar funciones violentas o una lentitud en la ejecución neurocerebral, en las regiones ejecutivas del mismo neurocerebro. (Vargas, 2013)

\section{Estados Alterados de Conciencia.}

\section{a. Definición}

Quirce-Balma (1976) caracteriza los Estados Alterados de Conciencia como "toda forma de experiencia de lo percibido que difiera marcadamente de los valores comunes de la sociedad" (p. 15). Sin embargo, para comprender este sentido es menester mencionar las acepciones más generales que han surgido sobre Estados Alterados de Conciencia.

Charles Tart (1969) en la obra Altered States of Consciousness, recopila diversos ensayos sobre el estudio de los Estados Alterados de Conciencia y comienza con rigor positivista a utilizar esta categoría para referirse a un estado distinto de conciencia del que normalmente se tiene, y que está presente en las personas en la mayor parte del tiempo. Éste se produce cuando el sujeto vive un cambio cualitativo en su patrón de funcionamiento mental, donde puede experimentar cambios cuantitativos (variaciones del estado de alerta, en la visualización, entre otras alteraciones semejantes) así como diferencias cualitativas en sus procesos mentales.

En la citada obra la definición de estos estados es ampliada por Ludwig (1969), quien sostiene que un EAC se da por varias maneras o agentes de índole fisiológico, psicológico o farmacológico, que producen un estado reconocido subjetivamente por 
el propio individuo (o por un observador externo) como desviación de la experiencia subjetiva o funcionamiento psicológico del estado de alerta normal del individuo, es decir, de conciencia despierta.

Sin embargo, la definición de EAC es problemática, pues falta acuerdo sobre la denominación más adecuada para referirse al fenómeno al cual hace referencia. Para este último tampoco hay una teoría unificada desde la cual valorarlo y prima un reduccionismo "fenomenológico-psicologista".

Sobre el primer aspecto, indica de la Herrán (2006) que existe una serie de denominaciones asociadas que imposibilitan un acuerdo general, mostrándose así una variedad de perspectivas:

Caycedo (1969) menciona "grados de conciencia". M. Bunge (1980), admite "estado mental". A. Blay (1991) identifica EC [Estado de conciencia] con "niveles de personalidad". R.A. Calle (1978) asocia a "estado mental" una "atención mental" determinada, que los define. J. Krishnamurti, y N. Caballero (1979) hacen referencia a estados de atención con lo superior. S. Krippner et al. (1980) introduce el concepto de "estados de existencia" (p. 20). E. Alfonso (1984) opta por "estados abstractos de la mente" (p. 60). A. de la Herrán (1998) ha utilizado "niveles de amplitud de conciencia", "estados de conciencia extraordinaria", "altos estados de conciencia" (AEC) y "estados de ego". Otros autores utilizan estados especiales, estados alternativos, estados no ordinarios... W. Johnston (1980) ha empleado con diferente perspectiva "estados de meditación de la conciencia (EMC)", "estados superiores de conciencia (ESC)", "conciencia interna acrecentada (CIA)" y "estados alterados de conciencia (EAC). (de la Herrán, 2006, pp. 1-2)

De esta manera, existen denominaciones paralelas a la de EAC, que pueden abarcarlas o delimitarlas y que manifiestan una diversidad de conformidad con la teoría que pretenda presentar 


\section{SIXÔ ’ Volumen 10, Número 2, 2016}

cada autor. En este sentido, se puede entender que los EAC han llegado a ser una categoría sometida a una amplia discusión, que en muchas ocasiones ha derivado en que sea sustituida por otra semejante o completamente distinta.

En lo que respecta al segundo y tercer aspecto indicados, destaca Méndez (2007) el carácter multiparadigmático de la psicología, que impide una sola teoría para el fenómeno, y la importancia que se ha dado al reduccionismo "fenomenológicopsicologista”, por estimarse que posee respaldo empírico, sólidos cimientos epistemológicos y coherencia interna.

Sobre este reduccionismo en lo epistemológico, el citado autor, muestra la predominancia de la tradición fenomenológica alemana y francesa en la psicología (Brentano, Husserl, Merleau-Ponty, entre otros), puesto que ésta presenta la realidad de conciencia como una bisagra de toda realidad que ni es completamente objetiva ni exclusivamente subjetiva, debido a que, a pesar de la centralidad de la subjetividad en la constitución y vivencia de la conciencia, se sostiene una subjetividad atada a las leyes de la objetividad que constituye (Méndez, 2007). Es decir, la psicología se muestra deudora de la epistemología fenomenológica, la cual delimita el marco conceptual con el que se estiman los EAC.

Paralelamente y en coherencia con la fenomenología señalada, la psicología en lo empírico se ha visto delimitada con los hallazgos de la psicología cognitiva, que valora la conciencia como aquella dimensión conformada por procesos psíquicos (memoria, percepción, atención, comunicación verbal) que permiten que "los datos de la realidad objetiva se alleguen e integren a la estructura de la experiencia consciente subjetiva" (Méndez, 2007, p. 186). 
De esta manera, según Krippner (1990) citado por Méndez (2007), se estima que los estados normales producidos por la interferencia del proceso de sensopercepción y registro consciente vienen a conformar un EAC, que puede ser "reconocido subjetivamente por un individuo (o por un observador objetivo del individuo) como diferente, en funciones psicológicas, del estado 'normal' del individuo, del estado de alerta y de vigilia" (p. 187).

Este paradigma fenomenológico-psicologista con el que se han estimado los EAC ha permitido en ocasiones una valoración positiva de estos estados en contra del difundido prejuicio hacia dicho fenómeno. Dentro de esta tendencia de valoración positiva se encuentra Tart (1969), cuando sostiene que en la cultura Occidental los EAC han sido vistos de forma negativa y generalmente han sido asociados con estados psicopatológicos, omitiéndose así el hecho de la centralidad y reconocimiento que dan ciertas culturas a estos estados. De este modo, resalta la importancia que han teniendo dichos estados en la mística cristiana y en espiritualidades de Oriente, como el Yoga y el Budismo Zen.

No obstante, también dentro de este paradigma prima una posición que no siempre logra diferenciar atinentemente los EAC, de acuerdo a sus causas, mecanismos internos (bioquímicos, neurológicos, fisiológicos) y circunstancias en que se desarrollan, puesto que en ocasiones los EAC típicos de ceremonias de ingesta enteogénica son vistos como un efecto intoxicante y homologables a formas de atención distorsionada de la psicosis, con estados deliroides de la esquizofrenia o con estados meditativos (Méndez, 2007).

\section{b. Clasificación de los Estados Alterados de Conciencia.}

Quirce-Balma (1976) clasifica los Estados Alterados de Conciencia según procesos místicos, esquizoides y alucinógenos, considera los primeros como una experiencia de novedad que 


\section{SIXÔ ? Volumen 10, Número 2, 2016}

es asimilada constructivamente por el individuo, los segundos como aquellos carentes de directrices interpretativas y módulos de referencia para permitir al individuo una asimilación constructiva y los terceros como aquellos, que si bien se diferencian por poseer matices más longitudinales que los esquizófrenicos, en los que falta la trayectoria de preparación para poder concretizar el cambio de forma adecuada.

Sin embargo, después establece otra diferencia entre los Estados Alterados de Conciencia con valor evolutivo, místico y espiritual, de aquellos propios de la esquizofrenia, considera en la primera categoría a los alucinógenos o psicodélicos, en tanto funjan como entéogenos, empatógenos y entactógenos. Comprende los entéogenos como aquellos que producen experiencias elevadas de la conciencia; los empatógenos, son los que generan un profundo sentimiento de unidad con el universo; y los entactógenos, son percibidos como aquellos en los que la persona percibe que "se toca a sí misma por dentro" (Quirce-Balma \& alt., 2009).

Se refiere de este modo a los Estados Alterados de Conciencia con valor evolutivo y espiritual, como aquellos por los que se busca estados de unidad interna para liberación del sufrimiento y de la identificación con los procesos de cambio no transformativo. Contempla estos estados en distintas ceremonias religiosas, en técnicas meditativas, en el uso de drogas alucinógenas o psicodélicas, en sistemas de discernimiento intelectual orientados a distinguir entre lo real y lo ficticio, en sistemas de oración, en cánticos y aún en ciertas formas de danzas rituales (QuirceBalma \& alt. 1988; Quirce-Balma \& alt., 2009).

Sobre esta línea, Quirce-Balma \& alt. (2009) diferencian entre los estados esquizoides y los alucinógenos bajo la consideración del teorema del déficit del portonazo o el Gating déficit, 
según el cual en el cerebro la experiencia alucinatoria presenta una especie de anillo de reciclaje, conformado por el sistema corteza-estriatum-tálamo y de nuevo corteza, que filtra tanto información sensorial como de "regiones primitivas del cerebro", que filtra las alucinaciones e impide un episodio psicótico, posiblemente esquizofrénico, aunque paralelamente permite pasar un mayor grado de información a la corteza.

La remisión a la dinámica cerebral que suscitan estos estados es un recurso utilizado por algunos investigadores como Winkelman (1990) y Mohandas (2008). Winkelman (1990), por una parte, muestra que bajo estos EAC existe un conjunto común de los cambios psicofisiológicos, que implican la sustitución de la condición fisiológica normal de dominancia simpática y de actividad de onda rápida desincronizada de la corteza frontal por un estado parasimpático dominante, caracterizado por una sincronización cortical mediante un alto-voltaje de ondas lentas, actividad electroencefálica originada en área del hipocampo-septal.

Por otra parte, Mohandas (2008) realiza estudios tomográficos de las áreas cerebrales activadas por diversos métodos de meditación y oración, los cuales apuntan a que el cerebro humano con estos métodos presenta el común denominador de una activación prefrontal, hipofrontalidad transitoria, así como un aumento de la actividad del lóbulo frontal y disminución de la actividad del lóbulo parietal, con una deaferentación del lóbulo parietal superior posterior.

También sostiene que la experiencia religiosa puede ser considerada un proceso cognitivo, mediado por un pre-establecido circuito neuronal, que involucra en la corteza cerebral las áreas: dorsolateral, prefrontal, dorsomedial, frontal y medial parietal. Esta experiencia llega a ser religiosa cuando las personas la identifican con su esquema religioso (Monhandas, 2008). 


\section{SIWÔ ? Volumen 10, Número 2, 2016}

Mohandas (2008) sostiene la hipótesis de que los estados mentales, comúnmente considerados estados alterados de conciencia, observados durante ciertas prácticas espirituales/religiosas se deben principalmente a la desregulación transitoria de la corteza prefrontal, donde la hipofrontalidad transitoria es la característica común de estos EAC. Plantea a su vez que existe considerable evidencia de estudios tomográficos sobre la activación de la corteza prefrontal en la meditación y experiencias religiosas.

\section{c. Estados Alterados de Conciencia con valor espiritual}

Para Quirce-Balma \& alt. (1988) los Estados Alterados de Conciencia con valor evolutivo y espiritual están presentes en tradiciones prehispánicas mesoamericanas como la mazateca y la bribri, el cristianismo, el buddhismo, el taoísmo y el hinduismo con variantes como Bhakti o el camino de la devoción, Shankya o discernimiento intelectual, Hatha yoga, Pranayama y técnicas de mantras y tántricas. Se suma así a una discusión, presente desde mediados del siglo pasado, sobre los EAC asociados con la espiritualidad.

Sobre de la indicada discusión, Valiente \& García (2010) consideran que "algunas experiencias asociadas a la espiritualidad han sido catalogadas dentro del elenco de los denominados "estados alterados de conciencia"' (p. 27), pero que logran ser diferenciadas con designaciones más precisas de acuerdo a la especificidad de lo espiritual:

Fenómenos como la experiencia mística, las alucinaciones con significado espiritual causadas por la ingesta de drogas psicoactivas, las experiencias cercanas a la muerte, las experiencias extracorporales, entre otras, llegan a ser incluidos dentro de un subapartado de los estados alterados, bajo el epígrafe de 'estados excepcionales de conciencia', por resultar emocionalmente positivos y deseables. No en vano, 
la intensidad subjetiva de algunas experiencias religiosas específicas ha provocado de que en concepto acuñados por Csikszentmihalyi, sean consideradas como experiencias de flujo; estas suponen una motivación intrínseca en la tarea que el sujeto desarrolla -meditación, yoga, etc.- e implican una absorción total en ella mediante una profunda atención focalizada. (Valiente \& García, 2010, p. 227)

Compréndase que el común denominador de "EAC asociados a la espiritualidad", "estados excepcionales de conciencia" o "experiencias de flujo", subyace en la medida en que se estimen dentro del contexto de la espiritualidad humana. En esta línea Quirce-Balma, de forma similar a Ott (1995, 1996), intenta "establecer la diferencia entre estados de alteración psicótica y estados de alteración de la conciencia que contengan un valor evolutivo y espiritual” (Quirce-Balma \& alt., 2009, p. 89).

Para Quirce-Balma (1976) los Estados Alterados de Conciencia vinculados a la espiritualidad también adquieren un sentido evolutivo en el marco social, en tanto puedan generar directrices culturales nuevas siempre que existan valores sociales-culturales permisivos de la alteración no familiar. La evolución así implica verticalización (ensanchamiento cualitativo) de valores y módulos culturales, mientras que el individualismo implica horizontalización de posibilidades de praxis y conceptualización, lo que resulta, por una parte, que una evolución no sea considerada válida y es enajenada de una realidad cultural y, por otra parte, que la horizontalizadación individual sea válida en estructuras sociales permisivas y reforzantes de la verticalización cualitativa.

\section{Etnopsicofarmacología}

La etnopsicofarmacología constituye una forma de análisis que permite el estudio de la importancia que los rituales y la botánica han tenido a través de la historia. En ella confluyen 


\section{SIXÔ ? Volumen 10, Número 2, 2016}

aspectos de la etnología, la psicología, la farmacología y la antropología, para el análisis de los estados alterados de conciencia desde su base fisiológica (Quirce-Balma, 2010).

Es así como Quirce-Balma (2011) realiza un análisis a la luz de la etnopsicofarmacología acerca de una leyenda bribrí donde intenta dar una interpretación tentativa en el uso de sustancias enteogénicas, en este caso para explicar el efecto de "inversión". Pero, además, Quirce-Balma (2011) indica que para hablar de etnopsicofarmacología "es necesario conocer más que las drogas botánicas y de las ceremonias que acompañan su uso...” (p. 199) y hace crítica de algunos que, según su consideración, hicieron análisis fraudulentos de la temática.

Ahora bien, antes es importante abocar a la historia de la etnopsicofarmacología, donde se encuentra a Eliade (1977, citado en Quirce-Balma, 2010) quien no aceptaba el uso de las drogas psicotrópicas como parte del estímulo al simbolismo; mientras autores como Dobkin de Ríos (2002) y Reichel-Dolmatoff (1977), ambos citados en Quirce-Balma (2010), consideraban que el chamanismo además de aportar sistemas de famacopea de gran importancia, aportan métodos de psicoterapia de gran relevancia.

Mientras que, Winkelman (2008, citado en Quirce-Balma, 2011) consideró que el desarrollo de actividades como rituales, cánticos, creencias, danzas, músicas y drogas a partir de plantas, hicieron una sincronización del hemisferio izquierdo con el derecho y produjeron estados de conciencia superiores que permiten un mayor grado de abstracción, acierto lógico y conductual.

Además, Wasson (1968, citado en Quirce-Balma, 2011) investigó acerca de diferentes culturas con un alto contenido religioso y simbólico del antiguo mundo y de civilizaciones precolombinas, y sus conclusiones implican que la religión como 
tal es consecuencia de los estados alterados de conciencia que se viven bajo el efecto de un alucinógeno, y que entonces, implica más que el ambiente no materialista de dichas culturas o del inconsciente colectivo, ancestral o arquetipal.

Y es que según Quirce-Balma (2011) y su análisis etnopsicofarmacológico, la posibilidad de que los alucinógenos permitan mayor acceso a bancos de información mental o cerebral, que generalmente no se utilizan por parte de la persona, nunca ha sido en su totalidad descartada; y se ha postulado en su proceso que la estimulación con alucinógenos de ciertas vías neuronales, puede dar lugar a conductas creativas como el arte, los rituales, las creencias y las filosofías.

Wasson (1959, citado en Quirce-Balma, 2011) es quien abre la puerta a una nueva época en la antropología etnopsicofarmacologica, al insistir que todas las religiones antiguas basaban su origen en el uso de psicofármacos diseñados a partir de plantas.

De acuerdo con Pokorny (1970, citado en Quirce-Balma, 2011), la interpretación etnofarmacológica es compleja, pues el uso de las plantas alucionatorias se remonta al período paleolítico y su manifestación se dio en un lenguaje mítico y místico religioso que es bastante distinto del lenguaje hablado y escrito de la actualidad. Por este motivo, la descifración resulta difícil, debido a que se trata de lenguajes que actualmente no se utilizan.

Finalmente, desde su etnopsicofarmacología, Quirce-Balma (2011) plantea que se pueden considerar como hechos terapéuticos la mitología, el ritual y el uso de alucinógenos, ya que considerarlos circunstancias de la evolución de la mente de la raza humana por medio de la superstición, es un prejuicio de superioridad del hombre occidental. 


\section{Drogas enteogénicas}

A pesar de la categoría de Méndez (2007), que sigue a Wilber $(1995,1998,2005)$, lo cierto es que el término "enteógeno", que deriva del griego antiguo y que significa "dios generado adentro", por sí solo remite a estados de inspiración poética o profética, generalmente vinculados con lo trascendente. Este término parte de la estimación de que los embriagantes chamánicos no provocan "alucinaciones" o "psicosis" y de la consideración de que la esencia de la experiencia enteogénica es el éxtasis, en el sentido original de esa manida palabra -ek-stasis, "retraerse el alma del cuerpo" (Ott, 2004, pp. 15, 19, 54).

La palabra "enteógeno", por tanto, remite a un EAC con valor espiritual, lo cual también se desprende de la valoración elaborada por Ott (2004), cuando trata dicho estado de la siguiente manera:

Más concretamente, es un estado inefable de gracia espiritual, donde el universo se experimenta más como energía que como materia (Ott 1977a). Un estado donde la existencia es espiritual y no material (Hofmann 1988). (p. 55)

Sobre este particular, resulta insoslayable remitir al papel que ha jugado la etnofarmacología en el estudio de los EAC con valor espiritual, específicamente de aquellos que son propios del consumo de enteógenos. Al respecto han sido destacadas las investigaciones etnofarmacológicas del químico Albert Hofman, del botánico Richard Schultes y del antropólogo Gordon Wasson, quienes conjuntamente y con apoyo de otros estudiosos del tema han abierto la discusión científica en diferentes áreas sobre el consumo enteogénico.

Hofman \& Schultes presentan como "plantas de los dioses” aquellas consideradas alucinógenas o que elevan la conciencia, aunque sostienen limitaciones sobre el uso del término 
alucinógeno o de terminología asociada, como tóxico, narcótico, psicomimético y phantastica, por estimar que "“.."[1]os cambios psíquicos y los estados sublimes de conciencia provocados por los alucinógenos se encuentran tan alejados de la vida ordinaria que resulta casi imposible describirlos en el lenguaje corriente" (Hofman \& Schultes, 2000, pp. 9-14).

Hofman \& Schultes, con la colaboración del etnofarmacólogo Christian Rälsch, presentan una aclaradora obra denominada "Las Plantas de los dioses" (2000), en la que se busca dar una definición de las plantas alucinógenas y una muestra de investigaciones fitoquímicas más relevantes sobre estas plantas, así como su distribución, uso y léxico más generalizado. El texto es una traducción de la obra Plants of the Gods: Origins of hallucinogencic use $(1982,2000)$ por Alberto Blanco, con la colaboración del doctor Gastón Guzmán y del biólogo Salvador Acosta.

Sobre estas denominaciones refieren estos investigadores limitaciones de diverso carácter, como que el término tóxico,

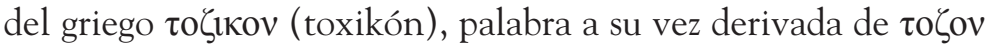
( $\operatorname{arco})$, remite al significado de flecha envenenada y presenta un uso amplio que implica sustancias químicas, vegetales y animales. Por otro lado, muestran las limitaciones del término narcótico (del griego vaркиov), dado que excluye las sustancias estimulantes, siendo más bien el término alemán Genußmittel el que logra englobar narcóticos y estimulantes. Sobre los psicomiméticos (que generan estados psicóticos), señalan el simplismo de tal designación, y en lo que respecta al uso del término phantastica, utilizado por primera vez por Lewin (1924), remiten a que este mismo autor admite que "el término no cubre todos los aspectos que él hubiera querido” (Hofman \& Schultes, 2000, pp. 10-12). 
A partir de ello que se empieza a generalizar la utilización de la palabra enteógeno, como se detalla en los párrafos siguientes.

- Clasificación de los alucinógenos

Según Quirce-Balma y Maickel (2009), las sustancias o drogas que logran la expansión y alteración de la conciencia, que llegan incluso a producir estados alterados de conciencia se clasifican en tres distintas categorías:

\section{Enteógenos:}

Es un alucinógeno que produce experiencias elevadas de la conciencia, entre ellas visiones, audiciones en color, así como sensaciones de armonía y bienestar; el término significa en griego antiguo "el realizar de lo divino en el adentro de cada persona”, y una de sus características es que son principalmente derivados de las estructuras indólicas en estructura química, en vez de ser solamente fenílicas; es el concepto más utilizado para los análisis de este tipo.

Al respecto cabe indicar que la palabra enteógeno (pl. enteógenos), literalmente "dios adentro" por los vocablos griegos que la componen, no está en el Diccionario de la Real Academia Española, pues es un neologismo acuñado por Carl A.P. Ruck, Jeremy Bigwood, Danny Staples, Jonathan Ott \& R. Gordon Wasson, en español aparece en el libro El Camino a Eleusis: una solución al enigma de los misterios (2013, p. 235), de Wasson, Hofmann y Ruck. Presenta un uso generalizado en otras disciplinas, principalmente en la etnofarmacología. Los citados autores la utilizaron por primera vez en "Entheogens," Journal of Psychedelic Drugs, Vol 11(1-2) Jan-Jun 1979, p. 145-146. 


\section{Empatógenos:}

Este concepto subraya el efecto de varios tipos de drogas que producen un sentimiento profundo de unidad con universo, mundo, naturaleza y creación; provocan estados de armonía caracterizados por un profundo respeto y sentimiento de unidad por la vida; ahora bien, no existe mucha investigación en este tema y no se ha podido ligar esta propuesta a una estructura química en el sujeto.

\section{Entactógenos:}

El término refiere a drogas que reproducen estados de la conciencia en los que la persona parece tocarse a sí misma por dentro, este tipo de droga se considera anfetamina alucinatoria, y ha sido discutido ampliamente, es importante señalar que los entactógenos son drogas que fueron desarrolladas en laborales legales en la década de los setenta y que eran consumidos por los llamados "hippies" de la época.

Jaynes (1976, citado en Quirce-Balma, 2010) propone que la conciencia dentro de un paradigma cerebral de actividad neurológica del hemisferio derecho, en dominancia sobre la actividad del izquierdo, tal como sucede en efectos típicos de ciertos enteógenos alucinatorios, posee cinco características.

a. Espacialización: donde las dimensiones del espacio y del tiempo se estiran.

b. Indicación selectiva: en la cual se escogen solamente ciertos elementos del territorio del mapa de la mente.

c. La creación de un yo y un mí de tipo analógico: es una proyección personificada de nosotros mismos, más 


\section{SIXỐ ? Volumen 10, Número 2, 2016}

moviéndose a través del espacio y del tiempo que anticipa el hacer nuestro y el ser hecho.

d. Narratización: donde los eventos son seleccionados por su congruencia y desarrollo secuencial.

e. Conciliación: donde las experiencias son conscientemente asimiladas el uno al otro.

\section{Ontopraxis.}

El término ontopraxis responde etimológicamente a los vocablos griegos őv $\tau$ os, genitivo de ő $v$, ente, que es participio del

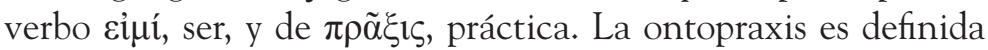
por Quirce-Balma como una dialéctica en la vida humana entre lo familiar y lo no-familiar, con finalidad de transformación de orden ontológica, compréndase a su vez como una dialéctica de cambio individual como expresión de la dialéctica histórica de evolución social (Quirce-Balma, 1976, pp. 23-24).

\section{El Milieu teológico.}

Contra el Milieu materialista, fenómeno de materialización humana, Quirce-Balma propone un Milieu teológico, caracterizado por ser "una época que glorifica al hombre y a su relación con Dios, crea personas más sanas y equilibradas que las épocas materialistas" (Quirce-Balma, 2 de agosto de 2011).

La materialización consiste en tener, para ser alguien en la sociedad de consumo, aunque aclara el autor que "el tener no es algo negativo: si la conciencia también lo es, no existe un antagonismo adonde existe demarcación, a no ser que haya un error entre lo mío y aquello" (Quirce-Balma, 1994, p. 151). 
Quirce-Balma comprende el concepto de Milieu teológico a partir del "Milieu divino" de Teilhard de Chardin, el cual es descrito por Gibellini (1998) de la siguiente manera:

El atributo esencial del medio divino es la omnipresencia divina. Pero ¿cómo se explica esta omnipresencia? M. Barthélemy-Madule, en un estudio comparado de dos obras teilhardianas semejante en su título y en su contenido, El medio místico (1917) y El medio divino (1926-1927), ha tratado de definir el exacto significado del concepto-clave milieu. Milieu asume tres significados sucesivos de los cuales el tercero es totalizante: a) ante todo, milieu significa ambiente, lugar, ámbito en el que existe o sucede algo; b) además, milieu significa medium, aquello por lo que o a través de lo cual existe o sucede algo: significado dia-fánico y mediador; c) y finalmente, milieu significa centro, centro de, y centro que está por doquier: significado totalizante. Es decir, Dios, a quien tratamos de asir a tientas con nuestras vidas, está en torno a nosotros (primer significado); penetra el universo como un rayo penetra un cristal (segundo significado); Dios nos espera en todas partes, en cuanto él es el centro que hace sólido el mundo, el centro que ocupa toda la esfera, el centro que tiene el poder absoluto y último de reunir y completar a todos los seres el punto extremo hacia el cual converge toda la realidad (tercer significado). El medio divino es, pues, el universo en cuanto movido y co-penetrado por Dios en la totalidad de su evolución. (Gibellini, 1998, p. 191)

Sobre el sentido de milieu totalizante, Quirce-Balma establece una época mejor de forma similar a Teilhard de Chardin quien visualiza una alternativa a la experiencia de la Guerra, pues toma conciencia del don o facultad de percibir la realidad y organicidad de las magnitudes colectivas, despertar que percibe en una fantasía un tanto extraña, escrita hacia 1917 en las trincheras y titulada «La Grande Monade». De hecho, los impactos de Asia y de la Guerra, maduran su mística "pan-crística», que se refleja en sus obras La Misa sobre el Mundo (1924) y El Medio 


\section{SIWÔ ? volumen 10, Número 2, 2016}

Divino (1927). Sobre el objeto principal de esta última indica que la pesadilla del pavor ante un final por mecanización termina con el despertar generado por los primeros rayos de un Centro universal de convergencia y de atracción (Teilhard de Chardin, 2002). Este pensamiento adquiere especial importancia en su ensayo La hora de elegir en La activación de la energía (1967), ello en el contexto de la Segunda Guerra Mundial (pp. 15-23).

Al respecto, Teilhard de Chardin describe la misma organización humana en los siguientes términos:

En ninguna otra edad de la Historia, el hombre llegó a estar tan perfectamente equipado y a realizar tantos esfuerzos para ordenar a sus multitudes. "Movimientos de masas". Y no aquellas hordas descendiendo, a riadas, de los bosques nórdicos o de las estepas asiáticas. Por el contrario, se trata ahora del "Millón de Hombres", como se ha dicho acertadamente, agrupado de manera científica. El millón de hombres agrupados en los campos de instrucción militar. El Millón de hombres estandarizado en las fábricas. El Millón de hombres motorizado... Todo ello encaminado, con el Comunismo y el Nacionalsocialismo, hacia la más espantosa de las agrupaciones encadenadas. El cristal, en lugar de la célula. El hormiguero, en lugar de la Fraternidad. En lugar del esperado espíritu sobresalto de la conciencia, la mecanización, que emerge de una manera inevitable, según parece, de la totalización... (Teilhard de Chardin, 2002, p. 310)

\section{Teología intercultural.}

La teología intercultural es presentada por Fornet-Betanourt (2004) bajo los siguientes principios básicos:

- Plantear los supuestos teóricos y prácticos desde un enfoque de la dimisión en lugar del enfoque de la misión (tradicionalmente "colonizar al otro"). Por dimisión, el autor rescata el hecho de que se parte desde el punto de 
la vivencia, del diálogo en su sentido más amplio, la dimisión de los derechos culturales que poseemos y que generan, a su vez, una contracción en la interrelación con el otro; de manera tal que se plasme una vivencia fijada más bien desde la convivencia de las diferentes perspectivas.

- Renunciar al enfoque de la teología de la unidad, reconociendo -y conviviendo- con las diferencias. Decantar a las perspectivas que parten de las identidades que hacen una división entre el registro de lo propio y lo ajeno, y más bien, proyectado desde el sincretismo dialógico y respetuoso. La renuncia incluye, además, la sacralización del origen de la propia tradición religiosa, coexistente con muchas otras, y a la vez, relacionada en mayor o menor medida.

Tradicionalmente la teología dominada por la visión del cristianismo, se plasma con un discurso que más allá de algunos principios propios de esta religión, ha trabajado desde la posición de la colonización del otro, la inculturación hacia una tradición religiosa eurocéntrica, poco abierta al diálogo, y por tanto, a las necesidades propias del contexto actual, en donde se reconoce la variedad interreligiosa y la diversidad cultural como un fenómeno que atañe múltiples contextos latinoamericanos (Fornet-Betanourt, 2004).

Ciertamente la teología intercultural debe este cambio de enfoque a la filosofía intercultural que le plantea retos como propuesta de un nuevo modelo de filosofía y de una racionalidad al servicio de liberar la polifonía cultural latinoamericana (Madrigal, 2008).

La filosofía intercultural parte de supuestos, como por ejemplo que, en nombre de la Historia, caracterizada por su programa de progreso, se marginan y niegan historias, por lo que propone 


\section{SIXÔ ' volumen 10, Número 2, 2016}

un nuevo paradigma de diálogo entre las culturas, en que se intercambien historias, es decir, aquellas memorias culturales que como documentos memorizan otra relación del ser humano con el tiempo. De ahí la estrechez de la Historia líneal para entender el devenir de lo humano en todas sus revelaciones y la posibilidad de que no todo sea Historia, sino de que existan también otros caminos en el tiempo y del tiempo. Motivos por los que dicha filosofía sea ponderada como aquella que es para el mundo, para engrandecer éste y aportar a dignificarlo (FornetBetancourt, 2008).

Por tanto, se pueden extraer al menos tres dimensiones de la teología intercultural:

a. Diálogo y pluralismo: la convivencia de distintas perspectivas y el abandono de la pretensión colonizadora del otro.

b. Atención a la polifonía cultural: en el diálogo se escuchan aquellas memorias culturales como alternativas a la linealidad del tiempo, incluso caracterizadas como no-linealidad del tiempo.

c. Dignificación del mundo: se busca engrandecer éste y aportar para dignificarlo.

\section{Teología tradicional y teología de la liberación.}

La teología tradicional puede entenderse como aquella que parte de fuentes que no crea, se trata de una construcción levantada sobre los loci que da la Iglesia y las Escrituras canónicas (Wicks, 2001). Los loci de la Iglesia son aquellos cimientos o lugares de los cuales parte el teólogo, tarea iniciada en De locis theologicis de Melchor Cano, que se inspiró en el De oratore de Cicerón, y que es continuada por el Vaticano I (1870), Pío XII 
(1950) y el Vaticano II, permeado con la pertinente reformulación doctrinal de Juan XII en beneficio de los seres humanos (Wicks, 2001).

Ciertamente la teología tradicional se inscribe en la institucionalidad, aunque también presenta una implicación ecuménica de acuerdo a las enseñanzas del Vaticano II, pues sostiene que "la teología que utiliza una base eclesial y reflexiona habitualmente sobre lo que el Espíritu dice en las Iglesias también tendrá una sensibilidad ecuménica", e indica sobre el citado concilio la afirmación de "que, las iglesias y las comunidades ahora fuera de la comunión católica, se mantienen y transmiten ciertamente elementos de verdad y medios de santificación" (LG 15, UR 3, 20-23) (Wicks, 2001, p. 155).

Sin embargo, la teología tradicional es bastante omisa de un quehacer teológico caracterizado por un diálogo horizontal con otras religiones y espiritualidades, antes se ve la Iglesia y su tradición, así como que el soporte de la misma subyace en sus fuentes, la matriz del quehacer teológico. A su vez, en no pocas ocasiones se encuentra ausente el tema de América Latina, sus problemáticas y riquezas, y no es posible escuchar una voz que le sea pertinente a esta realidad o a similares, salvo algunas excepciones como en el Vaticano II.

Claramente el Concilio Vaticano II (1962-1966) manifiesta la voluntad de la Iglesia institucional de ser interlocutora de la modernidad, planteamiento que implicó abrirse al mundo con la comprensión de sus esperanzas, sus aspiraciones y su dramatismo, desde un previo y profundo examen de los signos de la época y con una interpretación a la luz del Evangelio (Constitución Gadium et Spes, 4). Desde diversos puntos, entre los que destaca el elemento macroecuménico por el cual la gracia de Dios es extensible a cristianos y no-cristianos -en tanto sean personas de 


\section{SIWÔ ' volumen 10, Número 2, 2016}

buena voluntad (GS 1, 22)-, el Concilio dejó atrás la dicotomía natural-sobrenatural desde la comprensión de la encarnación, razón desde la que se sostuvo teológicamente el proceso liberador de los oprimidos latinoamericanos:

Y al contemplar la realidad en América Latina, el mundo de las mayorías y abrir los ojos a ellas, nos encontramos cara a cara con la injusticia secular e institucionalizada que somete a millones y millones de personas a inhumana pobreza. Tropezar a cada paso con esa injusta pobreza sacudió profundamente los corazones cristianos bien intencionados. Esta experiencia, aunque lejana en el tiempo, permitió acercarnos a la de Moisés ante la situación de sus hermanos israelitas en Egipto: ¡esa situación de esclavitud no podía ser la voluntad de Dios! Y desde la fe en el Dios de Israel comprendió su misión. (Oliveros Maqueo, 1990)

De este modo se enmarca en parte la misión de la Teología de la Liberación, que reflexiona desde la realidad de los pueblos y la fe $(G S 1,11)$, y que también se sustentó en la tradición de los papas como Juan XXIII, tan plausible en el mensaje al mundo antes de la apertura del Concilio Vaticano II, el 11 de setiembre de 1962, en el que se refiriera a la Iglesia de todos y particularmente de los pobres (Bravo-Gallardo, 1993); así como Pablo VI, principalmente en sus respetivas encíclicas Pacem in terris y Populorum Progressio. Posturas que repercutieron en el proyecto de la nueva evangelización que se propusiera en Medellín (1968).

No obstante, es común que la teología tradicional adolezca de un discernimiento de los signos de los tiempos, en lo atinente a las sociedades de conocimiento o al auge en la diversidad confesional. Mayoritariamente es un quehacer teológico eclesiocéntrico y común denominador del cristianismo occidental. 
De acuerdo con Fornet-Betancourt (2007), el cristianismo occidental es solo una forma de vivir el cristianismo, en tanto trata de una tradición monocultural que se ha sumado al expansionismo de Occidente, que afecta, particularmente, a América latina desde 1492. Desde la recepción evangélica a partir de los testimonios amerindios, en los que es posible ver la agresión religiosa, desde la cosmovisión de los sabios mexicas (en remisión a Los colloquios y doctrina cristiana de Bernandino de Sahagún, 1524) y desde la tradición religiosa y profética maya recogida en el Chilam Balam de Chumayel, se constata un cristianismo que corta la historia, no dialoga y causa muerte (Fornet-Betancourt, 2007).

Si bien bastaría con indicar su ligamen con el ritualismo y los aparatos clericales, a la vez que es el cristianismo la constante desde el poder con el cual se conquistó y colonizó América, se estaría ante una definición que puede perfectamente ser objeto de críticas, pues la teología tradicional contempla en medio de dogmas la riqueza de experiencias que se transmiten, aunque no necesariamente son problematizadas, como en sus mismas fuentes o loci, siendo el caso de las Sagradas Escrituras.

De forma distinta, Gallardo (2009) es quien presenta una síntesis de lo que podría entenderse como teología de la liberación, donde se comprende que no se trata de una postura uniforme, sino diversa, pues las variantes poseen metodologías y prácticas diferentes, con la particularidad de remitir al pobre como centro de la discusión y experiencia teológica. La Teología Latinoamericana de la Liberación consiste en un proceso que engloba experiencias disímiles: producción teológica, prácticas pastorales, movimientos extraeclesiales, movimientos intraeclesiales (v.gr. de la Iglesia Católica), movilizaciones políticas (incluidas organizaciones político-militares), Comunidades Eclesiales de Base y otros movimientos liberadores (Gallardo, 2009). Tampoco resulta ser un paradigma sin conflictos y diferencias en 
sus planteamientos, por ejemplo, salta a la vista una considerable diferencia metodológica entre una misa guerrilla con Ernesto Cardenal y la propuesta económica de Franz Hinkelammert. 


\section{Capítulo III}

\section{METODOLOGÍA}

\section{Fuentes:}

De acuerdo con el objetivo general de analizar la espiritualidad de las drogas enteogénicas del mundo precolombino estudiada por Quirce-Balma desde la teología intercultural y después de estudiar las publicaciones de este autor, se escoge la siguiente muestra:

a. Quirce-Balma, C. M. (1994). Señor Dios Príncipe de las flores. Ciencias Sociales, 65, pp. 149-163. En el texto se destaca metafóricamente la experiencia chamánica. Se muestra el estado "normal" caracterizado fenomenológicamente por la contraposición entre lo tuyo y lo mío, que nutre el pensamiento del ser como real y dejar de ser como maldito a ser: el tener de un aquí y un allá en la ausencia de esto o de aquello y el antiser en pobreza. En cambio, en lo 


\section{SIXÔ ’ volumen 10, Número 2, 2016}

alucinatorio, lo engrámico y lo arquetipal, se tiene el sentido en donde se es, fue y será simultáneo: el ser así, mediante la concreción del ser y el antiser. El perder de vista el proceso lleva a la confusión entre lo mío como esto de yo y aquello como esto de vosotros, origen de la falsa demarcación propuesta por la paranoia. De modo que lo nuestro es una lucha entre lo mío y lo vuestro. Dilema solucionado por los incas al establecer el poder como "aquello" donde lo "tuyo" no niega lo "mío", solución que cae al olvido por el "advenimiento del desastre en el pensamiento y el lenguaje adrede de lo experiencial” (Quirce-Balma, 1994, p. 151).

b. Quirce-Balma, C. y Maickel, R. (2009). Los alucinógenos y los teoremas de "Gating" en la acción psicofarmacológica alucinatoria y en la esquizofrenia. Revista Costarricense de Psicología, 28 (4142), pp. 85-99. Trabajo interdisciplinario (psicofarmacología, antropología, religión y botánica) en el que se pretende establecer las diferencias entre los EAC generados por estados típicos de la esquizofrenia y fármacos botánicos, dentro de determinados contextos culturales, sea del aborigen precolombino (también del actual) así como el de la brujería medieval. Se clasifican los psicodélicos y se trata el teorema del déficit del portonazo o el Gating déficit, correspondiente al proceso neuronal cerebral: la corteza-el estriatum-el tálamo y de nuevo la corteza.

c. Quirce-Balma, C.M., Tyler, V. \& Maickel, R. P. (1988). Concepciones culturales de los estados alterados de la conciencia. Neuroeje: Asociación 
Costarricense de Ciencias Neuróticas, 6, pp. 15-30. Se trata de una exposición de tradiciones espirituales que han utilizado los EAC para su desarrollo. Dichas tradiciones son analizadas desde un enfoque etnofarmacológico y neurológico, y entre éstas las que destaca la mística medieval, los movimientos religiosos orientales (principalmente budismo e hinduismo) y las espiritualidades indígenas.

d. Quirce-Balma, C. M. (1976). Estados Alterados de Conciencia. Revista de Filosofía de la Universidad de Costa Rica. Vol. 16 n. 38, pp. 15-24. Estudio de los EAC originados por meditación, consumo de enteógenos y esquizofrenia. Se muestran los mecanismos de rechazo social y de aceptación de la experiencia de los EAC.

e. Quirce-Balma, C. M. (2010). El chamanismo y las drogas enteogénicas/alucinatorias del mundo precolombino. Revista Costarricense de Psicología, Vol. 29, n. 43. pp. 1-15. Análisis de diversas teorías en torno al chamanismo de la antigüedad y actual, con interpretación neurofisiológica de estados alterados/alternativos de conciencia. Contraposición a la propuesta de Mircea Eliade, por inclusión del análisis de antropológico psicodélico. Importancia enteogénica de las plantas psicodélicas de las Américas.

f. Quirce-Balma, C. M. (2010, 7 de abril). Algunas Reflexiones sobre el Chamanismo. Semanario Universidad, 1845. Importancia antropológica del chamán en el paleolítico y el neolítico. Estudio del chamanismo actual, más que todo del amazónico, y 


\section{SWXÔ ? volumen 10, Número 2, 2016}

la discusión científica sobre las capacidades chamánicas. Se contrasta esta posición con la tradición antropológica de Mircea Eliade.

g. Quirce-Balma, C. M. (2010). El modelo arriba y debajo de la conciencia. Revista Reflexiones, 90 (1). pp. 195-214. Explica la trasmutación de dioses a demonios y viceversa, en alusión a diversas culturas. Puede ser considerado un acercamiento a determinada mítica talamanqueña bribrí, a través de implicaciones etnofarmacológicas y botánicas.

h. Quirce-Balma, C. M \& alt. (2010). Los alucinógenos: su historia, antropología, química y farmacología. Psicogente, 13 (23): pp. 174-192. Se estudia la historia, la antropología, la química y la farmacología de las sustancias alucinógenas, desde la Antigüedad hasta la actualidad, pretendiendo ser así la contraparte a posiciones condenatorias del uso ritual y terapéutico de estas sustancias. Se estudia también el "set de anticipación" y tres fases de la experiencia alucinatoria. 
2. Recopilación y sistematización de la información documental.

La información es recopilada y sistematizada de acuerdo con los objetivos específicos, los cuales responden a líneas esenciales de la teología intercultural, a saber:

\begin{tabular}{|l|l|l|}
\hline \multicolumn{1}{|c|}{$\begin{array}{c}\text { Teología } \\
\text { Intercultural }\end{array}$} & \multicolumn{1}{|c|}{ Objetivos } & \multicolumn{1}{c|}{ Quirce-Balma } \\
\hline $\begin{array}{l}\text { Diálogo y } \\
\text { pluralismo }\end{array}$ & $\begin{array}{l}\text { Establecer un primer } \\
\text { acercamiento } \\
\text { dialógico entre la } \\
\text { psicoetnofarmacología } \\
\text { de Quirce-Balma, la } \\
\text { teología intercultural, } \\
\text { la teología de la } \\
\text { liberación y la teología } \\
\text { tradicional }\end{array}$ & $\begin{array}{l}\text { Mundo precolombino, } \\
\text { enteógenos, } \\
\text { etnofarmacología y } \\
\text { Estados Alterados de } \\
\text { Conciencia }\end{array}$ \\
\hline $\begin{array}{l}\text { Memorias } \\
\text { culturales }\end{array}$ & $\begin{array}{l}\text { Distinguir la } \\
\text { espiritualidad de las } \\
\text { drogas enteogénicas } \\
\text { del mundo } \\
\text { precolombino como } \\
\text { memoria cultural }\end{array}$ & \\
\hline $\begin{array}{l}\text { Dignificación del } \\
\text { mundo }\end{array}$ & $\begin{array}{l}\text { Reconocer los aportes } \\
\text { de la espiritualidad } \\
\text { de las drogas } \\
\text { enteogénicas del } \\
\text { mundo precolombino } \\
\text { estudiada por } \\
\text { Quirce-Balma en el } \\
\text { enriquecimiento de la } \\
\text { teología intercultural }\end{array}$ & \\
\hline
\end{tabular}

\section{Procedimientos de análisis de la información:}

En cuanto a los procedimientos se cuestiona cómo se va a analizar la información. Sobre esto cabe indicar que la información se va analizar desde el marco de la teología intercultural, 
desde sus premisas y busca cuestionar los presupuestos teológicos a partir del problema. En este sentido, se ponderan tres campos temáticos correspondientes a los objetivos específicos, mismos que se traducen en tres capítulos, a saber:

a. Etnopsicofarmacología y teología: Este primer capítulo versa sobre un acercamiento dialógico entre la etnofarmacología de Quirce-Balma, la teología intercultural, la teología de la liberación y la teología tradicional. Destaca al respecto el abordaje del consumo farmacológico por parte de la teología tradicional, con los conceptos santidad y brujería.

b. La memoria cultural y la ontopraxis: Este segundo capítulo pone sobre la mesa la linealidad del tiempo en la espiritualidad de las drogas enteogénicas del mundo precolombino, introducción a cosmovisiones que no se enmarcan en la estrechez del paradigma de la Historia con carácter universal. $\mathrm{Al}$ respecto problematiza el paradigma historicista totalizante con el concepto de ontopraxis. Interpretaciones de Quirce-Balma por las que se busca entender aquellas memorias históricas que han sido excluidas de la Historia universal.

c. Milieu Teológico: en este tercer capítulo la espiritualidad de las drogas enteogénicas del mundo precolombino, estudiada por Quirce-Balma, es considerada en cuento al aporte que da a la teología intercultural, pues tanto esta como el Milieu teológico sustentada en esta espiritualidad buscan una dignificación del mundo. 


\section{Primer Capítulo}

\section{LA ETNOPSICOFARMACOLOGÍA DESDE LA REFLEXIÓN TEOLÓGICA}

Un acercamiento dialógico entre la psicoetnofarmacología de Quirce-Balma, la teología intercultural, la teología de la liberación y la teología tradicional, implica que estos campos temáticos, a manera de actores, se acerquen a una misma mesa con la posibilidad de interactuar sobre la espiritualidad farmacológica. Sirva como premisa considerar quién convoca y quiénes han de ser invitados, con el fin de lograr una discusión en que enriquezca la reflexión teológica, misma que versa sobre la relación entre la realidad y lo divino, tratado de ver cómo la religión expresa u opaca la espiritualidad (Avendaño-Herrera, 2005).

En este punto del camino la reflexión se suscita por la teología intercultural que llama a la mesa a la psicoetnofarmacología de Quirce-Balma, la teología de la liberación y la teología tradicional, siendo menester conocer cada una según sus 
características esenciales y sus orientaciones con respecto al objeto de estudio.

\section{A. Un diálogo desde la teología intercultural}

La teología intercultural busca un diálogo con voces o saberes que han sido callados por la Historia oficial, por un discurso que se ha impuesto como válido respecto a otras visiones de la realidad o cosmovisiones (Fornet-Betanourt, 2004 \& 2008). En este caso, antes de hablar de un diálogo con la teología intercultural, es más conveniente hablar de un diálogo desde la teología intercultural (Madrigal, 2008). A manera de metáfora, la teología intercultural es la que prepara la mesa para que dialoguen distintas formas de ver el mundo, en este caso la etnopsicofarmacología, la teología tradicional y la teología de la liberación.

Surgen entonces algunos inconvenientes, con la propuesta de Quirce-Balma, pues si bien se estaría a la escucha de las espiritualidades precolombinas, para ello se estaría recurriendo a un saber suscrito, de alguna forma, a un discurso científico, una matriz revestida de poder, que filtra lo que viene a ser considerado válido frente a visiones "mágicas o primitivas", es decir, es con el discurso de la ciencia de Quirce-Balma que se entienden los saberes y experiencias espirituales derivadas del consumo enteogénico.

En este caso, cabe cuestionarse porqué sería pertinente que en la mesa preparada por la teología intercultural solo se puede ingresar teniendo el visto bueno de la ciencia ¿Acaso no son válidas por sí mismas las experiencias espirituales de corte enteogénico ante una de índole no enteogénica, por ejemplo, una práctica meditativa u oracional?

Por otro lado, cabe cuestionar si es necesario recurrir a esta fundamentación científica para dialogar con la teología 
tradicional o la teología de la liberación, cuando estas no han tenido que recurrir a esta instrumentación para darse un lugar en este escenario dialógico o bien para referirse a lo espiritual.

Ante estos cuestionamientos, cabe indicar que lo que Quirce-Balma devela, como hombre de ciencia, es una bioquímica a nivel cerebral producto del consumo enteogénico catalogándola de forma similar a otras experiencias espirituales (Quirce-Balma, y Maickel, 2009), y que depende de una valoración cultural para que adquiera ese reconocimiento (Quirce-Balma, Tyler, \& Maickel, 1988). De este modo, demuestra que existe una experiencia espiritual, que varía el método, no así de finalidad, y que su reconocimiento depende la sociedad.

\section{B. El uso farmacológico desde la teología tradicional y la teología de la liberación}

La teología de la liberación si bien, como se ha indicado, presenta una diferencia considerable con la teología tradicional, en lo que respecta al reconocimiento de la experiencia espiritual derivada del consumo de fármacos, parece estar en un estado bastante similar a la teología tradicional. El abordaje que se ha dado a esta experiencia enteogénica desde la teología de la liberación ha sido escaso, como en el caso de la Doctrina de Santo Daime (Boff, 2016), dejando dudas si se está ante una reflexión teológica liberadora centrada en el pobre o bien ante un reconocimiento de esta espiritualidad, sin ahondar en cuestiones como represión y censura.

Llama la atención que estas espiritualidades enteogénicas son milenarias de América y propias de pueblos que la sociedad occidental ha marginado y aplastado, pretendiendo borrar su legado ancestral. El cristianismo ha ayudado con esta tarea, en este sentido no se ha planteado una espiritualidad del pobre, y que ha sido negada con éste, una espiritualidad enteogénica. Tampoco 


\section{SIXÔ ? Volumen 10, Número 2, 2016}

es secreto que el pobre en América Latina ha sido conquistado y colonizado, cuya espiritualidad en no-pocas ocasiones ha sido enteogénica.

No obstante, cabe considerar que Madrigal (2008) destaca que la teología intercultural puede enriquecer a la teología de la liberación, permitiendo la escucha de otros saberes y experiencias. En este caso, si la teología de la liberación no ha ahondado suficientemente en la discusión de la experiencia enteogénica puede ser, por un lado, debido a que se han encargado de eclipsar o condenar la teología tradicional y, por otro lado, en repetidas ocasiones, no se le ha dado un valor espiritual a estas experiencias suscitadas por el consumo fármacos. En este sentido, la teología intercultural con el develamiento de la experiencia espiritual enteogénica, por parte de la etnopsicofarmacología, puede enriquecer la teología de la liberación.

La teología intercultural en relación a América Latina propone la ruptura con la monoculturalidad occidental del cristianismo y un alejamiento de la verdad excluyente del cristianismo, no solo en la involución y restauración preconciliares, sino en la misma inculturación. De este modo, la teología tradicional, aun la que pretende una inculturación, es deudora de la agresividad de cristianismo: la carencia de respeto a la diferencia del otro, la instrumentalización de la pluralidad cultural, la corrección de las culturas por el mensaje cristiano, la absolutización de lo propio, el silenciamiento del peso de la historia de dogmatización de la fe cristiana y la insuficiencia de la encarnación en las culturas, para pasar a la heterotopía y heterología de la fe cristiana (Fornet-Betancourt, 2007).

Sin embargo, caben consideraciones respecto a la teología tradicional, si bien bastaría con indicar su ligamen con el ritualismo y los aparatos clericales, a la vez que es la constante del 
cristianismo desde el poder con el que se conquistó y colonizó América, esta definición puede ser perfectamente objeto de críticas, pues la teología tradicional contempla en medio de algunos dogmas la riqueza de experiencias que se transmiten, pero que no necesariamente son problematizadas. La teología tradicional podría tener una relación ambivalente con respecto al uso farmacológico, pues aunque se considere el consumo de fármacos como parte del tratamiento médico o como signo de adicción y por ende de sujeción al mal, en ocasiones los efectos farmacológicos han sido valorados de forma positiva, en tanto ligados a lo divino o lo espiritual.

Sobre esta relación particular es posible derivar de Escohotado (2002), al menos dos grandes líneas, en las que teología tradicional contempla el uso de farmacológico, una relativa a la Sagradas Escrituras, particularmente referida al vino, y otra concerniente a la era cristiana, que comprende aspectos como la brujería y la santidad. Sobre la primera línea, sobresale el vino en la embriaguez de Noé, que acarrera la burla de Cam y su maldición por parte de Noé (Génesis 9, 20-21); así como la borrachera de Lot, que produjera el incesto con sus hijas (Génesis 19, 32).

Sin embargo, el consumo del vino si bien es capaz de generar un estado que es deplorado, principalmente prohibido para los sacerdotes levitas (Levítico 10, 9-11), condenado por determinada línea profética (Isaías 28, 7; 56, 12; denuestos semejantes aparecen en 22,13, y en Amós 6,1) y rechazado por su ligamen al paganismo (Sabiduría 2, 7-8), presenta una valoración positiva, pues es capaz de generar alegría y de hacer olvidar la amargura (Salmo, 140; Proverbios 31, 6-7), a la vez de ser un elemento fundamental en la conmemoración de la última cena, cuyo ágape del pan y el vino se acerca a la esencia del culto a Perséfone (vinculado a los cereales) y Dioniso (ligado al vino), 


\section{SIWÔ ' volumen 10, Número 2, 2016}

que se funden como banquete de pan y vino ya en los cultos de Attis y Mitra, bastante antes de predicarse el cristianismo (Escohotado, 2002).

En lo que respecta a la era cristiana, principalmente en lo que a la Edad Media se refiere, el opio y las solanáceas implicaban un anatema legal, puesto que eran compuestos de "brebajes perjuciales", "untos diabólicos" o "hierbas maléficas", siendo clasificado su uso por parte de la ortodoxia como brujería o contra natura (Escohotado, 2002). También, destaca la tesis de Matossian (1986) según la cual el consumo del ergot (hongo del pan de centeno), uno de los productos del hongo conocido como el claviceps purpurea, fue utilizado tanto por brujas como por monjes, puesto que las primeras lo usaron no solo para alucinar sino para los partos por su efecto vaso constrictor, mediante pulvis ad partum o polvo para el nacimiento (parto), mientras que los segundos por votos de pobreza al no comer el pan de trigo sufrieron los mismos efectos alucinatorios que las brujas, con la salvedad de ser venerados públicamente por su santidad y no enviados a la hoguera como las primeras. Aunado a ello, el consumo del pan de centeno contaminado por el claviceps purpurea producía una enfermedad llamada en ese entonces "ignis sacer" o el fuego de San Antonio (Quirce-Balma, 2010).

Sin embargo, la valoración sobre las drogas por parte de la teología tradicional cambia de forma paulatina de una teoría tomista sobre una intervención física del mal en la naturaleza a una agustiniana que remite a una "ilusión diabólica", que fundamenta lo fantasmagórico de los suspuestos prodigios de las brujas. Esto se debe en parte al abordaje que dan algunos humanistas renacentistas como Giambattista de la Porta (1562), Jan de Wier (1515-1588) y García da Horta (1576), así mismo por el Tratado teológico de Malebranche, Sobre la búsqueda de la verdad (1674-1675), en donde se insiste en la condición simplemente 
vegetal de los recursos brujeriles y la naturaleza puramente imaginaria de los efectos. Aunado a ello, el estudio en la alquimia de los efectos medicinales del opio, por parte de Paracelso y sus seguidores, así como un creciente comercio de opio, conllevan a una distinción entre la farmacología oficial "blanca", que buscaba separar lo puro de lo impuro (Escohotado, 2002).

En el caso de la conquista de México destacan las descripciones de Fray Bernandino de Sahagún, quien en Historia General de las Cosas de Nueva España se refiere a ciertas hierbas que emborrachan y que pretende distinguir de las medicinales, a esa razón cita el ololiuqui, semilla que emborracha y enloquece, producida por la planta cóatl xoxouhqui, el péyolt que causa visiones espantosas, el tlápalt, que también emborracha y enloquece, tzitzintlápatl, con efectos similaresa a la anterior, míxitl, que paraliza, teonanácatl, que provoca visiones y lujuría, tochtetepo, utilizada por los hechiceros y capaz de dañar las tripas, atlepatli, causa la muerte, aquiztli, tenxoxoli, quimichpatli (de Sahagún, 2006).

Los conquistadores españoles admiraron en principio las riquezas botánicas y médicas de América, la admiración y el deseo topó con el perjuicio racial y otros clichés etnocéntricos; toda vez que las drogas medicinales, que también eran psicoactivas, generalmente se empleaban en contextos religiosos o análogos. Esto derivó en una pesquisa inquisitorial exhaustiva contra los amerindios (Escohotado, 2002). Así mismo una droga sagrada para los incas como la coca, fue tolerada por la Iglesia en el tanto se utilizara en las minas para la explotación de los indígenas:

Al amparo de las minas de Potosí algunos españoles fueron aficionándose a la droga personalmente y, sobre todo, apreciando sus cualidades para hacer trabajar más y con menos nutrición a la mano de obra indígena. Era inevitable que los obispos encontraran un modus vivendi pronto, y así fue. Se toleraría el cultivo siempre que quedase condenada su 


\section{SIWÔ ’ volumen 10, Número 2, 2016}

utilización en cualquier tipo de ceremonia religiosa, y se gravaría con un impuesto cualquier transacción. De este modo, si en 1569 un Real Decreto de Felipe II atribuía sus efectos «a la voluntad del Maligno», en 1573 una Ordenanza del virrey Francisco de Toledo legaliza oficialmente el cultivo y determina que el 10 por 100 del valor de las compraventas con esta sustancia corresponderá al clero; a partir de entonces este diezmo constituirá la fuente singular de ingresos más importante para los obispos y canónigos de Lima y Cuzco. La Ordenanza considera que el consumo y tráfico de estas hojas «es necesario para el bienestar de los indios». (Escohatado, 2002, p. 352)

\section{La etnopsicofarmacología de Quirce-Balma}

La etnopsicofarmacología de Quirce-Balma es un marco teórico desarrollado a lo largo de 40 años con el fin de comprender la espiritualidad suscitada por el consumo farmacológico, comprendiendo para ello una relación Biología-Psicología-Sociedad (Quirce-Balma, Tyler \& Maickel,1988); (Quirce-Balma $\&$ Maickel, 2009). Tratase por ende de un estudio interdisciplinario entre biología, psicología y antropología, donde la investigación sobre las funciones bioquímicas a nivel cerebral y, en general, del sistema nervioso, pretende explicar conductas o experiencias espirituales de diversas religiones, aunque particularmente precolombinas en donde el consumo enteogénico ha tenido en ocasiones un papel trascendental (Quirce-Balma \& Maickel, 2009); (Quirce Balma, 2010); (Quirce-Balma, 2010); (Quirce-Balma \& alt., 2010).

Si bien es cierto que la propuesta de Quirce-Balma es predominantemente positivista y cercana a las aproximaciones de Fingelkurts \& Fingelkurts (2009), Hood (2005 \& 2006), Mohandas (2008), Newberg \& Newberg (2005), Nichols \& Chemel, (2006), Roberts, (2006), Roberts (2006), Rogers \& Paloutzian (2006), Spilka (2005), Taylor (2005) \& Winkelman (2004 \& 
2006); considera aristas sociales que muestran el valor cultural que se le da a estas experiencias (Quirce-Balma, 1994); (QuirceBalma \& Maickel, 2009) y (QuirceBalma \& alt., 2010). Ello sin demérito de la propia experiencia enteogénica (Quirce-Balma, 1988), sin que sus investigaciones hayan sido predominantemente enfocadas en el valor experiencial, tales como las de Carlos Castañeda (Robles, 2010).

Sirva como síntesis que la aproximación de Quirce-Balma a la experiencia espiritual enteogénica considera no solo una dimensión positivista, sino que se nutre de experiencias socioculturales y subjetivas, de las cuales surge una valoración de dicha experiencia espiritual que marca cierta innovación. Aunado a ello, considérese además de que se trata de una aproximación desde América Latina, donde la constante han sido estudios de otras latitudes (Quirce-Balma, 2009); (Guerin, \& de Sedouy, 1993).

De este modo, la teología intercultural puede dar con un saber sobre experiencias enteogénicas a las que se les ha negado su valor espiritual y que son parte importante del mundo precolombino. Quirce-Balma (1976) en principio clasifica los Estados Alterados de Conciencia según procesos místicos, esquizoides y alucinógenos, para después establecer otra diferencia entre los Estados Alterados de Conciencia con valor evolutivo, místico y espiritual de aquellos propios de la esquizofrenia, considerando en la primera categoría a los alucinógenos o psicodélicos, en tanto funjan como entéogenos, empatógenos y entactógenos (Quirce-Balma \& alt., 2009). Nótese que contempla los Estados Alterados de Conciencia con valor espiritual en distintas ceremonias religiosas, en técnicas meditativas, en el uso de drogas alucinógenas o psicodélicas, en sistemas de discernimiento intelectual orientados a distinguir entre lo real y lo ficticio, en sistemas de oración, en cánticos y aún en ciertas formas de 


\section{SIXÔ ’ volumen 10, Número 2, 2016}

danzas rituales (Quirce-Balma \& alt., 1988; Quirce-Balma \& alt., 2009). En este sentido, pareciera no existir mayor diferencia entre la espiritualidad inducida por fármacos de otras experiencias espirituales, siendo que varía el método, no así su finalidad, y que su reconocimiento depende la sociedad (Quirce-Balma y Maickel, 2009).

Para Fornet-Betancourt (2007) el cristianismo occidental es solo una forma de vivir el cristianismo, en tanto se trata de una tradición monocultural que se ha sumado al expansionismo de Occidente, afectando particularmente a América Latina desde 1492. Cabe recalcar que se trata de una forma de cristianismo asentado en una teología tradicional que ha negado otras espiritualidades, como la enteogénica. De este modo la pretensión de presentar la contraparte a posiciones condenatorias del uso ritual y terapéutico de las sustancias enteogénicas, mediante un estudio de la historia, la antropología, la química y la farmacología de las mismas, constituye un esfuerzo que permite superar de alguna forma esta negación cultural (Quirce-Balma \& alt., 2010).

\section{Espiritualidad de las drogas enteogénicas del mundo precolombino}

La espiritualidad de acuerdo con la etnopsicofarmacología puede ser comprendida por el análisis de los Estados Alterados de Conciencia con valor espiritual. Quirce-Balma \& alt. (2009) indica que algunos EAC con valor espiritual son originados por el consumo de fármacos. Algunos usos de los psicodélicos o alucinógenos en prácticas chamánicas vienen a poseer un valor espiritual y evolutivo, principalmente en rituales y ceremonias que utilizan plantas entéogenicas alucinatorias, en culturas de América como la azteca y en grupos indígenas del Amazonas. También referencias históricas indican un uso difundido en la 
Europa medieval, en civilizaciones precolombinas y en Asia (Quirce-Balma, 2010).

Los EAC originados por fármacos botánicos y típicos de la espiritualidad humana, también han sido destacados en el enfoque de la psicología transpersonal. En este contexto, Méndez (2007) estima la ingesta ceremonial de enteógenos en el marco conceptual de la filosofía perenne, que juega un papel fundamental en la propuesta psicológica transpersonal de Wilber (1995, 1998, 2005). Incluso Méndez llega a sostener la insuficiencia de la categoría de EAC en el abordaje del fenómeno enteogénico, considerando que es mejor verlo como un "estado no-ordinario de conciencia". Por tanto, al respecto prefiere hablar de un fenómeno de expansión de la conciencia.

De esta razón, Hofman \& Schultes (2000) para aludir al contexto y los efectos del consumo de plantas alucinógenos no recurren a la categoría de EAC, sino que reconocen estados sublimes de conciencia y cambios psíquicos alejados de la vida ordinaria, a la vez que, problematizando el término psicomimético, remiten a investigaciones que comprueban que "las actividades cerebrales provocadas por alucinógenos difieren fundamentalmente de las que se presentan durante psicosis auténticas" (p. 12). Es decir, ofrecen una descripción de los efectos de plantas alucinógenas que puede ser considerada dentro la categoría de los EAC con valor espiritual.

Sobre este estado de conciencia, Hofman (1995) menciona un "gran efecto psicomimético" producido por el consumo de Psylocibe mexicana (una especie de hongo alucinógeno utilizado por los indígenas mexicanos), al experimentarlo en sí mismo. Esta experimentación, realizada en un laboratorio de $\mathrm{Pa}$ rís, lo condujo a visualizaciones sumamente interesantes y con 
resultados significativos en su vida. Así lo describe en un informe del primero de julio de 1957:

Treinta minutos después de haber ingerido los hongos, el mundo exterior comenzó a sufrir una transformación. Todo asumía caracteres mejicanos. Consciente de que al saber yo que los hongos procedían de México tendría a imaginar solamente escenarios mejicanos, deliberadamente traté de ver las cosas que me rodeaban como lo haría normalmente, pero todos mis intentos resultaron vanos. Tanto si mis ojos estaban abiertos como si estaban cerrados, lo único que yo veía eran escenas y colores mexicanos. Cuando el doctor que supervisaba el experimento se inclinó hacia mí para tomarme la tensión, se convirtió en un sacerdote azteca y nada me hubiera sorprendido que hubiera blandido un cuchillo de obsidiana, A pesar de lo serio de la situación me divertía observar cómo el rostro alemán de mi colega había adquirido una expresión puramente india. A la hora y media de haber comido los hongos, cuando la intoxicación estaba en su apogeo, una cascada de imágenes la mayoría de ellas abstractas, cambiando rápidamente de forma y color, empezó a desfilar por mi mente tan fugazmente que temí ser arrastrado por el remolino de forma y color hasta diluirme. Unas seis horas duró el sueño, aunque yo no tuve noción alguna del tiempo. Mi vuelta a la realidad de cada día fue como un feliz retorno a casa de un mundo extraño y fantástico, pero muy real al mismo tiempo. (Hofman, Schultes, Wasson \& alt. 1995, pp. 58-59)

Con respecto al carácter de los hongos para estimular imágenes visuales, Weill (1995) señala que estas imágenes derivadas parecen ser la antesala del inconsciente y, por ende, del sistema nervioso voluntario. Añade a su vez que la visualización viene a ser una técnica básica en muchos sistemas de concentración, meditación y curación, y que la "experiencia del mundo que nos rodea puede estar condicionada, al menos en parte, por las 
imágenes que de él tenemos en nuestra mente" (Hofman, Schultes, Wasson \& alt., 1995, pp. 65-66).

Por la visualización y los efectos que tuvieron los hongos en Hofman, se podría estar ante la descripción de EAC con valor espiritual, pues dista de ser un simple estado de intoxicación o de psicosis inducida (estado cuyo tratamiento sería indistinto desde un enfoque fenomelógico-psicologista), antes se conforma un estado excepcional emocionalmente positivo y deseable.

La tipicidad de que lo descrito sea en efecto un EAC en vinculación con lo trascendente parece estar confirmada con la descripción de otro estado similar vivido por Hofman, cuando él junto a Gordon Wasson se remonta a México e incursiona en la experiencia ceremonial enteogénica con la reconocida curandera María Sabina (quien accede a utilizar el "espíritu de los hongos" extraído en forma de píldoras, entiéndase psilocibina obtenida en laboratorio, pues no había hongos en dicha época del año). La experiencia vivida presentó los mismos efectos que se daban con los hongos sagrados y también derivó en dos predicciones sobre la vida familiar de la esposa de Gordon Wasson, que luego resultaron ciertas, y que en su momento brindaron mucha tranquilidad esta señora, según describe Hofman (Hofman, Schultes, Wasson \& alt., 1995, pp. 65-66).

En este viaje también investiga otras dos drogas mágicas de México: el ololiuhqui, develando así sus principios activos como amidas de ácido lisérgico (íntimamente relacionado con el LSD y otros alcaloides del cornezuelo) y la pipilzintzintli (referida en antiguos códices y en español como "hojas de la pastora"), identificándola botánicamente con la ayuda de una curadera (Hofman, Schultes, Wasson \& alt., 1995, p. 65).

Por otra parte, en el campo de antropología, la discusión sobre este tipo de estados de conciencia ha sido bastante 


\section{SIXÔ ' volumen 10, Número 2, 2016}

desarrollada por Mircea Eliade y Michael J. Winkelman, quienes desde perspectivas distintas remiten a dichos estados en la práctica del chamanismo. La diferencia estriba en que la interpretación de Eliade (1966), que dominara en la antropología nativa durante décadas, niega rotundamente la importancia de los "alucinógenos enteógenos” en la cultura nativa, mientras que la interpretación de Winkelman (2000) indica que las personas que desarrollan rasgos chamánicos han incursionado en una "tecnología de la conciencia", que puede incluir "uso inteligente de la herbología y uso igualmente inteligente de sustancias alucinatorias, etc" (Quirce-Balma \& alt. 2009, p. 2, 11).

Eliade (2009) no utiliza la categoría de EAC, pero comprende el chamanismo como "técnica del éxtasis", estado considerado generalmente en vinculación con lo trascendente, aunque diferencia al chamán de cualquier extático en la medida en que "éste es el especialista de un trance durante el cual su alma cree que abandona el cuerpo para emprender ascensiones al Cielo o descendimientos al Infierno" y quien logra relacionarse con los "espíritus", estimando que un espíritu puede ser "el alma de un difunto, un «espíritu de la Naturaleza», un animal mítico, etc" (pp. 22-23).

No obstante, Eliade (2009) no otorga mérito espiritual a los estados inducidos por narcóticos, pues sostiene que estos son "únicamente un sustituto vulgar del trance «puro»", considerando así que se trata de imitar, por embriaguez narcótica, "un estado espiritual que ya no se es capaz de conseguir de otro modo" (p. 313).

Para Quirce-Balma (1994), la experiencia chamánica puede estar mediada por fármacos. Se muestra el estado "normal" caracterizado fenomenológicamente por la contraposición entre lo tuyo y lo mío, que nutre el pensamiento del ser como real y 
dejar de ser como maldito a ser: el tener de un aquí y un allá en la ausencia de esto o de aquello y el antiser en pobreza. En cambio, en lo alucinatorio, lo engrámico y lo arquetipal, se tiene el sentido en donde se es, fue y será simultáneo: el ser así, mediante la concreción del ser y el antiser. El perder de vista el proceso lleva a la confusión entre lo mío como esto de yo y aquello como esto de vosotros, origen de la falsa demarcación propuesta por la paranoia. De modo que lo nuestro es una lucha entre lo mío y lo vuestro. Dilema solucionado por los Incas al establecer el poder como "aquello" donde lo "tuyo" no niega lo "mío", solución que cae al olvido por el "advenimiento del desastre en el pensamiento y el lenguaje adrede de lo experiencial" (Quirce-Balma, 1994, p. 151).

También de forma distinta a Eliade, Winkelman (1990) utiliza la categoría de EAC en su estudio del chamanismo e incluye el estado enteogénico dentro de dicho estudio. Sostiene la importancia de los EAC en las prácticas chamánicas de sanación y de adivinación, considerando que estos estados pueden ser inducidos por una gran variedad de factores, entre los que incluye el consumo de sustancias alucinógenas, opiáceos y otras drogas.

\section{E. La espiritualidad enteogénica desde la teología intercultural}

Ciertamente la relación entre farmacología y religión ha sido estrecha, el uso de fármacos ha sido usanza en religiones ancestrales del todo el mundo. En el caso de América Latina, este tipo de espiritualidad ha sido condenada por el cristianismo, cuando para los indígenas no había sido objeto de censura, antes las sustancias enteogénicas eran necesarias para alcanzar determinas experiencias espirituales. En este sentido, la teología de la liberación puede considerar también una espiritualidad del oprimido, en el tanto y cuando le fuera negada en la conquista 


\section{SIXÔ ' volumen 10, Número 2, 2016}

y la colonización, mediante una religión que pregonaba cierta sobriedad. Incluso por tal persecución y censura, se ha perdido gran parte de la riqueza cultural y espiritual desarrollada en torno a las sustancias enteogénicas.

Para lo anterior, pueden ayudar las conclusiones de los estudios etnopsicofarmacológicos de Quirce-Balma, que permiten mostrar como a nivel cerebral no existe mayor diferencia entre la espiritualidad suscitada entre el consumo de fármacos y aquella que se logra por la oración o la meditación.

Paralelamente cabe destacar que la teología tradicional dentro de sus dogmas evoca experiencias en las que el uso de fármacos, como el vino, ha sido un elemento fundamental ritualista y de la experiencia religiosa, incluso el consumo de sustancias alucinógenas, como el ergot, ha sido valorado tanto como propio de santidad como de brujería.

Sin embargo, actualmente, la sociedad occidental todavía mantiene una relación ambivalente con los fármacos, pues ha visto en estos un negocio y una cuestión maligna o nociva. Al respecto se ha desatado una especie de simonía y cruzada de forma paralela, puesto que por un lado se comercia con sustancias que alteran la conciencia, que tienen y han tenido una connotación sagrada, tanto a nivel de las farmacéuticas como de los carteles del narcotráfico; pero por otro lado se persigue este comercio ilícito o se censura aquel consumo que modifica la conciencia, siendo considerado el uso para adictos o para personas con problemas psiquiátricos o psicológicos.

De este modo, lo que otrora era una relación con lo sagrado, actualmente es mediado por el capital, sea por una farmaceuticocracia o por narcotraficocracia, con la particularidad de que el capital no tiene que revestir la cosa de alguna magia para lograr su venta, sino de valerse de la magia suscitada por la misma 
sustancia. Esta magia es manejada ya no solo por brujas o chamanes sino también por médicos, farmaceutas y narcotraficantes.

Entiéndase que existe una farmacocracia mediada por relación del capital, en donde el dueño del medio de producción es amo y señor de quien depende del consumo de esta sustancia, dando hasta su vida con el fin de obtenerla. Por otro lado, por convención psiquiátrica se recetan fármacos al enfermo mental, en donde median grandes intereses industriales. A esta razón, nace la simonía del fármaco. 



\section{Segundo Capítulo}

\section{LA MEMORIA CULTURAL DE LA ESPIRITUALIDAD ENTEOGÉNICA Y LA ONTOPRAXIS.}

«La adormidera tiene la propiedad de estirar el tiempo casi hasta el infinito; no el tiempo de los relojes [...] sino el que es enteramente residencia y posesión del hombre, a la vez presente y ausente. Es el mayor de los lujos: tener un tiempo propio» E. Jünger, Acercamientos, 1193 (Escohotado, 1998, p. 415)

La no-linealidad del tiempo es una característica de aquellas cosmovisiones que no se enmarcan dentro del devenir de la Historia, en tanto esta consista en la linealidad predominante u oficial en el curso del progreso de Occidente. Así mismo, cabe destacar que pueden existir otras linealidades históricas, cosmovisiones que tienen otro curso al predominante. No cabe duda 
que, con la Historia, se marginan y niegan historias, aquellas memorias culturales que como documentos memorizan otra relación del ser humano con el tiempo. De ahí la estrechez de la Historia lineal para entender el devenir de lo humano en todas sus revelaciones y la posibilidad de que no todo sea Historia, sino de que existan también otros caminos en el tiempo y del tiempo (Fornet-Betancourt, 2008).

La pluralidad de caminos en el tiempo y del tiempo, incluso la no-linealidad temporal, en nuestra América no ha sido suficientemente abordada desde la teología, siendo la teología intercultural la que interpela sobre este descuido. No escuchar o no querer ver ha sido parte de un legado colonial, en el que las relaciones de poder dividieron el tiempo, al mundo y al ser humano. Se marcó un antes y un después, distintamente a las cosmovisiones autóctonas en las cuales no cabía sino un eterno retorno u otras líneas temporales, elementos propios de espiritualidades en las que el mundo fue y es visto de forma distinta.

Si bien en principio el cristianismo sostiene que el reino de Dios no está en el más allá, sino que se va produciendo en el más acá con la transformación de la humanidad, cambia con el transcurso del tiempo, cuando se hace con el poder, y se convierte en la religión más agresiva de la historia (Hinkelammert, 2003, pp. 113-114). De este modo, llega con la conquista un cristianismo occidental o desde el poder, cuya historia es en esencia la Historia predominante.

No obstante, a lo anterior no por ello puede negarse que en el mundo precolombino hubo relaciones de poder o que existieran imposiciones entre los grupos autóctonos que pretendieran anular determinadas visiones de mundo, puesto que hubo imperios y guerras. La cuestión es que el genocidio de la conquista y la colonia han eclipsado espiritualidades en las que el uso de 
fármacos era fundamental, aunque no por esto puede decirse que toda espiritualidad precolombina tuviese este componente o que todo consumo farmacológico fuera espiritual o ceremonial.

En este punto cabe preguntarse si la espiritualidad de las drogas enteogénicas del mundo precolombino pudo compaginar con ese devenir de la historia o con el cristianismo, posee otra linealidad histórica o bien cabe dentro del campo temático de la no-linealidad del tiempo. Finalmente, si es la ontopraxis una respuesta a este cuestionamiento.

\section{La historia del cristianismo contra la historia de las espiritualidades enteogénicas precolombinas}

Ciertamente, la historia del cristianismo chocó con el mapa religioso de América, con la pluralidad de espirituales autóctonas, entre las que destacan las de orden enteogénico. Al respecto, indica Fornet-Bentacourt (2007), que en la llamada primera evangelización de los pueblos amerindios y afroamericanos, salvo algunas excepciones, el cristianismo no pudo percibir el desafío de las religiones americanas, no hubo diálogo entre religiones sino colonización de almas, con la consiguiente degradación o, peor aún, demonización de los sistemas autóctonos.

La espiritualidad de las drogas enteogénicas del mundo precolombino conllevan una linealidad distinta a la linealidad del tiempo predominante. De acuerdo con Quirce-Balma (2010) es probable que en el mundo precolombino se utilizara preferentemente el hemisferio cerebral derecho, contrario al uso preferente del izquierdo por parte de los europeos. Quirce-Balma recurre a la tesis de Jaynes (1976), según la cual en el mundo antiguo el hemisferio derecho era ejecutivo y pasaba órdenes al hemisferio izquierdo, desde los centros alucinatorios del cerebro hacia el área de Wernicke y estas órdenes eran luego desglosadas por el área de Broca que alucinaba las órdenes del hemisferio derecho 


\section{SIXÔ ’ volumen 10, Número 2, 2016}

para construirlas en voces celestiales. Sin embargo, el mundo antiguo sufrió un cambio drástico con la erupción del volcán Thera en 1500 a.C.:

Dicha erupción destruyó casi toda la cultura del mundo antiguo y hubo que reestructurarlo de nuevo. La reestructuración necesitó del invento de los alfabetos modernos y esto forzó el aprendizaje verbal del hemisferio izquierdo como hecho predominante de la cultura. Antes de ese evento, si bien había escritura, la cultura era trasmitida por el oír y no el leer. Después comienza a establecerse la dominación del hemisferio izquierdo sobre el derecho, hasta llegar a nuestra presente civilización. (Quirce-Balma, 2010, p. 10)

No obstante, Quirce-Balma (2010) va más allá de Jaynes (1976) e indica que probablemente la predominancia del hemisferio derecho sobre el izquierdo se deba a la sobrestimulación derivada del uso alucinógeno y enteogénico, que pudo verse afectado durante siglos por la catástrofe indicada, que dio lugar a la pérdida de conexiones básicas con la India y con la China de donde provenían, el opio (Papaver somniferum), la marihuana (Cannabis sativa) y el rue sirio (Peganun harmala), etc. Así mismo, el conocedor y sabio sacerdocio de las sociedades bicamerales, rico en artes avanzadas de una farmacopea enteogénica, perdiesen las fórmulas más eficientes en el uso de enteógenos y otros psicoherbarios (Quirce-Balma, 2010).

De esto modo la conquista española puedo ser también un choque entre dos grandes culturas, una en la que primara el uso del hemisferio cerebral izquierdo y otra en la que la estimulación del hemisferio cerebral derecho sobre el izquierdo era común por el uso enteogénico. Podría interpretarse como un choque de racionalidades, aunque ello no implique que no existiera un uso farmacológico por parte de la cultura europea invasora, tal como se ha indicado respecto a las brujas y los monjes con el pan de centeno (Quirce-Balma, 2010). 
En todo caso destaca Quirce-Balma (1988) que lo que permanece es el legado que dichas culturas dejaron, de ahí que se debe tratar de comprender cómo esos agentes alucinógenos llegaron a influenciar la concepción de esos pueblos autóctonos, así como su vivencia de la alteración de la conciencia. Sin embargo, desafortunadamente, la herencia de la conquista hizo que muchas de las tribus indígenas sobrevivientes guardaran sus secretos con enorme recelo, a la vez que aumentó la intolerancia de las autoridades de la colonia hacia su utilización. La independencia latinoamericana no logró disipar este prejuicio que se introdujo en la idiosincrasia criolla y mestiza, muchas veces mezclándose con concepciones religiosas de gran mediocridad, que identificaban tales prácticas indígenas (el uso de alucinógenos) con prácticas satánicas o, posteriormente, con prácticas contrarias a la moral y buenas costumbres (Quirce-Balma \& alt., 1988).

Tal fue el caso de los hongos mágicos o teonanácalt, cuya comunión por parte de los indígenas fue considerada por los conquistadores indigna de ser comparada con la Santa Comunión del Catolicismo, siendo incluso que lo que fuera "cuerpo de Dios" para los indígenas se calificara como cuerpo del Diablo a finales del siglo XVI por el monje Motolinía, puesto que expresó que los indios "llamaban a estos hongos "teonanácatl", que significa "cuerpo de Dios", o sea del Diablo al que rendían culto, y de tal manera y con tan agrio alimento recibían en comunión a su cruel dios". En el siglo XVII el culto de los hongos fue declarado idolatría por la Inquisición (Hofman, Schultes, Wasson \& alt., 1995).

\section{La ontopraxis y las espiritualidades enteogénicas precolombinas}

La problemática entre el mundo dado y la experiencia enteogénica es vista como una dialéctica por parte de Quirce-Balma (1976), que es descrita a la luz de la ontopraxis. Aunque el 


\section{SIXÔ ’ volumen 10, Número 2, 2016}

término ontopraxis a groso modo responde etimológicamente a

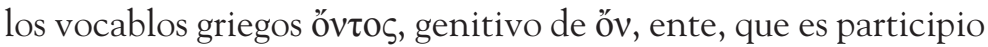
del verbo eỉuí, ser, y de $\pi \rho \tilde{\alpha} \xi 1 \varsigma$, práctica, Quirce-Balma (1976) la interpreta como una dialéctica en la vida humana entre lo familiar y lo no-familiar, con finalidad de transformación de orden ontológico, compréndase a su vez como una dialéctica de cambio individual como expresión de la dialéctica histórica de evolución social (Quirce-Balma, 1976).

Quirce-Balma (1976) comprende la ontopraxis en relación con los Estados Alterados de Conciencia, que clasifica según sean dados en procesos místicos, esquizoides y alucinógenos, aunque después establezca otra diferencia entre los Estados Alterados de Conciencia con valor evolutivo, místico y espiritual de aquellos propios de la esquizofrenia, considerando en la primera categoría a los alucinógenos o psicodélicos, en tanto funjan como entéogenos, empatógenos y entactógenos (Quirce-Balma \& alt., 2009). Nótese que contempla los Estados Alterados de Conciencia con valor espiritual en distintas ceremonias religiosas, en técnicas meditativas, en el uso de drogas alucinógenas o psicodélicas, en sistemas de discernimiento intelectual orientados a distinguir entre lo real y lo ficticio, en sistemas de oración, en cánticos y aún en ciertas formas de danzas rituales (QuirceBalma \& alt., 1988; Quirce-Balma \& alt., 2009). En este sentido, no existe mayor diferencia entre la espiritualidad inducida por fármacos de otras experiencias espirituales, siendo que varía el método, no así su finalidad, y que su reconocimiento depende la sociedad (Quirce-Balma, y Maickel, 2009).

A esta razón, los Estados Alterados de Conciencia adquieren un sentido evolutivo, capaces de generar nuevas directrices culturales en el tanto existan valores sociales-culturales permisivos de la alteración no familiar. Para esto presenta un modelo psicofisicológico que explica estados emocionales familiares y 
alterados, en el cual un aparato propioceptivo (A), que sometido a atenuantes psicofisiológicos ubica la variabilidad interna en límites acordes con la variabilidad interpretativa de la estructura cultural, difiere de uno con un debilitamiento de los atenuantes (B), que permitirá un mayor margen de información propioceptiva, que en ausencia de módulos de entendimiento conllevará a disonancia y despersonalización (B1) y que en presencia de estos módulos da lugar a directrices culturales nuevas (B2).

De este modo, los estados familiares poseen una experiencia de familiaridad, suscitada por estados fisiológicos variables con atenuadores de la variabilidad fisiológica, es decir, una propiocepción familiar, que se traduce en módulos de interpretación congruentes con el historial de familiaridad individual y valores culturales de interpretación del medio externo. Quirce- Balma (1976) recurre a un modo de variabilidad biológica para explicar esta propiocepción, específicamente a la variabilidad fisiológica, causada por fluctuaciones metabólicas y otros procesos fisiológicos, distinta a la variabilidad patológica, causada por enfermedades, y a la variabilidad iatrogénica, causada por actos terapéuticos, incluida la ingesta de medicamentos o diagnósticos (Fuentes-Arderiu, 1998).

Sin embargo, la variabilidad fisiológica está relacionada con la propiocepción, es decir, el sentido que brinda información sobre la ubicación de las distintas partes del cuerpo sin necesidad de verlas (Cosacov, 2007). Ahora esta propiocepción puede ser familiar o no-familiar, dependiendo de los atenuadores, pues si son débiles deja de darse un estado emocional de familiaridad y se genera una experiencia de no-familiaridad.

La experiencia de no-familiaridad puede a su vez darse con módulos de interpretación de la alteración o sin estos, siendo que en el primer caso los valores culturales son permisivos del 


\section{SIXỐ ’ Volumen 10, Número 2, 2016}

estado de alteración y creativamente generan nuevas directrices culturales; mientras que en el segundo caso la ausencia de los módulos de interpretación implican la ausencia de valores culturales permisivos, que conllevan invalidación institucional, y ansiedad-despersonalización, con la consecuente evitación futura de la alteración y el reforzamiento de los atenuadores.

Sin embargo, Quirce-Balma (1976) reconoce que aun cuando una cultura se encuentra estancada por ausencia de valores culturales permisivos, es posible una experiencia personal que marca un distanciamiento con el estancamiento social, derivando en enajenación en un sub-grupo de naturaleza mística o esotérica para evitar la disonancia cognitiva típica de la sociedad estancada, incluso a expensas de sacrificar el potencial de transformación.

Así en un sentido evolutivo en el marco social, se pueden generar directrices culturales nuevas siempre que existan valores sociales-culturales permisivos de la alteración no familiar. La evolución así implica verticalización (ensanchamiento cualitativo) de valores y módulos culturales, mientras que el individualismo implica horizontalización de posibilidades de praxis y conceptualización, resultando que una evolución no sea considerada válida y enajenada de una realidad cultural y que la horizontalización individual sea válida en estructuras sociales permisivas y reforzantes de la verticalización cualitativa.

Para Quirce-Balma (1976), la enajenación en un sub-grupo místico limita el potencial transformador de la experiencia nofamiliar, por lo que propone abrir la experiencia de no-familiaridad como fuente transformativa, esto a través de una dialéctica en la vida humana, entre lo familiar y lo no-familiar, que denomina ontopraxis. 
A) Estados físolóngicos variables
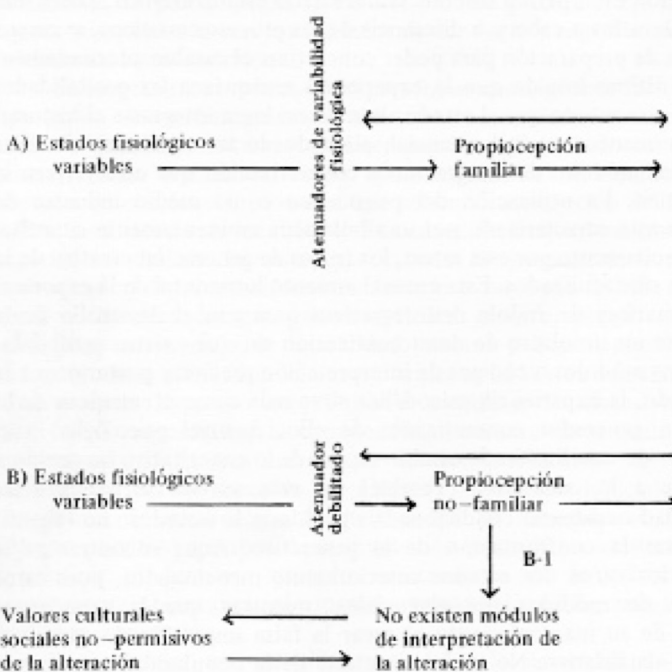

Propiocepción o-familiar

B-1

Valores culturales sociales no-permisivos de la alteración

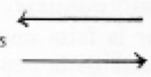

No existen módulos

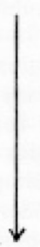

a alteracion

Invalidación institucional

Disonancia coenitiva

Estado alterado de conciencia desintegrativo

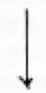
de interpretación de

Experiencia de familiaridad

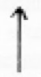

Nivel psico-cognitivo

Módulos de interpretación

congruentes con 리 historial de familiaridad individual

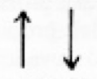

Valores culturales de interpretación-medio externo

Existen módulos de interpretación de la alteración

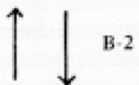

Valores culturales-sociales permisivos de alteración no-familiar.

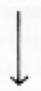

Estado alterado de conciencia transformativa

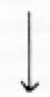

Ensanchamiento creativo de la variabilidad fisio-psicocognitiva previa a ta experiencia alterada

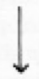

Generación de directrices culturales auevas
Evitación futura del estado alterado

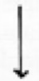

Fortalecimiento de sistemas de atenuación

Figura 1. Modelo psicofisicológico que explica estados emocionales familiares y alterados. (Quirce-Balma, 1976, p. 20). 
La ontopraxis es comprendida en las espiritualidades enteogénicas precolombinas, cuando Quirce-Balma (1994) discurre sobre la figura de Xochipilli, el Señor Dios Príncipe de las Flores:

La relación entre fue y será, también tiene que ser depurada de la relación por error de dejaré de ser para así ser distinto. No se deja de ser, se llega a conseguir una realidad. De ahí que lo alucinatorio puede ser maestro de dotes de cambio. En lo alucinatorio, lo engrámico y lo arquetipal, conseguimos un sentido adonde se es, fue y será simultáneo, a estar teniendo la experiencia de ser así. Pero, ser así es idéntico a todas las formas múltiples que se pueden ser así a través de la concreción de ser y de su antiser. (Quirce-Balma, 1994, p. 150)

Lo alucinatorio del uso enteogénico conlleva una experiencia en donde la relación del ser y del antiser implica no un dejar de ser, sino ser distinto. En el mundo dado el ser y el dejar de ser son excluyentes, de acuerdo con una convención que interpreta el mismo mundo. Sin embargo, con la experiencia tenida de la realidad y del sujeto, mediante drogas será doblada en todo momento de la enseñanza sobre el mundo como una descripción. Lo denominado mundo o realidad es sólo una descripción socializada del mismo y que se introduce desde la infancia en el sujeto. Pero una descripción tan fuerte, tan imperiosa y avasalladora que sustituye la propia realidad (Robles, 2010). 


\section{Tercer Capítulo}

\section{EL MILIEU TEOLÓGICO. UNA DIGNIFICACIÓN DEL MUNDO.}

Dignificar el mundo es una pretensión de la filosofía intercultural, válida también para la teología que dialoga con la polifonía cultural. Aportar para engrandecer el mundo, para que éste sea mejor que como es recibido (Fornet-Betancourt, 2008). En este caso, el diálogo arroja luz sobre la forma como el mundo puede ser dignificado con nuevas directrices culturales. Es la dialéctica entre la familiaridad, ese mundo heredado y construido, y la nofamiliaridad, el mundo espiritual de drogas precolombinas, de Estados Alterados de Conciencia suscitados por la entheogenia; ontopraxis que permite un enriquecimiento del sujeto y su cultura.

La ontopraxis es método que da lugar a un medio para el mundo, para engrandecerlo, para dignificarlo. Este medio es teológico, es milieu teológico. En este medio se conversa sobre la existencia y su propósito, se resiste al aceptar lo existente como 
irreversible y se cree en algo allende al yo. Por ello, el milieu teológico se opone al milieu materialista, que desvincula, que aisla, que afecta el cuestionamiento de la validez de la vida (QuirceBalma, 2010, 7 de abril).

El milieu teológico es una categoría teilhardiana repensada, que dignifica al mundo, siendo que para Teilhard de Chardin, Dios aguarda en todas partes. Se trata de un centro que hace sólido el mundo, que ocupa toda la esfera, que tiene el poder absoluto y último de reunir y completar a todos los seres, el punto extremo hacia el cual converge toda la realidad. El medio divino es, pues, el universo en cuanto movido y co-penetrado por Dios en la totalidad de su evolución (Gibellini, 1998). En este sentido, Quirce-Balma concibe una época mejor, de forma similar a Teilhard de Chardin.

Para Teilhard de Chardin existe una alternativa a la experiencia bélica y a la mecanización de los colectivos humanos, agrupados de manera científica, en campos de instrucción militar y en las fábricas (Teilhard de Chardin, 1974). Teilhard de Chardin remite a esta materialización de los seres humanos mediante metáforas de las ciencias exactas, de la siguiente manera:

Tal como un polvo cuyos granos, a pesar de estar comprimidos, rehúsan entrar en contacto molecular, se excluyen y se repudian, en el fondo con todas sus fuerzas. A menos que, lo que sería peor, su masa se coagule de tal forma que, en lugar del esperado Espíritu, aparezca una nueva oleada de determinismo; es decir de materialidad. (Teilhard de Chardin, 1974, p. 309)

De forma similar Quirce-Balma concibe la dignificación del mundo, a través de un milieu teológico, opuesto al milieu materialista. La salvedad, con respecto a Teilhard de Chardin, es que se trata de la dinámica de la sociedad globalizada de fines del siglo XX y principios del siglo XXI, en donde la socioeconomía 
empresarial fragmenta y atomiza la experiencia humana (Quirce-Balma, 2010, 7 de abril).

Quirce-Balma no enfrenta un escenario de guerras mundiales sino la dinámica de la sociedad capitalista globalizada, de una socialización que niega la persona. Trata como la filosofía y las ideologías de venta/compra y producción excesivas comprenden algo como la ausencia de nada, siendo la normalidad caracterizada entre algo y nada, no así entre esto y aquello. Propiedad de aquello que dio lugar a la avaricia en vez de estar de un aquí y un allá (Quirce-Balma, 1994).

Por ello propone la búsqueda de un mundo mejor y de una estructura más profunda de la teoría de la personalidad, en la que existan nuevas posibilidades no censurables como anormales, en donde lo alucinatorio juega un papel fundamental (QuirceBalma, 1994).

La realidad viene a ser el mundo que ha sido construido por una cultura. Ciertamente en América Latina la realidad ha sido interpretada desde el poder, que posee una lógica con la que se configura el mundo. Sin embargo, este mundo y su lógica son problematizados en la experiencia enteogénica, misma que es nicho de sacralidad y mundos posibles, en donde el ocurrir, como aquella relación entre el tiempo y el ser, es distinto a la realidad:

Por teogonía y teologonía podemos comprender la mitología de las deidades; sus valhallas, olimpos y panteones. Esto hace "sacro" el hecho de ocurrir. Un pasar similar a los calendarios de las "horas" de Europa medieval, los mándalas de oriente y los relojes espirituales ya alucinatorios de las Américas. Lo espiritual y lo alucinatorio a su vez hacían la relación entre "cuerpo" como lo religiosamente capacitado de tener experiencia y ontología como lo impedido de no llegar a seguir siendo tiempo. Si bien lo maya parece generar parte del "día" azteca, también éstos llegaron a tener sus propias incursiones 


\section{SWWO ' volumen 10, Número 2, 2016}

en la "noche del ser" de la civilización. La filosofía que determinó el abrir como dejar de existir creó la "muerte" del ser, mas su muerte fue la economía de un mundo adonde sí hay que vender y guardar, comer y tener sed, edificar, pero no tener sed. (Quirce-Balma, 1994, p. 152) 


\section{Cuarto Capítulo}

\section{CONCLUSIONES}

Un acercamiento dialógico entre la psicoetnofarmacología de Quirce-Balma, la teología intercultural, la teología de la liberación y la teología tradicional, trae como resultado una serie de consideraciones sobre las espiritualidades enteogénicas del mundo precolombino, las cuales tradicionalmente han sido objeto de censura o de ignorancia por parte del discurso cristiano dominante. Así mismo la teología de la liberación podría de alguna forma reivindicar este tipo de experiencias, en el tanto se trata de sustancias enteogénicas que conllevan un valor sagrado para grupos de nuestra América, avasallados desde la conquista.

Ciertamente la teología intercultural permite un diálogo entre el pluralismo, que trae a la luz puntos de contradicción como también acercamientos entre diversas visiones o paradigmas. Si bien han existido confrontaciones desde la teología tradicional o bien descuidos por parte de la teología de la liberación, lo cierto 
del caso es que etnopsicofarmacología pone sobre la mesa la importancia este tipo de experiencias y muestra las ambivalencias del discurso cristiano, que en ocasiones ha oscilado entre lo positivo, entendido como santidad y lo negativo, como la brujería; y que en el caso de la teología de la liberación conlleva un llamado a considerar la negación y condena de ciertas espiritualidades precolombinas, que requieren no solo ser visualizadas sino también reconocidas y mostradas a la luz del martirio.

Cabe destacar que las consideraciones de la etnopsicofarmacolgía de Quirce-Balma, que permite esta valoración teológica, poseen un sustrato científico que históricamente ha pecado de excluyente de otros saberes o formas de experiencias. Sin embargo, las consideraciones etnopsicofarmacológicas se nutren de experiencias socioculturales y subjetivas, de las cuales surge una valoración positiva que no marca mayor diferencia entre la espiritualidad inducida por fármacos con otras experiencias espirituales, como la oración y la meditación, siendo que varía el método, no así su finalidad, y que su reconocimiento depende la sociedad. Así mismo se trata de una aproximación desde América Latina, donde la constante han sido estudios de otras latitudes.

Por otro lado, el acercamiento dialógico propiciado por la teología intercultural trae a discusión el estado actual de valoración de los fármacos por parte de la sociedad actual. Si bien los fármacos han sido parte de experiencias enteogénicas, son a su vez un objeto controversial, en tanto están inscritos en la esfera del tratamiento médico como también en el mundo del narcotráfico y de las adicciones. De este modo, se ha dado por un lado un estudio exhaustivo con el fin de conocer las aplicaciones médicas de fármacos utilizados en principio en contextos sagrados, como también un uso destructivo en la propiciación de adicciones o en un consumo recreativo, alejado de la sacralidad y circunscrito en una lógica de mercado, que produce muerte. Se 
da una especie de simonía que niega lo sagrado y conlleva a la degradación humana.

En este sentido, las memorias culturales enteogénicas precolombinas, valoradas por la etnopsicofarmacología y consideradas desde la teología intercultural, permiten concebir que aparte de la Historia oficial, del devenir aceptado tradicionalmente, existen otras visiones del tiempo y en el tiempo, que Quirce-Balma procura describirlas en la ontopraxis.

La ontopraxis constituye un mecanismo por el cual es posible concebir una dignificación del mundo, es la fundamentación de mileu teológico que busca dar sacralidad y sentido a la vida humana. En la ontopraxis, las espiritualidades enteogénicas precolombinas vienen conformar la base de un cambio social, considerado por Quirce-Balma como una especie de levadura, que recuerda el sentido evangélico del cambio en el mundo. 



\section{Referencias bibliográficas}

\section{Libros:}

Alves, R. (1982). Teología como juego. Ed. Digital. Buenos Aires: Aurora.

Arce-Arenales, M. (2008). La Esfinge y el espejo: Occidente y sus orígenes. San José: Alambique.

Avendaño-Herrera, F. (2005). Introducción a la teología. San José: EUNED.

Cosacov, E. (2007). Diccionario de términos técnicos de psicología. Argentina: Editorial Brujas.

Escohotado, A. (2002). Historia General de las Drogas. Madrid: Espasa.

Fornet-Betancourt, R. (2004) De la inculturación a la interculturalidad. En Tamayo, J.J. y Fornet-Betancourt, R. (Eds.) Interculturalidad, diálogo interreligioso y liberación. (pp. 4360) Madrid: Editorial Verbo Divino. 
Fornet-Betancourt, R. (2007). Interculturalidad y Religión. Para una lectura intercultural de la crisis actual del cristianismo. Quito-Ecuador: Ediciones Abya-Yala.

Fuentes-Arderiu, X. (1998). Bioquímica clínica y patología molecular, Volume 2. Barcelona: Editorial REVERTÉ.

Gallardo, H. (2008). Crítica Social del Evangelio que mata. Introducción al pensamiento de Juan Luis Segundo. Heredia: UNA.

Mena, F., Ramírez, I., \& Rojas, A. (2006). Guía del curso Práctica Profesional. San José: Universidad Estatal a Distancia.

Ochoa, T. R. (2010). Society of the dead, Quita Manaquita and Palo Praise in Cuba. Berkeley: The University of California Press.

Robles, A. (2005). La religión en la sociedad de conocimiento: o el vino nuevo en odres nuevos. San José: UNED.

Robles, A. (2010). Hombre y mujer de conocimiento: La propuesta de Juan Matus y Carlos Castaneda. 1aㅡ edición. Heredia: Editorial UNA.

Segundo, J. L. (1991). La historia pérdida y recuperada de Jesús de Nazaret. Santander: Sal Terrae.

UNESCO. (2005). Hacia las sociedades del conocimiento. París: Ediciones UNESCO.

Wicks, J. (1998). Introducción al Método Teológico. España: Verbo Divino.

\section{Artículos:}

Arce-Arenales, M. (2010). Algunos principios de la Teoría de Dinámica de Tropas. San José: Instituto de Investigaciones en Ingeniería Programa de Investigación en Cognición y Lenguaje, UCR.

Cáceres, A.; Hoyos, A.; Navarro, R.; \& Sierra, A. (2008). Espiritualidad hoy: una mirada histórica, antropológica y bíblica. 
Theologica Xaveriana, 58(166), 381-408. Disponible en http://www.redalyc.org/articulo.oa?id=191015363004> . ISSN 0120-3649

Comblin, J. (2005). ¿Crisis de la religión en América latina? En UNA, Sociedades del conocimiento: Crisis de la religión y retos para la teología (págs. 59-64). Heredia: UNA.

Corbí, M. (2005). La espiritualidad en una sociedad laica. En UNA, Sociedades de conocimiento: Crisis de la religión y retos para la teología. (págs. 13-38). Heredia: UNA.

Fingelkurts, A. \& Fingelkurts, A. (2009). Is our brain hardwired to produce God, or is our brain hardwiredto perceive God? A systematic review on the role of the brainin mediating religious experience. Cognitive Process, 10, 293-326. DOI 10.1007/s10339-009-0261-3

Fornet-Betancourt, R. (2008). Teoría y Praxis de la Filosofía Intercultural. SIWO, 9-42.

Gallardo, H. (2013). Elementos de investigación académica. UNED. pp. 1-17.

Hood, R. (2005). Mystical, spiritual and religious experiences. En Paloutzian, R. y Park, C. (Eds), Handbook of the psychology of religion and spirituality. Nueva York: The Guilford Press.

Hood, R. (2006). The common core thesis in the study of mysticism. En McNamara, P. (Ed), Where God and Science Meet. Vol 3 (The Psychology of Religious Experience).

Madrigal, V. (2008). Una aproximación a la filosofía intercultural de Raúl Fornt-Betancourt: Retos que se plantean a la teología. SIWO, 287-2013.

Mohandas E. (2008). Neurobiology of Spirituality. En A.R. Singh and S.A. Singh (Eds.), Medicine, Mental Health, Science, Religion, and Well-being 6, 63-80. 
Newberg, A. \& Newberg, S. (2005). The neuropsychology of religioud and spiritual experience. En Paloutzian, R. y Park, C. (Eds), Handbook of the psychology of religion and spirituality. Nueva York: The Guilford Press.

Nichols, D. \& Chemel, B. (2006). The neuropharmacology or religious experience: hallucinogens and the experience of the divine. En McNamara, P. (Ed), Where God and Science Meet. Vol 3 (The Psychology of Religious Experience).

Quirce-Balma, C.M. (1976). Estados Alterados de Conciencia. Revista de Filosofía de la Universidad de Costa Rica. Vol. 16 n. 38. pp. 15-24.

Quirce-Balma, C.M. (1988a). Carlos Manuel Quirce-Balma B. World Bigraphical Hall of Fame. Volume II. Historical Preservations of America. INC-

Quirce-Balma, C.M., Tyler, V. \& Maickel, R. P. (1988b). Concepciones culturales de los estados alterados de la conciencia. Neuroeje: Asociación Costarricense de Ciencias Neuróticas, 6,15-30.

Quirce-Balma, C.M. (1994). Señor Dios Príncipe de las flores. Ciencias Sociales, 65, 149-163.

Quirce-Balma, C.M. \& Maickel, R. (2009). Los alucinógenos y los teoremas de "Gating" en la acción psicofarmacológica alucinatoria y en la esquizofrenia. Revista Costarricense de Psicología, 28(41-42), 85-99.

Quirce-Balma, C.M. (2010a). El chamanismo y las drogas enteogénicas/alucinatorias del mundo precolombino. Revista Costarricense de Psicología, Vol. 29, n. 43. pp. 1-15

Quirce-Balma, C.M. (2010b). El modelo del arriba y dejado de la conciencia: análisis etnopsicofarmacológico del uso de plantas enteógenos. Revista Reflexiones, 90(1), 195-214, ISSN: 1021-1209. 
Quirce-Balma, C. M \& alt. (2010c). Los alucinógenos: su historia, antropología, química y farmacología. Psicogente, 13 (23): pp. 174-192.

Quirce-Balma, C. M. (2010d). Algunas Reflexiones sobre el Chamanismo. Semanario Universidad, 1845.

Renart, F. (2010). Fe Antropológica y fe religiosa en JLS. UCUDAL, 1-10.

Rodríguez, J.M. \& Quirce, C.M. (2012). Las plantas y los hongos alucinógenos: Reflexiones preliminares sobre su rol en la evolución humana. Revista Reflexiones, 91 (2).: 9-32, ISSN:1021-1209.

Roberts, T. (2006). Chemical input, religious output-entheogens: a pharmatheology sampler. En McNamara, P. (Ed), Where God and Science Meet. Vol 3 (The Psychology of Religious Experience).

Rogers, S. \& Paloutzian, R. (2006). Schizophrenia, neurology, and religion: what can psychosis teach us about the evolutionary role of religion? En McNamara, P. (Ed), Where God and Science Meet. Vol 3 (The Psychology of Religious Experience).

Spilka, B. (2005). Religioud practice, ritual and prayer. En Paloutzian, R. y Park, C. (Eds). Handbook of the psychology of religion and spirituality. Nueva York: The Guilford Press.

Taylor, S. (2005). The Sources of Higher States of Consciousness. The International Journal of Transpersonal Studies, 24, 48-60.

Winkelman, M. (2004). Shamanism as the original neurotheology. Zygon, 39(1), 193-217.

Winkelman, M. (2006). Cross-cultural assessments of shamanismas a biogenetic foundation for religión. En McNamara, P. (Ed), Where God and Science Meet. Vol 3 (The Psychology of Religious Experience). 
Vigil, J. M. (2005). Crisis de la religión a partir del pluralismo religioso. En UNA, Sociedades del conocimiento: Crisis de la religión y retos para la teología (pp. 65-72). Heredia: UNA.

\section{Tesis:}

Tapia, Napoleón (1993). Psicología de la religión: aproximación teórico-reconstructiva a un modelo de investigación desde Costa Rica. Tesis de licenciatura en psicología, Universidad de Costa Rica. INÉDITA.

\section{Sitios web:}

Boff, L. (10 de enero de 2016). Declaração de Leonardo Boff sobre Fernando, Chico e a Doutrina do Santo Daime. Obtenido de Santo Daime: http://www.santodaime.org/site-antigo/ fardados/espanha/esp9.htm

Oliveros-Maqueo, R. (Diciembre de 1990). Historia Breve de la Teología de la Liberación (1962-1990). Publicado en papel en "Mysterium Liberationis", UCA, San Salvador 1991, vol. I, pp. 17-50 . Recuperado el 12 de Octubre de 2012, de Servicios de Koinonía: http://servicioskoinonia. org/relat/300.htm\#_ftn1

Quirce-Balma, C. (2 de Agosto de 2011). Milieu Teológico. Obtenido de Semanario Universidad: http://semanariouniversidad.ucr.cr/opinion/el-milieu-teolgico/

Vargas Carranza, A. (2013). Los aportes de la pneumociencia de Teilhard de Chardin y de Quirce-Balma para el actual problema de desespiritualización vivido en Occidente. Revista Espiga, 11(25), 79-96. Recuperado de http://investiga. uned.ac.cr/revistas/index.php/espiga/article/view/971

\section{Video:}

Guerin, G.P. \& de Sedouy (Productores), \& Roumette, S. (Director). (1993). Plantas y hombres. Una historia de los medicamentos. El trigo cornudo [DVD]. Francia: GMT Productions. 
[p. $115-$ p. 123]

Anexo

volumen 10, Número 2, 2016 STXÔ ${ }^{9} 115$ 


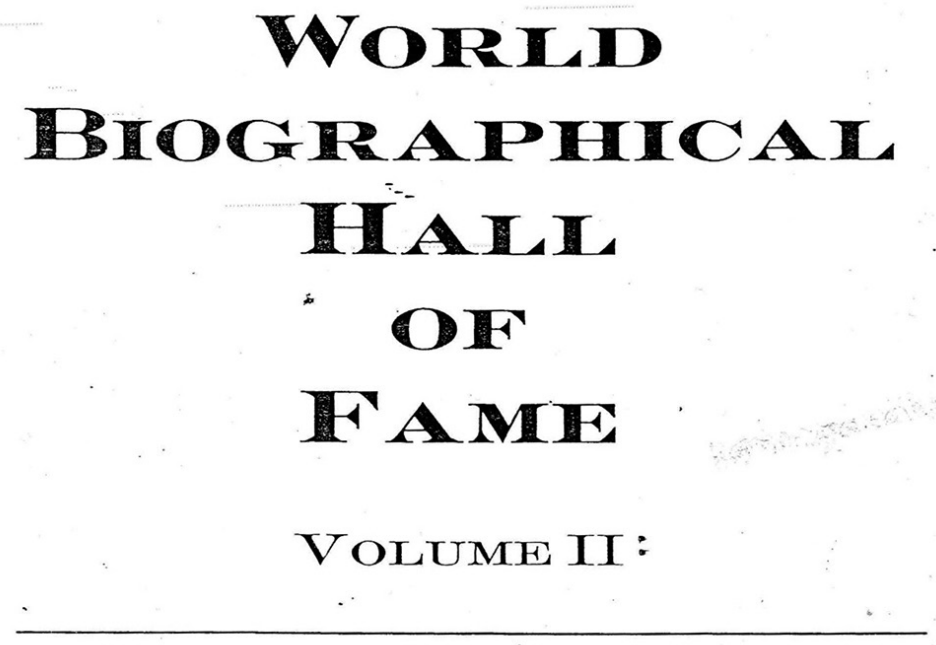

Historical Preservations of Amerrca, INC.

5126 Bur Oak Circle

Post Office Box 31226

Raleigh, North Carolina 27622 U.S.A. 
Copyright $\odot 1988$ HISTORICAL PRESERVATIONS OF AMERICA, INC. AII rights reserved. No part of this publication may be reproduced, stored in a retrieval system now known or to be invented, or transmitted in any form or by any means, electronic, mechanical, photocopying, or otherwise, without the prior written permission of the publisher. The use of this publication is intended solely as a reference work and/or an historical documentation of the lives and deeds portrayed on its pages. The use of this publication as a mailing list for solicitations and/or the use of the names and addresses within this publication as a selection or nomination list by other publishers of biographical works is prohibited and will result in legal action by the publisher. 


\section{SWWÔ ' volumen 10, Número 2, 2016}

for Radiation Protection, the Norwegian Society for Bio-Medical Engineering, the Optical Society of America the European Physics Society and the New York Academy of Sciences, among others. Involving himself in all facets of life, Dr. Prydz as well served Norway through military duty and specialized service from 1952 to 1953. As a brain scientist he has partaken dominantly in extensive studies through many years with significant results As a Human Memory Studies, Remote Brain Control and Cod the of religion, social psychol psychology of religion, social psychology. and functional political systems, from both the theoretical and the experimental approach, as well as studies in heraldry. Over the years, his studies have been faciltated by funds and research fellowships from, among others, the University of Keele, Staffordshire, United Kingdom, the Nansen Foundation, and the Royal Norwegian Council rated studies, have appeared some sixty papers in English and Norwegian, resulting from more conventional experimental physics experiments, published in scientific journals in the United States, Norway and England, and including about twenty popular science articles and newspaper articles in Norway. He has also published a few poems, but most of his poetry remains unpublished. His dissertations were published in 1961 and.1972 respectively (with the Doctor of Philosophy thesis in English), and he holds several invention claims and a patent. In honor of his accomplishments. Svein Prydz Jr. has received Life Fellowship in the International Biographical Association. Cambridge. England; several cultural greetings; and medallic awards of high esteem. He received a Certificate of Merit from the International Biographical Centre for Distinguished Servicê-to the Community in 1979 and for Distinguished Achievement in 1979, 1982 and 1983. He is inscribed upon the Roll of Honour of Men and Women of Distinction (1979) and received the Companion of Western Europe Diploma for Distinguished Achievement in 1982. His biographical data appears in numerous reference publications, among them include the International Who's Who of Intellectuals, International Who's Who in Community Service, Men of Achievement Men and Women of Distinction. Diationary of International Biography, International Register of Profiles and Who's Who in the World.

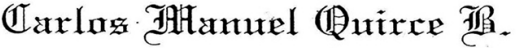

The following is a journey through calm and troubled waters, a biography at heart, mind, body and soul. In the words of Carlos Manuel Quirce B:

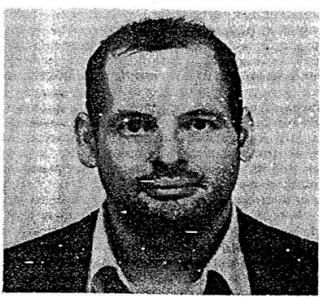

Carlos Manuel Quirce B.

I was born in 1942, in a world rocked by the counterpoint of ideologies. The gentle crib of parent love that did receive me was, however. hardy rocked by the comlagration, and i was born into a happy childhood developed amidst the rockets of a Latin American fiesta, rockets, color. disfraces and all. My memories are mor holonic representations of color, happiness and good will, that transpire through pores of a magical sieve that flies and lights the darkest moments I have since then lived. I felt wanted at my arrival port, and that makes all the difference in one's future. At the age of three and a half, I was, however, to embark with my parents on a iong journey to Now York City where we would live and develop for. the next eight and a half years. Our lourney proved perilous and an almost crash fand and the love of grandparents, but also an entire dimension of being-and_going to another altogether.

My arrival in company of my mother at Idlewild coincided with Halloween of 1945. An adequate party was awaiting us as my father and uncle rushed to the plane bearing jack-o-lanterns and other new symbols of inentification and perchance transtormation. The forms of the phantastic had changed, but the color was stitt there: The color of the magical reality that was the lived perception of my early childhood did not quaver under the impact of subways or even rush hour schedules. It became ticker tape parades, Christmas suspense and Joe Dimaggio allegiance. Yankee Stadium was the alternative symbol of identification to "Gigantes y Cabezudos" or "El Diablo y la Muerte".

My Latin Americanism was the seed that went underneath to hibernate, my North Americanism was the tree that began yiedding fruit that was wholesome as that generation of belief in the young nation I became a part of sang its own praises, not awaiting approval from abroad. 
Even the Korean War was answered by a boyhood that believed in the G.I. Joe of comic books and chewing gum quadrangular stamps. There was abundance everywhere and we lived conservatively but comfortably. An occasional summer in Costa Rica kept alive the hope of those seeds, the "esperanza" that I would discover the misty clouds and vapors of the intensified magic of my native land. A plea and a prayer. I could only sense that there was always some presence there, some Buendia awaiting amidst the countless stories I would always be told by the hired help or parents and adult friends, that saw to it that the lack of TV proved not a motive of imaginative downfall. 1 would always live suffering from a funny feeling, akin to saying goodbye to your future. My grandmother owned a "pulperia" (grocery store) and the characters that filled the place would put Vargas Losa to shame. They were impossible characters, not fitting any television cartoons. My boyhood mind must have stored them somewhere, perhaps in the capacity to laugh for no apparent reason at all, or, for that matter, to feel accompanied even when utterly alone.

1 got as far as sixth grade and Newton's Third Law of Motion. I was to finish that grade in Costa Rica, studying the many rivers of the nation as my imagination and mind's eye focused through the misty veil of the tropical wonder of humid mountains and banks, and of the people that must live there. The Costa Rican boy proved his budding manhood by accompanying parents and "Peones" across sabanas firmly mounted on horseback, often shouldering a rifle. was terrified, but finally survived. High se was terrifi, but finally survived. High schedwasa And yet, I already sensed that this was not the Costa Rica of my childhood or boyhood. Vertical social motion had produced the imitator of the customs of other nations, an aggressive new "crewcut" social class, that in other terminologies would be considered as an unclassed class. Nonetheless, I plowed ahead and my silence grew as anger welled to witness the beginning of the destruction of our own customs. The crewcuts cheered as fevery bolero was substituted by any other song that was not Latino. The rancher sank to become the mark of the unlearned and the downfallen. 1 became morose and kept to myself, taking refuge in my home-chemistry laboratory, the piano, my dog, and astonomical observations, perched in the attic. My grades did nat suffer-from home retreat, and by the age of fourteen, I was reading Thomas Aquirras. and biting at the coattails of Arthur Eddington. Still, socialization finally made an outbreak at the age of sixteen, and I became editor of the high school newspaper. This opportunity lent a passport to the silence as I learned to write my feelings. My senior year crowned my boyhood with the editorialship of the school yearbook My crossedattegiance with the United. States posed an enormouscon That was the an enousconfusionjl saw our customs fall and our customs become imported. That was the size and nature of the confusion. I felt angry at having Costa Rica become the United States, which was what I wanted to begin with and I loathed myself for being myself.

Still, survival meant study, not relationships, and even weekends would find me workina late into the reveries of music, philosophy and science $/ \mathrm{m} 1959.1$ graduated first in my ciass Sand-spentmree months at the University or costa Rica. I had become mystical by then and a religious vocation had flowered. Atso, I had begun to have reiterated altered,consciousness experiences. At the age of 18, I-ailed for Spain to study in Barcetona, at the Chemicall Institute Experiences. At the age of 18, - sailed for Spain to study in Barcetona, at the Chemical Institute in biology. Barcelona was an introduction to refined artistic scare, the studied detail of baroque año classical styles rivaled with the Dali of catalan outbreak. Barcelona was also my first introduction into true nationalism, catalanismo was a serious thing. Several classmates were arrested or had beenin jatfortheir separatism. We sometimes had lunch amidst a conspiratoria air in which catalan was spoken in defiance of government rulations for students during college hours. It was the first time 1 encountered the hush of political fear as the young
men lowered their voices when speaking of their beliefs. f even witnessea a bomb explosion one night near where I lived. Franco's police could be extremely polite with well-attired citizens and tourists, but dissent was their limit and no catalanistas were ever serviced in the police force of Cataluna or Barcelona, as a security measure. At the time I didn't know that my uncle had three death sentences over his head. He had fought in the Spanish Civil War as a student, reaching the degree of "Comandante" in the Lincoln Brigade. I discovered this later after I had left the beautiful exquisite glass bowl of Franco's regional extirpation.

An insistent allergy, which waned and rose in counterpoint with seasonal change, forced my parents to reconstder another country as the seat of study continuation. 1 arrived in New York City in 1961, already enrolled as a freshman at Fordham University. Life was very much alive at Fordham, as we were dealt an avalanche of authors to read, and books to ponder.

I found myself enchanted with the manner of teaching of Jesuitical minds and their preference for philosophy and science. As a fish in water, I assimilatedatt could, even forfeiting lunch hours to read-Russian literature at the university library, I made the Gean's List receiving top grades that year. as well as a scholarship. That phenomenon would not recur until my junior year, and they are the only two prizes I won in college. Still, my senior year brought in its path the introduction of existential theology and of Teilhard de Chardin. Science almost fell to a second row position, as I literally devoured Rollo May, Heidegger, phenomenology and Fromm. The rise in social-consciousness had similarly begun, but the mystical could not withstand a professor of theology dectaring that the sacraments were activations of the

arche sactivations of the

archetypes of the religious subconscious. My universe of coherence came to an end one November evening as the first snowflakes of 1964 fell. I had my first "kundatini" experience
during waking state, as my mind reeled under the impact of disperse but-intense-electrical charges (or so it felt). At the unlikely hour of 10:00 pm, I abandoned my quarters-as idea

piled upon idea, and questioned my very being as a chemist and self of insular profit. walked the campus untri 2:00 am. The next day, I showed, and actually convinced, the Head 


\section{SWWO volumen 10, Número 2, 2016}

of the Psychology Department that the student that was first in his class in chemistry should become a clinical psychologist

twasenamoured with psychoanalysis, particularly a blend of Jungian Analytical Approaches and Existentialism. Had T been adventurous enough to include a psychodelic mysticism, would never have left the William Allison White Institute. Even so, the latter was daily pining. crest of nearly mystical apprehension of showy reaches. Thus I began my struggle with psychometcics and statistics. All the more infuriating. since I was utterly convinced that they were uselossand I was the starving man in the midst of New York psychoanalytical plenty. But you had to have a Ph.D. in order to enroll at William Allison White. Looking back in retrospect, it was the blossoming of the first seeds of magic which I was later to discover. These seeds began to yield the stirring of the ground on which they had hibernated The the arose as un the very structure of education and society. That implied a number of changes in my life. as 1 abandoned my studies increasingly in obedience to a greater call within, which I knew to be that of my own destiny. It is difficult to let go of one's own sense of direction and accept the dance of Shiva Nataraja, the dance of destruction and one's apparent plans, as the unexpected takes on greater force. The summer of 1066 saw me leaving for Mexico, the most beapectiful trip trip consisted in spending three months in a small Mexican Village and serving the health trip consisted in spending three months in a small Mexican Village and serving the health. and and its people began speaking to me as the gods of Mexico played their magic on me. The extremety serious academician became the serious, dedicated social worker, and then the adventurer seeking treasure in ancient Palenque and Uxmal. The people gave me a taste and remembrance of those first three years of life in Costa Rica. The red and brown humor

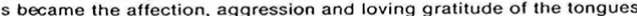
of speech of its people. We were serenaded at the end and an army contingent escorted us to the surprise party that night: complete with piñata and mariachi. The color had returned the joy. the magic, and timeless time succeeded the presence of schedules. The. "maestro de obras" who was wanted in some other province by the law for a passionate "crime, the man who taught us how to build houses and repair bridges, the padre that went around armed with a 38 calibre pistol, just in case the revolution broke out again and his mother, who still remembered the bombing of Veracruz and hid behind the curtains when she heard that the "gringos" were coming; all were in attendance. We were still the children of good intent. We believed that effort and good would change the world. All we needed to do was apply ourselves and the obstactes would melt. The raised and clenched fist of defiance was still not necessary. We were holy crew cuts. The return to the world of problems met us with a blast. norsoftened by the partial return via Costa Rica.

I became disgusted with graduate school jMy professors seemed fools in comparison with the magic of "Potrero Grande. They spoke of-what they had not experienced. I had almost the magic of "Potrero Grande. They spoke of-what they had not experienced. I had almost the courage of two young townsmen that waded the flooded river to reach my drowning body. And here were stuffed mothballs telling us about social psychology and other events in dry abstracted detachment. The clenched fist rose as I walked out of class one day in a flurry of defiance and met the age of discontented ex-seminarians, Greenwich Village characters and Karl Marx. The clenched fist stayed in place as I swore to bring down the characters and Karl Marx. The clenched fist stayed in place as

Chicago of 1968 saw the first encounter with urban terrorism waged by a police force against dissent. The very same party that had broken its paradigm by electing John $\bar{F}$. Kennedy was to clese its deers on what they called radicalism, but which, for us, was the right to be magical, to demand the existence of the impossible as solution, instead of the impossible as problem. Dogs, tear gas, cattle prods, batons, night sticks-the sttuation was desperate, presenting a-tult-scale revolution before we were ready to handle-it-successfully.

The assassination of Bobby Kennedy further convinced me that we were living desperate. mations, Martin Luther King died for our incapacity to find impossible solutions faster than the impossible problem of our death in life, called alienation, called pigeon holing. called ignoring not only the poor of pocket but the poor of mind, of soul, the dead of spirit, the seedless. The giutters of Park Avenue filled our hobo sacks with gists of Santa Claus. Our returns of the day were the ones that unlike Vicktor Frankl had not survived the death camp promise un beter living of the system and its dying promise of better living through standardization of heart and soul.

I left for Indiana University, as New York had become my Dachau. I could survive no longer amidst those eyes in the subways and streets, the beggars of solutions and spirituality. The empty sockets of soulessness had finally defeated even the seeds of magic. I was losing my childhood belief in my destiny, in myself. Indiana was more than the heartland of America, it was Norman-Rockwell with a soul. The people were not friendly, they were innocently giving. They actually experienced sexual pulsation without quoting Freud or minority rights. The They actually experienced sexual pulsation without quoting Freud or minority rights. The
toughs were utterly toughs because they were people, the silent ones really were worried. No one was out to blame anyone else. It was paradise without original sin, without malice. The seeds began to bloom again.

Indiana University was filled with people that had never apparently commited original sin. It was impossible, but then I was searching for the impossible. My New York self could even inform them of the existence of complexity without causing harm. It was a mission, albeit somelimes trying.as bewidered blue eyes met words of caution and perplexed freckles greeted 
my more semitic attitude towards the revolution. Still, I grew to love them. I may have taught some to love, for love never existed in paradise. just the TAO of preterinatural gifts.- Ta love one repents and jumps the gap of the impossible separation that offense has produced. Love is the irrationality of grace; to exist, primary separation is necessary. It is post-paradise.

I was helped substantially by friends from California that somehow had more Oaxacan I was helped substantialiy by friends from California that somehow had more Oaxacan
attitudes that I could muster. I was psychoanalytical, Marcusian, Catholic and semitically attitudes that I could muster. I was psychoanalytical, Marcusian, Catholic and semitically Che Guevara as a Latin American. White skinned deva-like creatures brusthed by my colorful New York attire. Normality passed by paranoidical lovingness that wanted change through violence, if necessary. I was living in the United States of America and it wasn't my birth nation. Why? I had realized that the United States was an exploited nation, both internally by its own system as well as abroad. It didn't yet have its own tradition as a young nation. Its kulture-complex towards older nations made it naively arrogant or freckled innocence. I had integrated that much in my mind. The first two years were dedicated to brain biochemistry and cyclic AMP. The Mahler/Moore brain group was an elite ruling class amidst researchers of the new frontier. I was proud to have both their patriarchal approval. And yet I could not forget the magic. I switched to Roger P. Maickles psychopharmacology group and joined the Transcendental Meditation Movement. Maharishi Mahesh Yogi took an interest in me, the Transcendental Meditation Movement. as I began to complete my education with the Understanding of Hinduism, especially the Veda. Enlightenment as a solution to sin was a new alternative. It was a different path from that of endowed grace. One obtained it oneself. It was heaven but it was also paradise. Hallucinogens and meditation became the obsessive synthesis as I put catholicism in the safe for awhile. I had read the riot act to my catholicism and its need to postulate evasion of $\sin$ as the motor force of repentence and encounter. Gigagtes y Cabezudos once again danced in front of my eyes and La Muerte y EI Diablo were no longer to be avoided in an agonizing soul search for grace and redemption. Holiness as the natural state began to sink into the Latino. New York religious neurotic mystic gone revolutionary. Strangely enough, I exchanged cyclic AMP for stress research instead of going the Oaxaca path. Why? Something told me to hold off. The time would come. It would be ripe for chemical neuroendocrine salvation, where you and $I$ would be one because we were two. Thus stress it was and then it dawned that I had discovered a form of cellular functioning that was ahomeostatic, almost cancer like. A maintaimed perturbatromin feuroendocrine and biogenic amine functioning.

cancer like. A maintained perturbattonintheuroendocrine and biogenic amine functioning. thesis that it was a sieve of vortice nature in the heart of cellular interaction. It was siphoning off enthalpy and transforming enthalpy into entropy. It was responsible for disease proneness and lay at the basis of psychosomatic illness. My doctoral thesis established the experimenta1 data for the theory of nonhomeostatic macrocellular functions. Maharishi called me the man that had discovered stress. I finished my training as an instructor of TM in La Antilla, Spain. The Maharishi's parting words to me were: "O back to Costa Rica become a researcher The Maharishi's parting words to me were: "Go back to and a scholar, and spread Meditation from that point of view." T proceeded to do that. It was March of 1973 when my mother greeted me at the airport of San Jose, wizened, mysterious and always knowing something no one else was privy to. I began initiating heards of persons as I reached enlightenment in 1984. My enlightenment collided head on with the terrible "wby". of Latin Amefica, becoming ideological in the university setting. The "why" of Latin America is the questionititg of the brown-eyed people on the earth, the wretched of the earth, the why must we be the ones to suffer, does Calvary never end for us P Rorque nosotros? pleaded the brown faces and the searching eyes of the children. Porque nosotros? All my training in Christianity, Shanchara's Holy Tradition, radicalism and the sense of magic were unable to answer the terrible question. I began to go insane. I was enligintened and yet could not live up to the demand of the times. It was impossible. The silent "porque" of the people became the vociferous demands of the ideological left of the universities as being an initiator was screamed down as bourgeois solutions, as betrayal, as the opium of consciousness. My enlightenment was offered on the altar of the terrible why. I understand now. Then I left agony, incomprehension and hostiity. I had thought 1 had solved the entire realm of human possibility by soiving the yearning of my hridayam, of the heart. Here was a problem that was the agony of the heart. The heart of the poor of the earth. The questioning, bewildered heart. The direct heart that suffered martyrdom without a choice of heroic acceptance of the martyrs faith. Which is the greater saint, he that accepts by his affirmation his lot having the choice of the full pleasures of the world or he that is condemned from binth to that lot without any choice whatsoever? I had met the ones that were innocently condemned. I could not but suffer a similar lot.
My enlightenment vanished, I joined appropriately the Third Order of St. Francis, the path of the poor. the Poverello of Assisi. My solution then became, let us accept the nothingness of our lot. Let us not seek another lot, let us manufacture our own destiny. If the terrible why of our absence of better still vacuum remains unanswered, let us have the courage to refuse ourselves as the negation of decision. Perhaps we were collectively condemned to the privation of the wealth df nations, but that wasmot the privation of the wealth of nations, but that was mot-synonymous with the condemnation of our will to forge our presence. Accepting our nothingness, we have taken the first step to affirmation, with that we can begin to be. That, then, is the new "why". From nothingness to allness, through the acceptance of our poverty. It is impossible, but only one impossible ,can answer another. Let us then, without practically any equipment, produce the most advanced theoretical and experimental frameworks of all disciplines. Let us jump ahead of the wealthy by this impossible route Let us transpose impossibles. We have nothing to lose, at least that is in our favor. That was the basis of my speech of acceptance of the directorship of 


\section{SIXO volumen 10, Número 2, 2016}

the Psychology Department and the advice I gave my assistants in those days and still do. The raised and clenched fist can become our leadership of the world, rather than foolish destruction of the little we have by further turmoil. Our accomplishment must be our anthem. our doing must be our revolution. Its very existence is our revolution, is our Chicago 1968 . our Cuba 1959. And in the end we shall win bectuse we have improved the lot of all mankind. rather than prove that we had more muscle than our oppressors, be they who they be. We Witt -rot seek approval or rejection. The words of St. John of the Cross came to mind: "Ni buscare las flores, ni temere a las fieras." Neither shall we be moved by sincere or adulatory acceptance nor depressed by scorn, mockery and derision. We will not stand still and be found. We will forge our path through the jungle. Take my hand and I shall take you over the mountain, little one.

It was all I could do, it was the words of the Poverello, come to my consciousness. It was then 1 launched a research program in the Psychology department, which culminated in elaboration of a master's program, several laboratories, and my own research facilities. Several scholarships for Costa Ricans became available as I began to publish. Two assistants and fifteen immobilization cages formed my only equipment in 1976, as I plowed forth to prove that the Selysian paradigm could be substantially improved upon. The unhomeostatic macrocellular theory of function became as reality as ever more evidence was gathered that macrecellular theory of function became as reality as ever more evidence was gathered that substantiated the claim of my doctoral thesis. I formulated and attained a maintained stress Latinoamericana de Análisis y Modificación de la Conducta) Conference held in Panamá in 1977. I was applauded by such luminaries as Rubén Ardila and Miguel Angel Escotet. Thalassinos of Panamá applauded my work and nominated me for treasurer of the association. I was elected and left Panamá with joy. My assistants met me at the airport as tears rolled out. We had won! We had begun to prove that we could win going from nothing to everything. Furthermore, the interest of nations such as Venezuela, Colombia and others were upon us. Furthermore, the interest of nations such as Venezuela, Colombia and others were upon us.
The applause had been shattering, the interest keen. We proceeded to celebrate as only a latino can; we drank as offering of our joy. We woke to the reality of furtherance. We could not but continue. Finally researchers in the United States and Europe took an interest in our work as well as the National Science Council of Costa Rica. Our funding increased and the story and soon I was being interviewed by newspapers from abroad. The point remained, was I furthering the work of others? Yes, the answer was statistically proven. My challenge and oath had spurned the other researchers to reject the barrier of "I can't because I don't have the means to." The "Let us fabricate the means" became a familiar quote at the university.

I afso wrote in the social sciences and furthered dependency theory by postulating psychological consumerism as the main variable of false consciousness, instead of production psychological consumerism as the main variable of false consciousness, instead of production "teoria de la dependencia" had stated. Three articles appeared in the Journal of "Ciencias Sociales" and "Estudios Sociales Centroamericanaos," another was sent to the prestigious Venezuelan journal, Interciencia. The works which appeared in Estudios Sociales Centroamericanos caused an impact in the theoretical wing of the left and even Brazilian thinkers as well as Chilean scholars began a dialogue regarding its contents. D'Arcy considered it relevant since it ontologized the revolutionary process without becoming idealistic. A. Campos from Chile considered its importance in the study of prison populations that might reflect from Chile considered its importance in the study of prison populations that might reflect revolutions in their countries. At least I had proven that I could speak intelligently to the Latin American left, without arising accusations of counter-revolutionary attitudes and subversion of change.

1978 witnessed my trip to Purdue University in the first attempt to establish a link between my group and their research facilities. The National Science Council of Costa Rica (CONICIT) was keenly interested in that liaison; it was their policy to form such contacts and build those bridges. Thus my trip had political implications, at least as a politica! format of inter-hemispheric collaboration was implied. I was received well at Purdue, in an atmosphere as only North Americans can produce: curiosity, excitement, and a sense of participating in the foreign as a standout of their daily lives. The foreigner often becomes the archetype of the unusual that holds secrets privy to others ways I presented our data, and amidst an atmosphere of initial disbelief, the scientific mind began to question its feasibility. I was expecting the disbelief. After all our revolutionary promise had established the strategy of the attainment of the impossible by the acceptance of our own negation. That was the only form of answering the terrible why of the poor of the earth. The situation developed well, for instead of permitting my pride to feel offended by the scrutiny. I let it proceed, in the knowledge that the situation would change, as it did. Soon, I began being reinvindicated through their increased interest. The pulse of the wave reached it maxima in 1980 at the ASPET meeting held in the Mayo Clinic facilities. We presented seven papers. more than any other group. The Costa Rican experiment was commented on in the ASPET report on the first page of their newsletter. Further attainment became the prize awarded to me in 1981 at the Chicago International Radiopharmacology meeting.

However, my magical sponsors had other thoughts in mind as I returned in laureled fame to Costa Rica The myself in the most intense personal experience of the invisible present I ever had. My own dynamics clashed with the magic of the gods, as I reeled in the attainment of a new enlightenment of presence. I called it the enlightenment of the ascending. It was in some ways the culmination 
of my idea of attainment of all through nothing. However, I was ready yet not ready. 1 came out enlightened but confused. There was no logical explanation at the time. I had to formulate a new logic. Paranoical formulations abounded as I began with the path of fear. The path of fear is the path of Adam. Rather than become the god of the experience I reached towards Adam and became the fear of retribution. The Adam expelled from paradise that flies into history and takes refuge in the pitgrimage of time in the presence of the wrath of God. And yet I was god and man. My own blend of the impossible. In difference to Christ, I was fearful man and superseeding god. The synthesis produced a sign of contradiction so strong that I felt the ultimate know of the universe. I began to change my interests and the path of Oaxaca finally revealed itself. Love through hallucination and strength, through fear, became my salient characteristics. I praised a god whose hand would not hestitate to render punishment. I was the god and the condemned. And yet I refused to accept both; thus I protected them outwards, leaving me as the witness of the fear and the stength, the love and the vision. I became aware of what projection truly means.

A forthcoming paper will treat this subject and will be submitted to Neuroeje, the Costa Rican neurological journal. The witness became the saint that stood in judgement of the man and the god. My life and interests gyrated towards altered consciousness with rapidity. In some_ways, I was a luciferean saint, for I judged the god as well as the man that was judged by the god. That was my first embodiment of the luciferean archetype. I found that Lucifer was capable of greater love than the god of condemnation I had learned to fear throughout my education. Lucifer could understand what the deity could only condemn. It was Prometheus sitting in judgement of both Zeus and the ingratitude of a humanity that never thanked him for the gift of fire nor the sacrifice that entailed for him. The luciferean saint was the promoter of the path of Mesoaerican precolombian magic, plant derived hallucinogens and psychiopharmacological exploration of consciousness. The lućciferean devoured knowledge of medition, methods of enlightenment as it defined light as that derived from fire, not from (1) god-like radiance. The igneum in me triumphed, as I went to the United. States as a Fulbright
Fellow to study altered states of consciousness. Purdue University greeted me well and soon 1 had rewritten my proposal there to fit my new interests. An entire year was devoted to reading and learning in the Oasis lunch soda of the Campus Center. Still something held me back from attaining a permanent position in the United States. I returned to Costa Rica in 1983. Greeted by a silent mother, whose eyes spoke of things to come, I engaged in pure igneum and pure arian work. I had discovered that the true arians were our Indians, the browncolored people. Still I called it blond research. The results were amazing, and I began to discover the secrets of ancient civilizations by intuition. I was transported to the time site by Brunca spheres and other engrams. I began living at the appropriately-named Bellavista Museum. It was a converted fortyess, where my grandfather had been commanding officer during the first quarter of the twentieth century. Luciferean of the left hemisphere met luciferean of the right hemisphere. The story unfolded in such exquisiteness that 1 became a seer of the incredible. My writings of the times, rejected by several journals, were too revolutionary. i proposed a universe in which light as both grace and corpuscular wave would not return 1 proposed a universe in which light as both grace and corpuscular wave would not return
to its point of origin but rather break the barrier at the end of matter and energy and travel into nothingness. I was criticizing the Einstenian curvature of space and time.

Several homes later (we moved every year), I settled in a haunted house (where I presently live). University officials looked on in worry as their resident "enfant terrible" became a parapsychologist. The turn was all too muci to bear as I began holding conversations with thin air in their presence, I stated that I had found new forms of energy, of mathematics, of matter, that we could transport matter across time and space instantly, that space was of matter, that we could transport matter across time and space instantly, that space was of their capacity to understand the beauty of the worlds I had discovered, I spoke of the return of the gods and the return of the Great Mother. I spoke to them of the experience I was having in darkened coffee plantations, of the new mathematics I was trying to formulate. Of materializations of the ancient Inca, Chimú, Aztec and Toltecs, of Maya and others. They reeled under the impact of several fields of knowledge being discussed in the same convergent theme. Some began to listen, others remained bewildered. I told them that our heritage was by far the most advanced. We could have a space program in years if we could decifer the engrams of the ancient Zapotecs or Incas. That proved too much, and I was asked to tune in and tone down for the sake of the reputation of my past work and for the institution as well. I began to stay at home more and more, with their blessing, but without any financial backing. Fortunately, I had learned to use nothingness. From the heights of fame. I had plummeted into ignonimity. One day my patron saint appeared, St. Charles of Borromeos. and spoke these words: "Don't worry. If you have ten chickens and they steal twenty from you, what do you have? If you have fifteen cows and they steal forty, what do you have?" Thus 1 understand that increased negation established a scale of affirmation of negation. That is how siderial space could become a something. The greater the absence, the greater the presence. The somethingness of absolute absence was the end of the scale. The saint's lesson was well taken, as saint's lessons often are. The poor of the earth were then' wealthy in negation. I was becoming quite poor in terms of my previous life, and this came as a consolation. It also answered the problem of Third World economies, become poorer in order to gain capacity for total change. The impossible gap between the have nots and the haves had been answered by an impossible solution.

The Nicaraguan Revolution posed a new dimension on the development of Latin America. We were taken aback by the fact the poorest of nations had the most advanced revolution. Why? We had not yet accepted our own system in all its implications. Nicaragua was the 



\section{Personas colaboradoras:}

\section{ALEJANDRO VARGAS CARRANZA}

Costarricense. Filólogo, escritor e investigador independiente. Licenciado en Teología por la Universidad Estatal a Distancia (UNED).

alejvargasc2@gmail.com 



\section{Normas PARA PRESENTACIÓN DE ARTÍ́CULOS}

La Revista Siwô’ se publica anualmente. Tiene como objetivo principal, promover el desarrollo de la investigación teológica ecuménica realizada en la Escuela Ecuménica de Ciencias de la Religión y fuera de esta; los artículos discuten temas de realidad social que integran problemáticas costarricenses y latinoamericanas.

Los artículos incluidos son inéditos y originales. En el proceso de revisión se designan pares externos, quienes emiten un veredicto acerca de la calidad del trabajo, el cual luego es analizado por los comités editoriales (UNA y UBL) y los asesores extranjeros.

A continuación, se incluyen las normas para la presentación de artículos que deben ser atendidas por cualquier persona que, siguiendo el objetivo central de la revista, desee plantear un artículo ante el Consejo Editorial de la Escuela Ecuménica de Ciencias de la Religión.

1. Los trabajos deben ser inéditos y originales; no deben estar aprobados para publicarse en otra revista (se enviará una carta al comité editorial donde se dé fe de esto). El autor o la autora adjuntará información personal de contacto: institución, correo electrónico, número telefónico, ciudad.

2. Se privilegia el trabajo teológico ecuménico en lengua castellana. En casos excepcionales, el Consejo Editorial aceptará contribuciones en otras lenguas, principalmente del portugués, inglés y francés. 
3. El artículo debe presentarse en letra Times New Roman, 12 puntos, espacio y medio. Su extensión no debe ser menor de 12 páginas ni mayor de 25 . La división de párrafos debe tener sangría.

4. El artículo debe ser enviado a las siguientes direcciones: revistasiwo@una.ac.cr, revistasiwo@gmail.com o bien, se pueden entregar los impresos en la secretaría de la escuela.

5. Emplee una redacción fluida.

6. Escriba los subtítulos en negrita y de acuerdo con el sistema decimal (ej. 1., 1.1, 1.2).

7. Utilice cursivas (itálicas) para dar énfasis o escribir palabras en otra lengua.

8. Si el texto incluye fuentes del griego o hebreo, indíquelo.

9. Las citas de cuatro líneas o menores van dentro del párrafo; las citas mayores de cuatro líneas van fuera de párrafo. Regule la inclusión de citas.

10. Las fuentes bibliográficas deben seguir el siguiente orden del formato CHICAGO.

a. Libros

i. Libros con un autor

Nota al pie de página

Joseph Campbell. El héroe de las mil caras (México: Fondo de Cultura Económica, 1999), 218-223.

Cita en el texto 
(Campbell 1999, 218-223)

\section{Bibliografía}

Campbell, Joseph. 1999. El héroe de las mil caras. México: Fondo de Cultura Económica.

ii. Libros con dos o más autores

Nota al pie de página

Alberto Bernabé y Ana Isabel Jiménez San Cristóbal, Instructions for the Netherworld: The Orphic Gold Tablets (Leiden/Boston: Brill Academic Pub, 2008), 100.

\section{Cita en el texto}

(Bernabé y Jiménez San Cristóbal 2008, 100)

\section{Bibliografía}

Bernabé, Alberto y Ana Isabel Jiménez San Cristóbal. 2008. Instructions for the Netherworld: The Orphic Gold Tablets. Leiden / Boston: Brill Academic Pub.

Nota: Cuando es un libro con más de tres autores las notas al pie de página deben incluir el nombre del primer autor seguido por "et al." o "y otros". Las dos opciones son correctas. En la bibliografía, usualmente se ponen todos los autores, sin embargo, también se puede utilizar "et al." o "y otros".

\section{iii. Capítulo de un libro con un solo autor}

Nota al pie de página

Antonio Piñero, "Las religiones de "misterios": la búsqueda de la salvación y de la inmortalidad," en Año I. Israel 
y su mundo cuando nació Jesús (España: Laberinto, 2008), 153-172.

Cita en el texto

(Piñero, 2008, 156)

\section{Bibliografía}

Piñero, Antonio. 2008. Las religiones de "misterios": la búsqueda de la salvación y de la inmortalidad. En Año I. Israel y su mundo cuando nació Jesús, 153-172. España, Laberinto.

\section{a. Revistas}

i. Artículos de revistas de difusión

Nota al pie de página

Gabriel Zaid, "La fe en el progreso," Letras Libres, noviembre 2004, 21.

Cita en el texto

(Zaid 2004, 21)

\section{Bibliografía}

Zaid, Gabriel. 2004. La fe en el progreso. Letras Libres, noviembre.

ii. Artículos de revistas académicas

Nota al pie de página

Francisco Diez de Velasco, "Comentarios iconográficos y mitológicos del poema épico Miníada,” Revista Gerión 8 (1990): 73-86. 


\section{Cita en el texto}

(Diez de Velasco 2008)

\section{Bibliografía}

Diez de Velasco, Francisco. 2008. Comentarios iconográficos y mitológicos del poema épico Miníada," Revista Gerión 8 (1990): 73-86.

\section{a. Tesis}

Nota al pie de página

Ana Isabel Jiménez San Cristóbal, "Rituales órficos" (tesis doctoral, Universidad Complutense de Madrid, 2002), 211-223.

\section{Cita en el texto}

(Jiménez San Cristóbal 2002, 211-223)

\section{Bibliografía}

Jiménez San Cristóbal, Ana Isabel. 2002. Rituales órficos. Tesis doctoral., Universidad Complutense de Madrid.

a. Conferencia, ensayo o artículo presentado en un evento académico

Nota al pie de página

Antonio Piñero. "La verdadera historia de la Pasión" (conferencia presentada en las "V Jornadas del Misterio de la Costa Tropical," Granada, España, 18 de octubre al 21 de octubre, 2017). 


\section{Cita en el texto}

(Piñero 2017)

\section{Bibliografía}

Piñero, Antonio. 2017. La verdadera historia de la Pasión.

Conferencia presentada en las V Jornadas del Misterio de la Costa Tropical”, 18 de octubre al 21 de octubre, en Granada, España.

Además de las referencias al pie de página, el artículo debe llevar un apartado final titulado "referencias bibliográficas", donde aparezcan, en orden alfabético, todos los documentos citados.

El artículo debe ordenarse de la siguiente forma:

- Título del trabajo no debe exceder 15 palabras.

- Nombre del autor o la autora.

- $\quad$ Fecha de entrega del material.

- $\quad$ Resumen en castellano, que no exceda las 100 palabras y su respectivo Abstract en inglés.

- Palabras claves en español (un máximo de cinco) y sus respectivas Keywords en inglés.

Introducción, desarrollo de secciones, conclusiones y fuentes consultadas. 



\section{(46) Publicacicama}

Impreso por el Programa de Publicaciones e Impresiones de la Universidad Nacional, en el año 2018.

La edición consta de 100 ejemplares en papel 20 y cartulina barnizable.

0341-18-P.UNA 